\title{
The high-resolution version of TM5-MP for optimized satellite retrievals: description and validation
}

\author{
Jason E. Williams ${ }^{1}$, K. Folkert Boersma ${ }^{1,2}$, Phillipe Le Sager ${ }^{1}$, and Willem W. Verstraeten ${ }^{1,2,3}$ \\ ${ }^{1}$ KNMI, De Bilt, the Netherlands \\ ${ }^{2}$ Meteorology and Air Quality Group, Wageningen University, Wageningen, the Netherlands \\ ${ }^{3}$ KMI, Ukkel, Brussels, Belgium \\ Correspondence to: Jason E. Williams (williams@ knmi.nl)
}

Received: 18 May 2016 - Discussion started: 11 July 2016

Revised: 13 December 2016 - Accepted: 4 January 2017 - Published: 15 February 2017

\begin{abstract}
We provide a comprehensive description of the high-resolution version of the TM5-MP global chemistry transport model, which is to be employed for deriving highly resolved vertical profiles of nitrogen dioxide $\left(\mathrm{NO}_{2}\right)$, formaldehyde $\left(\mathrm{CH}_{2} \mathrm{O}\right)$, and sulfur dioxide $\left(\mathrm{SO}_{2}\right)$ for use in satellite retrievals from platforms such as the Ozone Monitoring Instrument (OMI) and the Sentinel-5 Precursor, and the TROPOspheric Monitoring Instrument (tropOMI). Comparing simulations conducted at horizontal resolutions of $3^{\circ} \times 2^{\circ}$ and $1^{\circ} \times 1^{\circ}$ reveals differences of $\pm 20 \%$ exist in the global seasonal distribution of ${ }^{222} \mathrm{Rn}$, being larger near specific coastal locations and tropical oceans. For tropospheric ozone $\left(\mathrm{O}_{3}\right)$, analysis of the chemical budget terms shows that the impact on globally integrated photolysis rates is rather low, in spite of the higher spatial variability of meteorological data fields from ERA-Interim at $1^{\circ} \times 1^{\circ}$. Surface concentrations of $\mathrm{O}_{3}$ in high- $\mathrm{NO}_{x}$ regions decrease between 5 and $10 \%$ at $1^{\circ} \times 1^{\circ}$ due to a reduction in $\mathrm{NO}_{x}$ recycling terms and an increase in the associated titration term of $\mathrm{O}_{3}$ by $\mathrm{NO}$. At $1^{\circ} \times 1^{\circ}$, the net global stratosphere-troposphere exchange of $\mathrm{O}_{3}$ decreases by $\sim 7 \%$, with an associated shift in the hemispheric gradient. By comparing $\mathrm{NO}, \mathrm{NO}_{2}, \mathrm{HNO}_{3}$ and peroxy-acetyl-nitrate (PAN) profiles against measurement composites, we show that TM5-MP captures the vertical distribution of $\mathrm{NO}_{x}$ and long-lived $\mathrm{NO}_{x}$ reservoirs at background locations, again with modest changes at $1^{\circ} \times 1^{\circ}$. Comparing monthly mean distributions in lightning $\mathrm{NO}_{x}$ and applying ERA-Interim convective mass fluxes, we show that the vertical re-distribution of lightning $\mathrm{NO}_{x}$ changes with enhanced release of $\mathrm{NO}_{x}$ in the upper troposphere. We show that surface mixing ratios in both $\mathrm{NO}$ and $\mathrm{NO}_{2}$ are gener-
\end{abstract}

ally underestimated in both low- and high- $\mathrm{NO}_{x}$ scenarios. For Europe, a negative bias exists for [NO] at the surface across the whole domain, with lower biases at $1^{\circ} \times 1^{\circ}$ at only $\sim 20 \%$ of sites. For $\mathrm{NO}_{2}$, biases are more variable, with lower (higher) biases at $1^{\circ} \times 1^{\circ}$ occurring at $\sim 35 \%$ ( $\sim 20 \%$ ) of sites, with the remainder showing little change. For $\mathrm{CH}_{2} \mathrm{O}$, the impact of higher resolution on the chemical budget terms is rather modest, with changes of less than $5 \%$. The simulated vertical distribution of $\mathrm{CH}_{2} \mathrm{O}$ agrees reasonably well with measurements in pristine locations, although column-integrated values are generally underestimated relative to satellite measurements in polluted regions. For $\mathrm{SO}_{2}$, the performance at $1^{\circ} \times 1^{\circ}$ is principally governed by the quality of the emission inventory, with limited improvements in the site-specific biases, with most showing no significant improvement. For the vertical column, improvements near strong source regions occur which reduce the biases in the integrated column. For remote regions missing biogenic source terms are inferred.

\section{Introduction}

One application of chemistry transport models (CTMs) is to provide accurate vertical and horizontal global distributions of trace gases such as ozone $\left(\mathrm{O}_{3}\right)$, nitrogen dioxide $\left(\mathrm{NO}_{2}\right)$, sulfur dioxide $\left(\mathrm{SO}_{2}\right)$ and formaldehyde $\left(\mathrm{CH}_{2} \mathrm{O}\right)$ that are used as a priori best guesses in the retrievals of tropospheric abundances from instruments mounted on Earth-orbiting satellites such as the Tropospheric Emission Sounder (TES; Worden et al., 2007) Global Ozone Monitoring Experiment (GOME), 
the SCanning Imaging Absorption spectroMeter for Atmospheric CHartographY (SCIAMACHY; De Smedt et al., 2008), the Ozone Monitoring Instrument (OMI; Boersma et al., 2011), and GOME-2 (Valks et al., 2011). To date, although high-resolution regional models have been employed for selected regions such as the US and Europe (e.g. Russell et al., 2011; Zhou et al., 2012; Vinken et al., 2014), at the global scale the CTM resolutions employed are still rather coarse (between 1.1 and $4.0^{\circ}$ in latitude and between 1.1 and $6^{\circ}$ in longitude), resulting in "footprints" which aggregate hundreds of kilometres in area. This has limitations as the resulting total columns are sensitive to topography, surface albedo and the shape of the a priori vertical profiles themselves. Using rather coarse resolution leads to substantial errors in the retrievals (e.g. Boersma et al., 2008; Heckel et al., 2011; Russell et al., 2011) and imposes limitations on capturing the regional-scale variability in short-lived trace gas abundances observed from high-resolution satellite instruments such as the OMI.

This lack of spatial detail is particularly relevant for situations where strong spatio-temporal variability in the vertical distribution of $\mathrm{NO}_{2}, \mathrm{SO}_{2}$, and $\mathrm{CH}_{2} \mathrm{O}$ can be expected. Examples include shipping lanes in the relatively unpolluted marine boundary layer (e.g. Vinken et al., 2014) and coalfired power plant $\mathrm{SO}_{2}$ pollution (e.g. Fioletov et al., 2015). Moreover, during the day the local lifetime and mixing ratios of trace gases such as nitric oxide (NO) and $\mathrm{NO}_{2}$ are critically dependent on a host of variables, e.g. temperature, surface albedo, cloud cover (via photolysis), chemical conversion (i.e. the $\mathrm{NO} / \mathrm{NO}_{2}$ ratio) and the extent of mixing by convective upwelling (i.e. land type) and advective transport. Thus, the information provided for the retrievals is affected by the coarsening of the high-resolution meteorological data used to drive the CTM. Recently, Heckel et al. (2011) demonstrated that there is an associated uncertainty of $\sim 2$ using a priori data from a global CTM rather than a regional CTM, principally due to loss of spatial information. Two other studies focusing on the impact of horizontal resolution on the retrieval of vertical column densities of $\mathrm{NO}_{2}$ suggested that errors of up to $\sim 50 \%$ exist (Yamaji et al., 2014; Lin et al., 2014). This problem becomes accentuated for the next generation of Earth-orbiting satellites such as the Tropospheric Monitoring Instrument (tropOMI), which has a smaller footprint compared to its predecessors (Veefkind et al., 2012). Applications of TM5 include the retrieval of $\mathrm{NO}_{2}, \mathrm{CH}_{2} \mathrm{O}$, and $\mathrm{SO}_{2}$ column densities from the OMI and tropOMI (e.g. van Geffen et al., 2016), where studies related to the influence of horizontal resolution have been limited principally to $\mathrm{NO}_{2}$.

The dominant tropospheric loss terms for $\mathrm{CH}_{2} \mathrm{O}$ are photolysis and scavenging into cloud droplets (wet deposition; Jacob, 2000). Thus the atmospheric lifetime of $\mathrm{CH}_{2} \mathrm{O}$ is highly sensitive to the extent of cloud cover and the vertical profiles of the photolysis rates. A dominant application of $\mathrm{CH}_{2} \mathrm{O}$ retrievals is to provide constraints on tropical and sub- tropical isoprene emission fluxes (e.g. Palmer et al., 2006; Stavrakou et al., 2009; Marais et al., 2012). The resulting emission estimates are highly sensitive to the stoichiometric yield of $\mathrm{CH}_{2} \mathrm{O}$ from isoprene oxidation, the chemical lifetime of $\mathrm{CH}_{2} \mathrm{O}$ and spatial differences in land cover. Other applications include estimating emissions released during biomass burning (BB) episodes (Gonzi et al., 2011), whose spatial location is also smeared via coarsening in TM5-MP. For $\mathrm{SO}_{2}$, which predominantly originates from point sources, an adequate spatial distribution of such sources is crucial for estimating accurate biases in existing emission inventories.

In this paper we provide a comprehensive description of the global, high-resolution $1^{\circ} \times 1^{\circ}$ version of the TM5 CTM tailored for the application of satellite retrievals (hereafter referred to as TM5-MP). In Sect. 2 we give details related to the modifications which have been made to the TM5 model compared to previous versions, the emission inventories employed, updates that have been made to the modified CB05 chemical mechanism, the stratospheric boundary conditions, the photolysis scheme, the heterogeneous conversion and the overall model structure. In Sect. 3 we analyse the impact on convective and advective transport of trace species from the boundary layer (BL) of both increased horizontal resolution and use of ERA-Interim convective mass fluxes, as derived using radon $\left({ }^{222} \mathrm{Rn}\right)$ distributions. In Sect. 4 we investigate the effects on regional and global photolysis frequencies. In Sects. 5-9 we examine the differences in the vertical and horizontal distributions of tropospheric $\mathrm{O}_{3}, \mathrm{NO}_{x}$, lightninginduced $\mathrm{NO}_{x}, \mathrm{~N}$-containing species (i.e. nitric acid $\left(\mathrm{HNO}_{3}\right)$, PAN and lumped organic nitrates (ORGNTR)), $\mathrm{CH}_{2} \mathrm{O}$ and $\mathrm{SO}_{2}$, where we make comparisons against both surface and aircraft measurements to validate mixing ratios. Finally, in Sect. 10, we present our conclusions.

\section{Description of TM5-MP}

Previous versions of TM5 (TM5-chem-v3.0, Huijnen et al., 2010) included a two-way nested zooming option as described by Krol et al. (2005). This option allowed highresolution simulations to be performed over any pre-defined regional domain, with boundary conditions being determined by the global simulation at coarser resolution. Typically, global simulations at $3^{\circ} \times 2^{\circ}$ with zoom regions at $1^{\circ} \times 1^{\circ}$ were performed to alleviate the long runtime of a global $1^{\circ} \times 1^{\circ}$ run. In the new version of TM5 (hereafter referred to as TM5-MP; the massively parallel version), the usage of the Message Passing Interface (MPI) has been totally rewritten. Zoom regions are no longer available, but datasets are distributed along longitudes and latitudes, instead of model levels and tracers. The advantages of that overhaul of domain decomposition are a smaller memory requirement and the possibility of using more processors making global $1^{\circ} \times 1^{\circ}$ simulations feasible in terms of runtime and affordable in terms of computing resources. A TM5-MP global $3^{\circ} \times 2^{\circ}$ 
$\left(1^{\circ} \times 1^{\circ}\right)$ run is $\sim 6(\sim 20)$ times faster than the previous version of TM5 (Huijnen et al., 2010) for similar resources. The following model description pertains to both $3^{\circ} \times 2^{\circ}$ and $1^{\circ} \times 1^{\circ}$ simulations discussed in this paper.

Here we provide a comprehensive description of the modifications and updates introduced into TM5-MP compared to TM5 v3.0 (Huijnen et al., 2010). The model is driven using the ERA-Interim meteorological re-analysis (Dee et al., 2011) and updated every $3 \mathrm{~h}$, with interpolation of fields for the intermediate time periods. Although TM5-MP can adopt all 60 vertical levels provided by the ECMWF ERAInterim reanalysis, we employ 34 vertical levels for this study, with higher resolution in the troposphere and upper troposphere-lower stratosphere (UTLS). Convective mass fluxes and detrainment rates are taken from the ERA-Interim dataset to describe the updraft velocities from the BL into the free troposphere, which replaces the parameterization of Tiedtke (1989) used in previous versions. The vertical diffusion in the free troposphere is calculated according to Louis (1979), and in the BL by the approach of Holtslag and Boville (1993). Diurnal variability in the BL height is determined using the parameterization of Vogelezang and Holtslag (1996). We use the first-order moments scheme with an iterative time step to prevent too much mass being transported out of any particular grid cell according to the preservation of the Courant-Friedrichs-Lewy (CFL) criterion (Bregman et al., 2003), which is especially relevant when reducing the size of grid cells as done here.

The gas-phase chemistry in TM5-MP is described by an expanded version of the modified CB05 chemical mechanism (hereafter mCB05; Williams et al., 2013). We have placed emphasis on updating and expanding the fast $\mathrm{NO}_{x}$ chemistry to account for an accurate partitioning of nitrogen for higher $\mathrm{NO}_{x}$ regimes than those occurring at coarser horizontal resolutions. All reaction rate data are now taken from the latest IUPAC recommendations (sited at http://iupac. pole-ether.fr/; last access June 2016) using updated formulations for third-body collisions, where the rate data for fast $\mathrm{NO}_{x}$ and $\mathrm{CH}_{2} \mathrm{O}$ chemistry are given in Table 1 . This includes the recent update to the formation rate of $\mathrm{HNO}_{3}$ determined by Möllner et al. (2010). The most relevant modifications are that (i) the yield of $\mathrm{CH}_{2} \mathrm{O}$, methanol $\left(\mathrm{CH}_{3} \mathrm{OH}\right)$ and the hydro-peroxy radical $\left(\mathrm{HO}_{2}\right)$ from the self-termination of the methyl-peroxy radical $\left(\mathrm{CH}_{3} \mathrm{O}_{2}\right)$ is increased according to Yarwood et al. (2005), (ii) the direct formation of $\mathrm{CH}_{2} \mathrm{O}$ from the reaction of $\mathrm{CH}_{3} \mathrm{O}_{2}+\mathrm{HO}_{2}$ is added using the temperaturedependent branching ratio defined in Atkinson et al. (2004), (iii) the production of $\mathrm{HNO}_{3}$ during the oxidation of dimethyl sulfide (DMS) by the $\mathrm{NO}_{3}$ radical is now included, (iv) explicit organic peroxy radicals have been introduced as products from the oxidation of propene $\left(\mathrm{C}_{3} \mathrm{H}_{6}\right)$ and propane $\left(\mathrm{C}_{3} \mathrm{H}_{8}\right)$ by $\mathrm{OH}$, which are lost either by the reaction with $\mathrm{NO}$ or $\mathrm{HO}_{2}$ allowing the in situ chemical formation of acetone $\left(\mathrm{CH}_{3} \mathrm{COCH}_{3}\right)$ and higher aldehydes (ALD2), respectively, following the stoichiometry given in Emmons et al. (2010), (v) a second product channel for $\mathrm{N}_{2} \mathrm{O}_{5}$ photolysis is added producing $\mathrm{NO}$, (vi) the formation and photo-dissociation of HONO have been included, (vii) the formation and transport of methyl-peroxy-nitrate $\left(\mathrm{CH}_{3} \mathrm{O}_{2} \mathrm{NO}_{2}\right)$ are also included (Browne et al., 2011), and (vii) modifications to the gasphase chemistry involving $\mathrm{NH}_{3}$ have been introduced following the stoichiometry given in Hauglestaine et al. (2014). This version of the modified CB05 chemical mechanism is hereafter referred to as $\mathrm{mCB} 05 \mathrm{v} 2$.

The calculation of height-resolved photolysis rates ( $J$ values) is performed using a tailored version of the Modified Band Approach (MBA). The implementation and performance of this parameterization in TM5 have been fully described in Williams et al. (2012). For the calculation of the height-resolved actinic fluxes at the seven specific wavelengths used for calculating the $J$ values (these being 205.1, $287.9,302.0,311.0,326.5,385.0$ and $610.0 \mathrm{~nm}$ ), the twostream radiative transfer solver of Zdunkowski et al. (1980) is embedded in TM5-MP. For details regarding the parameterizations used to account for the scattering and absorption introduced by gaseous molecules, aerosols and clouds, the reader is referred to Williams et al. (2012). For aerosols, the climatology of Shettle and Fenn (1979) is included. The calculation of the effective radius $\left(r_{\text {eff }}\right)$ of cloud droplets is now performed using the approach of Martin et al. (1994), where different parameter values are used for over the land and ocean using cloud condensation nuclei concentrations of 40 and 900, respectively. Due to potentially erroneous values at low horizontal resolution, we weight the final $r_{\text {eff }}$ value using the land fraction in each grid cell. We apply limits between 4 and $16 \mu \mathrm{m}$ to the resulting $r_{\text {eff }}$ values. This improves the representation of the scattering component due to cloud droplets used for the calculation of the actinic flux in the lower troposphere (LT; not shown). For the scattering effects from cloud droplets, we subsequently downsize the physical $r_{\text {eff }}$ by $\sim 0.5-2 \mu \mathrm{m}$ to account for the relationship between the optical and physical $r_{\text {eff }}$ values.

For aerosols, an aerosol scheme is available for use within TM5-MP (Aan den Brugh et al., 2011), but we choose not to use it for the purpose of satellite retrievals due to the extra computational expense needed when performing highresolution simulations that would potentially hinder operational use. We acknowledge that the description of aerosols in this study is rather crude, and increasing scattering could have an impact under instances of low cloud coverage. For the application of TM5-MP to satellite retrieval, it is preferable to use any advancements in computational performance on further increases in the horizontal resolution employed. Therefore it is not currently envisaged that a full description of aerosol processes will be included during operational satellite retrievals.

However, heterogeneous conversion processes still need the description of the total reactive surface area density (SAD) from aerosols. In TM5-MP this is assumed as the cumulative value of contributions from sulfate, nitrate, ammo- 
Table 1. Details of the reaction rate data applied for $\mathrm{NO}_{x}$ and nitrogen reservoirs. The $k_{0}$ terms are multiplied by the relevant air density to calculate the correct forward and backward rate constants. The reaction data and stoichiometery are taken from Atkinson et al. (2004) accommodating the latest evaluation at http://iupac.pole-ether.fr.

\begin{tabular}{|c|c|c|}
\hline Reactants & Products & Rate parameters \\
\hline $\mathrm{NO}+\mathrm{O}_{3}$ & $\mathrm{NO}_{2}$ & $3.0 \times 10^{-12} \times \exp (-1500 / T)$ \\
\hline $\mathrm{NO}_{2}+\mathrm{O}_{3}$ & $\mathrm{NO}_{3}$ & $1.4 \times 10^{-13} \times \exp (-2470 / T)$ \\
\hline $\mathrm{NO}+\mathrm{HO}_{2}$ & $\mathrm{NO}_{2}+\mathrm{OH}$ & $3.3 \times 10^{-12} \times \exp (270 / T)$ \\
\hline $\mathrm{NO}+\mathrm{CH}_{3} \mathrm{O}_{2}$ & $\mathrm{CH}_{2} \mathrm{O}+\mathrm{HO}_{2}+\mathrm{NO}_{2}$ & $2.8 \times 10^{-12} \times \exp (300 / T)$ \\
\hline $\mathrm{OH}+\mathrm{NO}_{2}$ & $\mathrm{HNO}_{3}$ & $\begin{array}{l}k_{0}=3.2 \times 10^{-30} \times(300 / T)^{4.5} \\
k_{\infty}=3.0 \times 10^{-11}\end{array}$ \\
\hline $\mathrm{NO}+\mathrm{NO}_{3}$ & $\mathrm{NO}_{2}+\mathrm{NO}_{2}$ & $1.8 \times 10^{-11} \times \exp (110 / T)$ \\
\hline $\mathrm{NO}_{2}+\mathrm{NO}_{3}$ & $\mathrm{~N}_{2} \mathrm{O}_{5}$ & $\begin{array}{l}k_{0}=8.0 \times 10^{-27} \times(300 / T)^{3.5} \\
k_{\infty}=3.0 \times 10^{-11} \times(300 / T)^{1.0}\end{array}$ \\
\hline $\mathrm{N}_{2} \mathrm{O}_{5}+\mathrm{M}$ & $\mathrm{NO}_{2}+\mathrm{NO}_{3}$ & $\begin{array}{l}k_{0}=1.3 \times 10^{-3} \times(300 / T)^{3.5} \times \exp (-11000 / T) \\
k_{\infty}=9.7 \times 10^{14} \times(300 / T)^{-0.1} \times \exp (-11080 / T)\end{array}$ \\
\hline $\mathrm{HO}_{2}+\mathrm{NO}_{2}$ & $\mathrm{HNO}_{4}$ & $\begin{array}{l}k_{0}=1.4 \times 10^{-31} \times(300 / T)^{3.1} \\
k_{\infty}=4.0 \times 10^{-12}\end{array}$ \\
\hline $\mathrm{HNO}_{4}+\mathrm{M}$ & $\mathrm{HO}_{2}+\mathrm{NO}_{2}$ & $\begin{array}{l}k_{0}=4.1 \times 10^{-5} \times \exp (-10650 / T) \\
k_{\infty}=6.0 \times 10^{15} \times \exp (-11170 / T)\end{array}$ \\
\hline $\mathrm{OH}+\mathrm{HNO}_{4}$ & $\mathrm{NO}_{2}$ & $1.3 \times 10^{-12} \times \exp (380 / T)$ \\
\hline $\mathrm{OH}+\mathrm{NO}+\mathrm{M}$ & HONO & $\begin{array}{l}k_{0}=7.0 \times 10^{-31} \times(300 / T)^{4.4} \\
k_{\infty}=3.6 \times 10^{-11} \times(300 / T)^{0.1}\end{array}$ \\
\hline $\mathrm{HONO}+h v$ & $\mathrm{OH}+\mathrm{NO}$ & \\
\hline $\mathrm{OH}+\mathrm{HONO}$ & $\mathrm{NO}_{2}$ & $2.5 \times 10^{-12} \times \exp (260 / T)$ \\
\hline $\mathrm{NO}_{2}+\mathrm{CH}_{3} \mathrm{C}(\mathrm{O}) \mathrm{O}_{2}$ & PAN & $\begin{array}{l}k_{0}=3.28 \times 10^{-28} \times(300 / T)^{6.87} \\
k_{\infty}=1.125 \times 10^{-11} \times(300 / T)^{1.105}\end{array}$ \\
\hline PAN & $\mathrm{NO}_{2}+\mathrm{CH}_{3} \mathrm{C}(\mathrm{O}) \mathrm{O}_{2}$ & $\begin{array}{l}k_{0}=1.1 \times 10^{-5} \times \exp (-10100 / T) \\
k_{\infty}=1.9 \times 10^{17} \times \exp (-14100 / T)\end{array}$ \\
\hline $\mathrm{PAN}+h v$ & $\mathrm{CH}_{3} \mathrm{C}(\mathrm{O}) \mathrm{O}_{2}+\mathrm{NO}_{2} \mathrm{CH}_{3} \mathrm{O}_{2}+\mathrm{NO}_{3}$ & \\
\hline $\mathrm{CH}_{3} \mathrm{O}_{2}+\mathrm{NO}_{2}$ & $\mathrm{CH}_{3} \mathrm{O}_{2} \mathrm{NO}_{2}$ & $\begin{array}{l}k_{0}=2.5 \times 10^{-30} \times(300 / T) \\
k_{\infty}=1.8 \times 10^{-11}\end{array}$ \\
\hline $\mathrm{CH}_{3} \mathrm{O}_{2} \mathrm{NO}_{2}$ & $\mathrm{CH}_{3} \mathrm{O}_{2}+\mathrm{NO}_{2}$ & $\begin{array}{l}k_{0}=9.0 \times 10^{-5} \times \exp (-9690 / T) \\
k_{\infty}=1.1 \times 10^{16} \times \exp (-10560 / T)\end{array}$ \\
\hline $\mathrm{NO}_{3}+\mathrm{HO}_{2}$ & $\mathrm{HNO}_{3}$ & $4.0 \times 10^{-12}$ \\
\hline
\end{tabular}

nium and methane sulfonic acid as calculated by the EQuilibrium Simplified Aerosol Model (EQSAM) approach (Metzger et al., 2002); thus, the secondary organic aerosol component is not included. The distribution of these aerosol species is calculated online and coupled to the respective gaseous precursors. The density of each aerosol type $\left(1.7 \mathrm{~g} \mathrm{~cm}^{-3}\right)$ and $r_{\text {eff }}$ (of between 0.18 and $0.2 \mu \mathrm{m}$ ) is prescribed as in Huijnen et al. (2014). Swelling at higher relative humidities (>70\%) is crudely accounted for by increasing $r_{\text {eff }}$ between 0.25 and $0.27 \mu \mathrm{m}$. The contributions due to sea salt, black carbon and organic carbon towards heterogeneous loss are not accounted for. Temperature-dependent gas-phase diffusion coefficients $\left(D_{\mathrm{g}}\right)$ are used in the derivation of the pseudo first-order heterogeneous rate constants based on the theory of Schwartz (1986).

For $\mathrm{N}_{2} \mathrm{O}_{5}$, the uptake coefficient $(\gamma)$ is calculated using the parameterization of Evans and Jacob (2005), and is therefore dependent on both temperature and relative humidity.
Once a surface reaction with $\mathrm{H}_{2} \mathrm{O}$ occurs, 2 molecules of $\mathrm{HNO}_{3}$ are formed. No uptake on cirrus particles is included for $\mathrm{HNO}_{3}$, which can lead to de-nitrification of the upper troposphere (Lawrence and Crutzen, 1998; von Kuhlmann and Lawrence, 2006). For $\mathrm{HO}_{2}$ we adopt a fixed $\gamma_{\mathrm{HO}_{2}}=0.06$ across all aerosol types as taken from Abbatt et al. (2012), and for $\mathrm{NO}_{3}$ we adopt a fixed $\gamma_{\mathrm{NO}_{3}}=10^{-3}$ as recommended by Jacob (2000). For $\mathrm{HO}_{2}$, heterogeneous conversion forms 0.5 molecules of hydrogen peroxide $\left(\mathrm{H}_{2} \mathrm{O}_{2}\right)$, whereas for $\mathrm{NO}_{3}$ it forms 1 molecule of $\mathrm{HNO}_{3}$ following Emmons et al. (2010). For the SAD associated with cloud droplets we

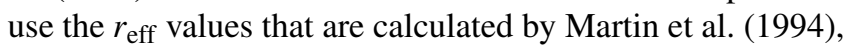
thus maintaining consistency between the size of the cloud droplets used for the scattering component in the calculation of $J$ values and heterogeneous loss rates on the clouds. By using the ECMWF cloud fraction for each respective grid cell, we assume that instantaneous mixing throughout the 
grid cell does not occur, in order to avoid exaggerated conversion rates on cloud surfaces.

As TM5-MP contains no explicit stratospheric chemistry, we apply constraints above the tropopause to ensure realistic stratosphere-troposphere exchange (STE) of $\mathrm{O}_{3}$ and for constraining the incoming radiation reaching the troposphere needed for the MBA (Williams et al., 2012). For stratospheric $\mathrm{O}_{3}$, we use total column values derived from the assimilation of satellite observations as provided in the improved version of the Multi-Sensor Re-analysis (MSR, van der A et al., 2010), which is vertically distributed according to the climatology of Fortuin and Kelder (1998). Three distinct zonal bands are used for nudging the stratospheric $\mathrm{O}_{3}$ fields, these being $30^{\circ} \mathrm{S}-30^{\circ} \mathrm{N}, 30-66^{\circ} \mathrm{S} / \mathrm{N}$ and $>66^{\circ} \mathrm{S} / \mathrm{N}$, where nudging occurs at pressure levels $<45 \mathrm{hPa},<95 \mathrm{hPa}$ and $<120 \mathrm{hPa}$, with relaxation times of $2.5,3$ and 4 days, respectively.

For stratospheric $\mathrm{CH}_{4}$ we use the monthly 2-D climatological fields provided by Grooß and Russell (2005), with the nudging heights and relaxation times being identical to those used for stratospheric $\mathrm{O}_{3}$. For stratospheric $\mathrm{CO}$ and $\mathrm{HNO}_{3}$ we constrain mixing ratios by using monthly mean ratios of $\mathrm{CO} / \mathrm{O}_{3}$ (Dupuy et al., 2004) and $\mathrm{HNO}_{3} / \mathrm{O}_{3}$ (Jégou et al., 2008; Urban et al., 2009) based on the latitudinal climatologies derived from ODIN observations using data for 2003/2004 (CO) and 2001-2009 $\left(\mathrm{HNO}_{3}\right)$. In order to avoid jumps in the nudging constraints between months, we gradually change between ratios using the total monthly difference/number of days in the month. These ratios are applied using the monthly mean stratospheric $\mathrm{O}_{3}$ distribution in TM5-MP, which is constrained by the MSR dataset (van der A et al., 2010). For both species, model fields are nudged at 5.5, 10 and $28 \mathrm{hPa}$ using relaxation times of 5, 10 and 60 days, respectively. Previous versions of TM5 used a $\mathrm{HNO}_{3}$ climatology from the UARS MLS instrument and applied nudging constraints at $10 \mathrm{hPa}$ only (Huijnen et al., 2010).

For our study on the impact of horizontal resolution on the performance of TM5-MP, we present simulations for the year 2006, which has been used for previous benchmarking studies (Huijnen et al., 2010; Williams et al., 2012). We use a 1-year spin-up from the same initial conditions, where the initial conditions are representative of the state-of-theatmosphere for January 2005 taken from a previous simulation (see Zeng et al., 2015). The model is run using $34 \mathrm{lev-}$ els, as it will be used operationally for satellite retrievals, with details of the pressure levels being given in Huijnen et al. (2010).

\subsection{Emission inventories}

All emission inventories applied in TM5-MP are yearspecific, meaning that the year-to-year variability in emission fluxes due to changes in anthropogenic activity, biogenic activity and burning extent is taken into account. For the anthropogenic emission of $\mathrm{NO}_{x}, \mathrm{CO}, \mathrm{SO}_{2}, \mathrm{NH}_{3}$ and nonmethane volatile organic compounds (NMVOC), we adopt the MACCity emission estimates described in Granier et al. (2011). The lack of sector-specific information complicates the use of daily cycles for e.g. the road transport component, where a bi-sinusoidal distribution could be applied, peaking in the morning and late afternoon to represent variability in traffic volume. Aircraft emissions are included only for NO, using a homogenous hourly flux estimate not related to regional flight times. For volcanic $\mathrm{SO}_{2}$ emissions, the estimated emission flux has been scaled up to $10 \mathrm{Tg} \mathrm{S} \mathrm{yr}^{-1}$ based on Halmer et al. (2002). For the biogenic component, where available we use the CLM-MEGANv2.1 emission inventories produced for the Southern Hemispheric Multi-model Intercomparison Project (SHMIP) as described in Zeng et al. (2015), with the missing trace species (e.g. ethane, propane, higher organics) coming from alternative MEGAN simulations as outlined in Sindelarova et al. (2014). A diurnal cycle is imposed on the isoprene emissions and introduced into the first $\sim 50 \mathrm{~m}$ between $20^{\circ} \mathrm{S}$ and $20^{\circ} \mathrm{N}$, whereas for other latitudes a continuous daily flux is applied. The BB emissions are taken from the monthly estimates provided by the GFEDv3 inventory (van der Werf et al., 2010) and latitude-dependent injection heights and a tropical burning cycle are implemented following Huijnen et al. (2010). All emission inventories are provided on a $0.5^{\circ} \times 0.5^{\circ}$ resolution and subsequently coarsened onto the horizontal resolution employed in any simulation. In TM5-MP all $\mathrm{NO}_{x}$ emissions are introduced as NO, rather than specifying a fraction that is emitted directly as $\mathrm{NO}_{2}$ (Carslaw and Beevers, 2005). Global $\mathrm{NO}_{x}$ emissions for the year 2006 total $49 \mathrm{Tg} \mathrm{N} \mathrm{yr}^{-1}$ (including lightning). Other notable species include CO $\left(1081 \mathrm{TgCO} \mathrm{yr}^{-1}\right), \mathrm{SO}_{2}\left(117 \mathrm{Tg} \mathrm{S} \mathrm{yr}^{-1}\right), \mathrm{CH}_{2} \mathrm{O}$ $\left(13.5 \mathrm{Tg} \mathrm{C} \mathrm{yr}^{-1}\right)$ and isoprene $\left(510 \mathrm{Tg} \mathrm{C} \mathrm{yr}^{-1}\right)$. An overview of the global and zonal emission terms used in the simulations analysed here is given in Table 3.

For lightning $\mathrm{NO}_{x}$ we use the parameterization which uses convective precipitation fields (Meijer et al., 2001) and constrain the annual global emission term at $\sim 6 \mathrm{Tg} \mathrm{N} \mathrm{yr}^{-1}$. This uses the convective flux values, meaning that re-scaling of the nudging term was necessary in order to achieve similar total lightning $\mathrm{NO}_{x}$ emissions across simulations. An example of the resulting horizontal distributions in lightning $\mathrm{NO}_{x}$ at $\sim 400 \mathrm{hPa}$ for the tropics for both horizontal resolutions is shown in the top panel of Fig. S1a in the Supplement. Although the spatial variability increases at $1^{\circ} \times 1^{\circ}$, the global distribution remains essentially the same, where the constraints on annual lightning $\mathrm{NO}_{x}$ emissions homogenize the total emission flux between resolutions. One other factor affecting the vertical distribution of lightning $\mathrm{NO}_{x}$ emissions is the convective parameterization which is used. The lower panels of Fig. S1a show that, at this altitude, the Tiedke (1989) approach increases the $\mathrm{NO}_{x}$ emissions at this level by $\sim 14 \%$, accompanied by a significant re-distribution between regions (cf. the Southern Hemisphere $(\mathrm{SH})$ below 
Table 2. Details of updates made to the reaction data and stoichiometry of the modified CB05 chemical mechanism for other reactions. Data are taken from the following: (1) Atkinson et al. (2004) accommodating the latest evaluation at http://iupac.pole-ether.fr, (2) a branching ratio $(R)$ equal to $1 /(1+498 . \times \exp (-1160 . / T)$, (3) Yarwood et al. (2005), (4) Sander et al. (2011), (5) Atkinson et al. (2006), (6) Emmons et al. (2010), (7) Hauglustaine et al. (2014), (8) a rate assumed equal to the $\mathrm{NH}_{2}$ analogue, (9) assumed to be equal to $\mathrm{HNO}_{4}$ after $\mathrm{Browne}$ et al. (2011), and (10) $E$ is an estimated value.

\begin{tabular}{|c|c|c|c|}
\hline Reactants & Products & Rate expression & Ref. \\
\hline $\mathrm{CH}_{3} \mathrm{O}_{2}+\mathrm{HO}_{2}$ & $\mathrm{CH}_{3} \mathrm{OOH}$ & $3.8 \times 10^{-13} \times \exp (750 / T) \times R$ & $(1),(2)$ \\
\hline $\mathrm{CH}_{3} \mathrm{O}_{2}+\mathrm{HO}_{2}$ & $\mathrm{CH}_{2} \mathrm{O}$ & $3.8 \times 10^{-13} \times \exp (750 / T) \times(1-R)$ & $(1),(2)$ \\
\hline $\mathrm{CH}_{3} \mathrm{O}_{2}+\mathrm{CH}_{3} \mathrm{O}_{2}$ & $1.37 \mathrm{CH}_{2} \mathrm{O}+0.74 \mathrm{HO}_{2}+0.63 \mathrm{CH}_{3} \mathrm{OH}$ & $9.5 \times 10^{-14} \times \exp (390 / T)$ & $(3),(4)$ \\
\hline $\mathrm{OH}+\mathrm{C}_{3} \mathrm{H}_{8}$ & i- $\mathrm{C}_{3} \mathrm{H}_{7} \mathrm{O}_{2}$ & $7.6 \times 10^{-12} \times \exp (-585 / T)$ & $(5),(6)$ \\
\hline $\mathrm{NO}+\mathrm{IC}_{3} \mathrm{H}_{7} \mathrm{O}_{2}$ & $0.82 \mathrm{CH}_{3} \mathrm{COCH}_{3}+\mathrm{HO}_{2}+0.27 \mathrm{ALD} 2+\mathrm{NO}_{2}$ & $4.2 \times 10^{-12} \times \exp (180 / T)$ & (6) \\
\hline $\mathrm{HO}_{2}+\mathrm{IC}_{3} \mathrm{H}_{7} \mathrm{O}_{2}$ & $\mathrm{ROOH}$ & $7.5 \times 10^{-13} \times \exp (700 / T)$ & (6) \\
\hline $\mathrm{OH}+\mathrm{C}_{3} \mathrm{H}_{6}$ & $\mathrm{C}_{3} \mathrm{H}_{6} \mathrm{O}_{2}$ & $\begin{array}{l}k_{0}=8.0 \times 10^{-27} \times(-300 / T)^{3.5} \\
k_{\infty}=3.0 \times 10^{-11} \times(-300 / T)^{1.0}\end{array}$ & $(5),(6)$ \\
\hline $\mathrm{NO}_{3}+\mathrm{C}_{5} \mathrm{H}_{8}$ & $\begin{array}{l}\text { 0.2ISPD }+\mathrm{XO}_{2}+0.8 \mathrm{HO}_{2}+ \\
0.8 \mathrm{ORGNTR}+0.8 \mathrm{ALD} 2+ \\
\text { 2.4 PAR }+0.2 \mathrm{NO}_{2}\end{array}$ & $2.95 \times 10^{-12} \times \exp (465 / T)$ & (5) \\
\hline $\mathrm{NO}+\mathrm{C}_{3} \mathrm{H}_{6} \mathrm{O}_{2}$ & $\begin{array}{l}\mathrm{ALD} 2+\mathrm{CH}_{2} \mathrm{O}+ \\
\mathrm{HO}_{2}+\mathrm{NO}_{2}\end{array}$ & $4.2 \times 10^{-12} \times \exp (180 / T)$ & (6) \\
\hline $\mathrm{HO}_{2}+\mathrm{C}_{3} \mathrm{H}_{6} \mathrm{O}_{2}$ & $\mathrm{ROOH}$ & $7.5 \times 10^{-13} \times \exp (700 / T)$ & (6) \\
\hline $\mathrm{NO}_{3}+\mathrm{DMS}$ & $\mathrm{SO}_{2}+\mathrm{HNO}_{3}$ & $1.9 \times 10^{-13} \times \exp (520 / T)$ & (1) \\
\hline $\mathrm{NH}_{2}+\mathrm{OH}$ & & $3.4 \times 10^{-11}$ & $(E)$ \\
\hline $\mathrm{NH}_{2}+\mathrm{HO}_{2}$ & $\mathrm{NH}_{3}$ & $3.4 \times 10^{-11}$ & $(4),(7)$ \\
\hline $\mathrm{NH}_{2}+\mathrm{O}_{3}$ & $\mathrm{NH}_{2} \mathrm{O}_{2}$ & $4.3 \times 10^{-12} \times \exp (-930 / T)$ & $(4),(7)$ \\
\hline $\mathrm{NH}_{2}+\mathrm{O}_{2}$ & $\mathrm{NO}$ & $6.0 \times 10^{-21}$ & $(1),(7)$ \\
\hline $\mathrm{NH}_{2} \mathrm{O}_{2}+\mathrm{NO}$ & $\mathrm{NH}_{2}+\mathrm{NO}_{2}$ & $4.0 \times 10^{-12} \times \exp (450 / T)$ & $(7),(8)$ \\
\hline $\mathrm{NH}_{2} \mathrm{O}_{2}+\mathrm{O}_{3}$ & $\mathrm{NH}_{2}$ & $4.3 \times 10^{-12} \times \exp (-930 / T)$ & $(7),(8)$ \\
\hline $\mathrm{NH}_{2} \mathrm{O}_{2}+\mathrm{HO}_{2}$ & $\mathrm{NH}_{2}$ & $3.4 \times 10^{-11}$ & (8) \\
\hline $\mathrm{CH}_{3} \mathrm{O}_{2} \mathrm{NO}_{2}+h v$ & $\mathrm{CH}_{3} \mathrm{O}_{2}+\mathrm{NO}_{2}$ & & (9) \\
\hline $\mathrm{CH}_{3} \mathrm{O}_{2} \mathrm{NO}_{2}+h v$ & $\mathrm{CH}_{2} \mathrm{O}+\mathrm{HO}_{2}+\mathrm{NO}_{3}$ & & (9) \\
\hline $\mathrm{HO}_{2}+$ aero & $0.5 \mathrm{H}_{2} \mathrm{O}_{2}$ & & \\
\hline $\mathrm{NO}_{3}+$ aero & $\mathrm{HNO}_{3}$ & & (6) \\
\hline
\end{tabular}

$30^{\circ} \mathrm{S}$ and an significant increase in the tropical component in the Tiedke simulation). However, this is altitude-dependent, where the absolute differences in the vertical distribution in the monthly $\mathrm{NO}_{x}$ emissions for a selection of latitudes are shown in Fig. S1b. Here comparisons are shown both over the continents (e.g. $50.5^{\circ} \mathrm{N}$ ) and the oceans (e.g. $59.5^{\circ} \mathrm{S}$ ). Although the differences in the integrated monthly global emission $\mathrm{NO}_{x}$ flux are only around $\sim 1-2 \%$, the temporal and vertical distribution can be quite different between convective schemes. Profiles show that in the upper troposphere ERA-Interim consistently results in higher $\mathrm{NO}_{x}$ emissions around $300 \mathrm{hPa}$, especially for July.

Latitudinal constraints on $\mathrm{CH}_{4}$ global distributions are applied using the methodology given in Bândǎ et al. (2015) with a 3-day relaxation time. We also introduce similar constraints based on the appropriate surface measurements for $\mathrm{H}_{2}$ in order to account for the latitudinal gradient and variability across seasons, which replaces the fixed global value of $550 \mathrm{ppb}$ used in previous versions. Finally, for radon
$\left(\mathrm{Rn}^{222}\right)$ emissions we apply the estimates of Schery (2004), whose global distribution is given in Zhang et al. (2011).

\subsection{Observations}

Although the performance of mCB05 in TM5 v3.0 has been validated for selected $\mathrm{NMVOC}, \mathrm{O}_{3}, \mathrm{CH}_{2} \mathrm{O}, \mathrm{CO}$ and $\mathrm{NO}_{y}$ in both hemispheres (Williams et al., 2013, 2014; Fisher et al., 2015; Zeng et al., 2015), the significant changes made to both the chemical scheme and the rate parameters in $\mathrm{mCB} 05 \mathrm{v} 2$ necessitate independent validation at both $3^{\circ} \times 2^{\circ}$ and $1^{\circ} \times 1^{\circ}$. We choose a range of ground-based and airborne measurements taken at diverse locations during the year 2006, representing different chemical regimes. Here we briefly describe the observations utilized for this purpose.

For validation of simulated surface concentrations we use measurements of gaseous $\mathrm{O}_{3}, \mathrm{NO}, \mathrm{NO}_{2}, \mathrm{HNO}_{3}$ and $\mathrm{SO}_{2}$ available from the European Monitoring and Evaluation program (EMEP, www.emep.int), where we exploit measurements taken at various background sites in Norway, Finland, the Netherlands, Belgium, Poland, the Czech Republic, Ger- 
Table 3. The zonally segregated emission totals introduced into TM5-MP for the year 2006. All organic hydrocarbons are given in $\mathrm{TgC} \mathrm{yr}^{-1}$, except for $\mathrm{CO}\left(\mathrm{TgCO} \mathrm{yr}^{-1}\right), \mathrm{CH}_{2} \mathrm{O}\left(\mathrm{Tg} \mathrm{CH}_{2} \mathrm{O} \mathrm{yr}^{-1}\right)$ and $\mathrm{CH}_{3} \mathrm{OH}\left(\mathrm{TgCH}_{3} \mathrm{OHyr}^{-1}\right)$. All $\mathrm{NO}_{x}$ emissions are introduced as $\mathrm{NO}\left(\mathrm{TgNyr}^{-1}\right)$. For $\mathrm{SO}_{2}$ emission totals are given as $\mathrm{Tg} \mathrm{SO}_{2} \mathrm{yr}^{-1}$ and for $\mathrm{NH}_{3}$ as $\mathrm{Tg} \mathrm{NH}_{3} \mathrm{yr}^{-1}$. No direct emissions occur for $\mathrm{HNO}_{3}, \mathrm{PAN}$, ORGNTR, $\mathrm{HONO}, \mathrm{N}_{2} \mathrm{O}_{5}, \mathrm{NO}_{2}, \mathrm{CH}_{3} \mathrm{O}_{2} \mathrm{NO}_{2}$ or $\mathrm{O}_{3}$.

\begin{tabular}{|c|c|c|c|c|}
\hline Species $\operatorname{Tg~yr}^{-1}$ & Global & $30-90^{\circ} \mathrm{S}$ & $30^{\circ} \mathrm{S}-30^{\circ} \mathrm{N}$ & $30-90^{\circ} \mathrm{N}$ \\
\hline $\mathrm{CO}$ & 1081.0 & 24.4 & 755.1 & 301.27 \\
\hline $\mathrm{NO}_{x}($ as $\mathrm{N})$ & 49.0 & 1.5 & 24.0 & 23.6 \\
\hline $\mathrm{SO}_{2}$ & 117.0 & 3.0 & 49.2 & 64.3 \\
\hline DMS (as S) & 19.2 & 6.7 & 9.3 & 3.2 \\
\hline $\mathrm{NH}_{3}$ & 56.6 & 3.1 & 27.9 & 25.6 \\
\hline $\mathrm{CH}_{2} \mathrm{O}$ & 13.5 & 0.3 & 10.5 & 2.7 \\
\hline PAR & 34.1 & 0.7 & 18.5 & 14.9 \\
\hline OLE & 22.4 & 0.9 & 16.6 & 4.9 \\
\hline ALD2 & 13.4 & 0.4 & 11.2 & 1.8 \\
\hline $\mathrm{CH}_{3} \mathrm{CHCHO}$ & 2.2 & 0.0 & 1.2 & 1.0 \\
\hline $\mathrm{CH}_{3} \mathrm{OH}$ & 100.7 & 3.3 & 82.5 & 14.9 \\
\hline $\mathrm{CH}_{3} \mathrm{CH}_{2} \mathrm{OH}$ & 70.4 & 2.8 & 52.6 & 15.1 \\
\hline $\mathrm{C}_{2} \mathrm{H}_{4}$ & 25.9 & 1.0 & 19.0 & 5.9 \\
\hline $\mathrm{C}_{2} \mathrm{H}_{6}$ & 6.1 & 0.3 & 5.3 & 1.5 \\
\hline $\mathrm{C}_{3} \mathrm{H}_{8}$ & 5.6 & 0.4 & 3.6 & 1.6 \\
\hline $\mathrm{C}_{3} \mathrm{H}_{6}$ & 19.6 & 0.9 & 14.8 & 3.9 \\
\hline $\mathrm{CH}_{3} \mathrm{COCH}_{3}$ & 27.4 & 0.8 & 22.0 & 4.6 \\
\hline $\mathrm{HCOOH}$ & 1.8 & 0.0 & 1.5 & 0.3 \\
\hline $\mathrm{CH}_{3} \mathrm{COOH}$ & 7.1 & 0.1 & 6.0 & 1.0 \\
\hline $\mathrm{C}_{5} \mathrm{H}_{8}$ & 510.0 & 23.2 & 441.9 & 45.0 \\
\hline $\mathrm{C}_{10} \mathrm{H}_{16}$ & 85.4 & 2.3 & 70.2 & 12.9 \\
\hline
\end{tabular}

many, Great Britain, Spain, Slovakia, Italy and Portugal. The number of sites used for comparisons of trace species other than $\mathrm{O}_{3}$ is smaller due to data availability. For the model composites we extract data from 3-hourly instantaneous output in order to assemble both the weekly and monthly mean values from the simulations. For the weekly comparisons of $\mathrm{NO}_{2}$ and $\mathrm{SO}_{2}$ we use values extracted at 13:00 local time, close to the overpass time of the OMI instrument (e.g. Boersma et al., 2008). The selected stations allow validation of the seasonality for both rural regions (FI37) and urban regions (NL09), where we include identical stations where possible for both species. For $\mathrm{HNO}_{3}$ we assemble the weekly values from the daily averages.

Measured $\left[\mathrm{O}_{3}\right]$ in the EMEP network is obtained using UV monitors (Aas et al., 2001). For all species, spatial interpolation of model data is performed, accounting for the height of the measurement station and by weighting using the distance of the station from the surrounding grid cells. The wide range of measurement sites chosen ensures that both background and polluted cases are assessed.

For validating the vertical distribution of relevant trace species such as $\mathrm{O}_{3}, \mathrm{SO}_{2}$ and $\mathrm{CH}_{2} \mathrm{O}$, we use measurements by the DC- 8 aircraft during the Intercontinental Chemical Transport Experiment B (INTEX-B; Singh et al., 2009) that took place between March and May 2006. Observations of a host of co-located nitrogen-containing species are avail- able (namely $\mathrm{NO}, \mathrm{NO}_{2}, \mathrm{PAN}$ and $\mathrm{HNO}_{3}$ ). These flights were conducted over a wide region, and we use all 3 months of measurements. Each month sampled a different region representing different meteorological conditions and local emission sources, namely, the Gulf of Mexico $\left(90-100^{\circ} \mathrm{W}, 15-\right.$ $\left.30^{\circ} \mathrm{N}\right)$, the remote Pacific $\left(176-140^{\circ} \mathrm{W}, 20-45^{\circ} \mathrm{N}\right)$ and to the south and west of Alaska over the ocean $\left(160-135^{\circ} \mathrm{W}\right.$, $\left.20-60^{\circ} \mathrm{N}\right)$. Measurements cover altitudes up to $10.5 \mathrm{~km}$, and we bin the values with respect to pressure using $50 \mathrm{hPa}$ bins or less in the LT. We interpolated 3-hourly output against measurements for each respective day, similar to the comparisons performed in previous evaluations of TM5 (e.g. Huijnen et al., 2010), but we segregate our comparisons into the three distinct regions. For details relating to the location of each flight the reader is referred to the campaign overview of Singh et al. (2009).

For tropospheric $\mathrm{O}_{3}$, we supplement the INTEX-B comparisons with measurements taken over more polluted regions as part of the Measurement of Ozone, water vapour, carbon monoxide and nitrogen oxides by Airbus In-service aircraft initiative (MOZAIC; Thouret et al., 1998). We aggregate the measurements as seasonal means for DecemberJanuary-February (DJF) and June-July-August (JJA) in order to provide a robust number of samples for each location. Here we choose to use profiles representative of the northern mid-latitudes, namely, London $\left(0.2^{\circ} \mathrm{W}, 51.2^{\circ} \mathrm{N}\right)$, Vienna $\left(16.5^{\circ} \mathrm{E}, 48.1^{\circ} \mathrm{N}\right)$, Washington $\left(77.5^{\circ} \mathrm{W}, 38.9^{\circ} \mathrm{N}\right)$, Portland $\left(122.6^{\circ} \mathrm{W}, 45.6^{\circ} \mathrm{N}\right)$, Shanghai $\left(121.8^{\circ} \mathrm{E}, 31.2^{\circ} \mathrm{N}\right)$ and Tokyo $\left(140.4^{\circ} \mathrm{E}, 35.8^{\circ} \mathrm{N}\right)$.

We also make comparisons of $\mathrm{O}_{3}, \mathrm{NO}, \mathrm{NO}_{2}$, selected $\mathrm{N}$ reservoir species, $\mathrm{SO}_{2}$ and $\mathrm{CH}_{2} \mathrm{O}$ profiles using measurements made aboard the NOAA WP-3D aircraft as part of the Second Texas Air Quality Study (TexAQS II; Parrish et al., 2009), which was conducted over the Texas seaboard during September and October 2006. This allows the assessment of TM5-MP over a region with higher NMVOC emissions and industrial activity. These measurements were typically sampled at altitudes below $500 \mathrm{hPa}$; therefore, no measurements in the UTLS are available from this campaign.

\section{The effect on atmospheric transport}

Here we analyse the differences in convective transport out of the BL by analysing the vertical and horizontal distribution of ${ }^{222} \mathrm{Rn}$, which is a diagnostic typically used for assessing the differences in transport in CTMs (e.g. Jacob et al., 1997). ${ }^{222} \mathrm{Rn}$ is emitted at a steady rate and exhibits a half-life of $\sim 3.8$ days, which is long enough to be transported from the BL into the FT due to chemical passivity, with loss via wet scavenging and dry deposition being negligible. Therefore, it acts as an ideal tracer to assess differences in convective transport from the surface out of the BL. The representation of BL dynamics for TM5-MP has recently been assessed at $1^{\circ} \times 1^{\circ}$ using ${ }^{222} \mathrm{Rn}$ distributions for both the Tiedtke (1989) 
Table 4. The tropospheric chemical budget terms and burden for $\mathrm{O}_{3}$ during 2006 for the $1^{\circ} \times 1^{\circ}$ simulation, with all quantities being given in $\mathrm{Tg} \mathrm{O}_{3} \mathrm{yr}^{-1}$. The associated percentage changes are given when comparing against the $3^{\circ} \times 2^{\circ}$ simulation $\left(\right.$ equal to $\left(1^{\circ} \times 1^{\circ}\right)-$ $\left.\left(3^{\circ} \times 2^{\circ}\right) / 3^{\circ} \times 2^{\circ}\right)$. The definition of the chemical tropopause and the calculation of the STE are calculated using the methodology outlined in Stevenson et al. (2006). The stratospheric nudging term refers to total change in the mass of $\mathrm{O}_{3}$ in the stratospheric column when constraining zonal distributions to observational values from the MSR (Huijnen et al., 2010). The contributions to each term from the SH extra-tropics/tropics/NH extra-tropics regions (defined as $90-30^{\circ} \mathrm{S} / 30^{\circ} \mathrm{S}-30^{\circ} \mathrm{N} / 30-90^{\circ} \mathrm{N}$ ) are provided.

\begin{tabular}{lrrrrrrrr}
\hline Term & Global & $\%$ & SH & $\%$ & Tropics & $\%$ & NH & $\%$ \\
\hline Net STE & 579 & -6.7 & & & & & & \\
Strat. nudging & 1440 & -0.7 & -224 & 2.8 & 1615 & - & 49 & 5.8 \\
Trop. chem. prod. & 5532 & -1.9 & 389 & -2.2 & 3938 & -3.5 & 1206 & -2.2 \\
Trop. chem. loss & 5162 & -2.4 & 440 & -1.0 & 3869 & -2.5 & 853 & -2.8 \\
$\mathrm{BO}_{3}$ & 378 & -2.0 & 72 & 1.7 & 203 & -2.3 & 104 & -3.4 \\
${\text { Strat. } \mathrm{BO}_{3}}^{80}$ & -2.0 & 23 & 9.1 & 38 & -6.5 & 24 & -2.0 \\
\hline Deposition & 949 & 0.8 & 115 & 0.6 & 465 & - & 369 & 1.9 \\
$\mathrm{O}_{3} \mathrm{~S}$ deposition & 97 & 5.0 & 19 & 7.5 & 37 & -1.2 & 42 & 10.0 \\
\hline
\end{tabular}

scheme and when adopting convective mass transport values from the ERA-Interim meteorological data (Koffi et al., 2016).

Figure 1 shows seasonal mean horizontal global distributions of ${ }^{222} \mathrm{Rn}$ for DJF and JJA in the $1^{\circ} \times 1^{\circ}$ simulation averaged between 800 and $900 \mathrm{hPa}$ (i.e. sampling the LT). Also shown are the associated percentage differences against the re-binned $3^{\circ} \times 2^{\circ}{ }^{222} \mathrm{Rn}$ distribution, allowing a direct comparison. Resolution-dependent differences result from the cumulative effects of the use of higher-resolution mass fluxes from the ERA-Interim meteorological data for describing convective activity and the more accurate temporal distribution of regional ${ }^{222} \mathrm{Rn}$ emissions at $1^{\circ} \times 1^{\circ}$. In general it can be seen that seasonal differences of $\pm 20 \%$ exist, typically with increases over continents and decreases over oceans in the $1^{\circ} \times 1^{\circ}$ simulations. Maximum differences of $>60 \%$ occur near selected coastal regions (California, western Africa, Madagascar) or in outflow regions such as off South America and Africa, where differences exhibit a strong seasonal dependency. This is due to the large differences in convective strength due to the variability in heating rates, and thus temperatures, between land and ocean (e.g. Sutton et al., 2007).

A comparison of the ratio of the monthly mean ${ }^{222} \mathrm{Rn}$ profiles $\left(1^{\circ} \times 1^{\circ} / 3^{\circ} \times 2^{\circ}\right)$ extracted above for selected European cities for January (black) and July (blue) 2006 is shown in Fig. S3 in the Supplement. The typical tropospheric profile of ${ }^{222} \mathrm{Rn}$ exhibits an exponential decay from the LT to the FT (not shown). In order to homogenize the emission flux in the comparison, we coarsen the $1^{\circ} \times 1^{\circ}$ data onto the $3^{\circ} \times 2^{\circ}$ grid by averaging the six individual values into a representative mean column. The extent of the changes in the vertical distribution of ${ }^{222} \mathrm{Rn}$ is somewhat site-specific, meaning an in-depth analysis is beyond the scope of this paper. In summary, the $1^{\circ} \times 1^{\circ}$ simulation generally provides stronger convective activity for January, with the main impact occurring below $700 \mathrm{hPa}$ (e.g. London and Paris). The changes in ${ }^{222} \mathrm{Rn}$ in the LT range between 2 and $10 \%$ (i.e. ratios of 0.9 to 1.1 ), implying both weaker and stronger convective transport, depending on changes in location (e.g. orography and land type). The impact at Berlin is larger than e.g. Barcelona, which shows that, surprisingly, the inclusion of a large ocean fraction (with weaker convective mixing) in the $3^{\circ} \times 2^{\circ}$ cell does not seem to introduce dominating effects. Recently Koffi et al. (2016) have shown that comparisons of ${ }^{222} \mathrm{Rn}$ at coastal sites in Europe at $1^{\circ} \times 1^{\circ}$ exhibit significant discrepancies compared to more continental stations. For July the changes in the vertical distribution extend into the FT up to $500 \mathrm{hPa}$, although changes in the upper FT have a significant component due to changes in long-range transport. The magnitudes of the changes are similar to those exhibited during January, although maybe of the opposite sign (e.g. Rome). Thus the influence on e.g. $\mathrm{NO}_{2}, \mathrm{CH}_{2} \mathrm{O}$ and $\mathrm{SO}_{2}$ a priori vertical profiles will be non-negligible and diverse.

For the tropical cities located in regions where convective mixing is stronger, the corresponding differences between resolutions can reach $\pm 20 \%$, especially near the surface (e.g. Caracas and Karachi). There is a site-specific seasonal dependency in the magnitude of the changes related to the regional land characteristics (e.g. Lagos versus Kuala Lumpur) and the extent of the ocean within any particular grid cell. Thus, differences in a priori vertical profiles of trace gases using a resolution of $1^{\circ} \times 1^{\circ}$ can be considerable compared to those provided at a $3^{\circ} \times 2^{\circ}$ resolution.

We also show ratios of profiles from $1^{\circ} \times 1^{\circ}$ simulations using the convective scheme of Tiedtke (1989) against those using the convective mass fluxes from the ERA-Interim meteorological dataset (Fig. S4), defined as $\operatorname{ERA}\left(1^{\circ} \times 1^{\circ}\right) /$ Tiedtke $\left(1^{\circ} \times 1^{\circ}\right)$. For this comparison no daily averaging is employed, with ${ }^{222} \mathrm{Rn}$ profiles extracted from 3-hourly instantaneous sampling, with the profiles shown being interpolated directly above urban conurbations (with high trace gas emissions). The ratios show that the 

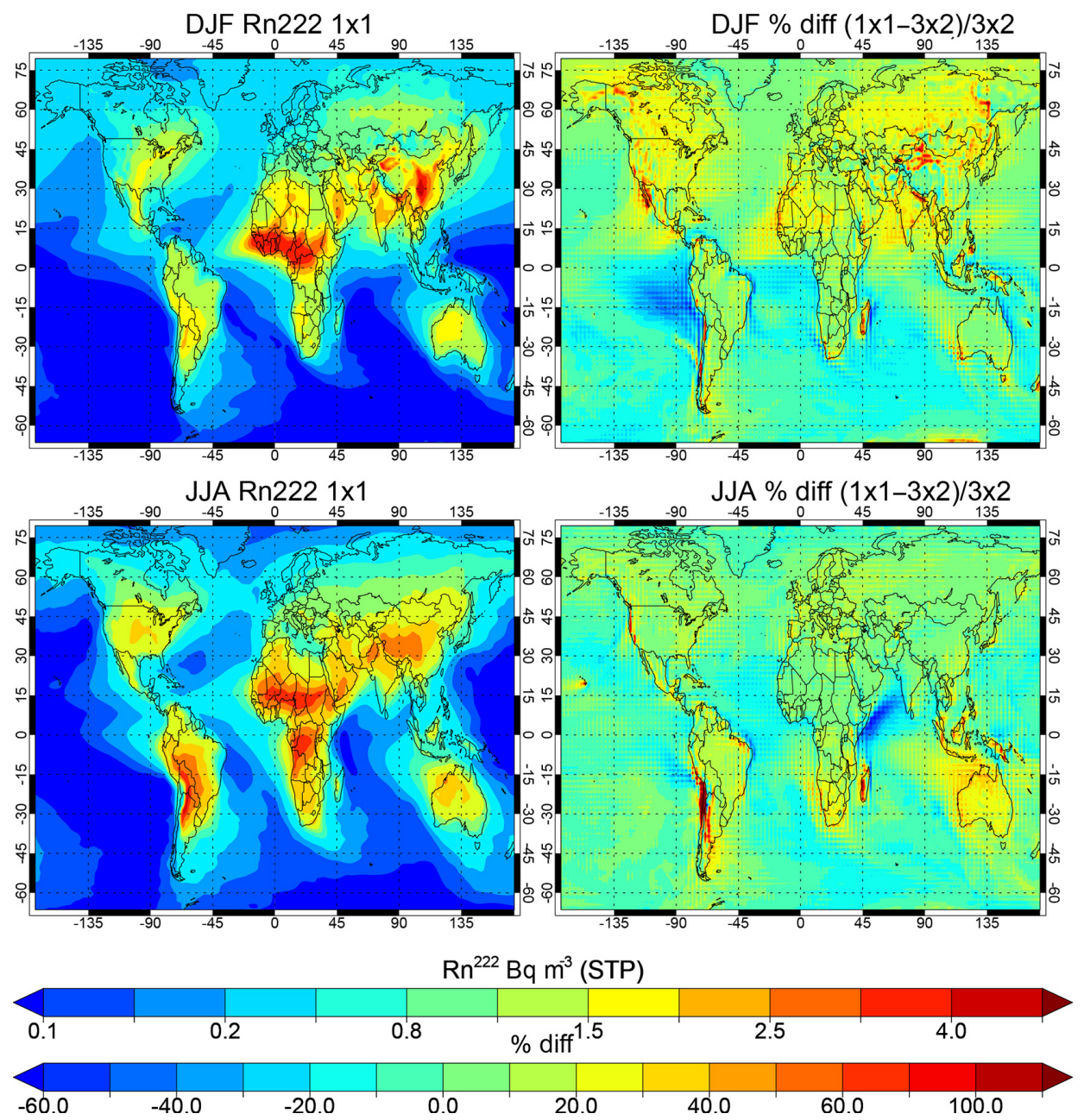

Figure 1. The seasonal distributions of $\mathrm{Rn}^{222}$ averaged between 800 and $900 \mathrm{hPa}$ for DJF (top) and JJA (bottom) for the $3^{\circ} \times 2^{\circ}($ left) and $1^{\circ} \times 1^{\circ}$ (right) simulations, with the associated percentage differences when compared against the $3^{\circ} \times 2^{\circ}$ simulation.

significant differences exist, with the convective mass fluxes from ERA-Interim being somewhat weaker than those calculated online using Tiedtke (1989), i.e. the ratio is typically less than 1 , especially during July. In the recent study by Koffi et al. (2016) performed at $1^{\circ} \times 1^{\circ}$ for the European domain, there was no appreciable improvement in the correlation coefficients when distributions of ${ }^{222} \mathrm{Rn}$ were compared against measurements, resulting in no strong conclusion about which of the parameterizations results in better atmospheric transport.

\section{The impact on tropospheric photolysis frequencies}

The changes in the spatio-temporal distribution of tropospheric clouds and surface albedo have the potential to alter the incident flux of photolysing light reaching the surface, and thus photochemical production and destruction terms. When present, clouds dominate the integrated optical density in the tropospheric column. TM5-MP uses a random overlap method for determining the impact of clouds on actinic flux, which is weighted by cloud cover (Williams et al., 2012). Comparing seasonal mean cloud coverage for DJF and JJA (Fig. S5), we show that there are significant increases in the fractional cloud cover (fcc) at $1^{\circ} \times 1^{\circ}$, resulting in fcc values ranging between 0.1 and 0.8 (cf. $0.1-0.5$ for $3^{\circ} \times 2^{\circ}$ ). Moreover, the definition of tropical equatorial cloud systems becomes much more defined and there are significant differences in the cloud distributions around the western coast of South America. For DJF, the largest changes occur at high latitudes over the tundra and oceans, but correspond to lowintensity incident radiation due to the polar winter. For the $\mathrm{SH}$, the seasonal fcc increases significantly, which will potentially impose effects on Antarctic oxidative capacity (see Sect. 5). For JJA, most increases in fcc do not occur directly above high- $\mathrm{NO}_{x}$ sources, but rather over the oceans. This limits the impact on the lifetime of chemical precursors (e.g. $\mathrm{NO}_{2}$ ) as discussed in Sect. 6. Examining similar plots for surface albedo (not shown) reveals that the maximum differ- 
ences (increases at $1^{\circ} \times 1^{\circ}$ ) again occur in the polar regions under low temperatures related to sea ice and snow coverage, typically during polar winters. For mid-latitudes and tropics, although differences in the absolute albedo value can be significant $( \pm 50 \%)$, values are typically below 0.1 , which will contribute to the perturbations in the final $J$ value tropospheric profiles as discussed below. The monthly mean comparisons in surface $J$ values provided in Fig. S6 show that any differences in instantaneous cloud cover are moderated to the order of a few percent when looking at longer periods.

The similarity in the monthly mean photolysis frequencies for $\mathrm{O}_{3}$ and $\mathrm{NO}_{2}$ across resolutions (hereafter denoted $J_{\mathrm{O}_{3}}$ and $J_{\mathrm{NO}_{2}}$, respectively) are shown in Fig. S6 of the Supplement. Comparisons of the monthly mean $J_{\mathrm{O}_{3}}$ and $J_{\mathrm{NO}_{2}}$ values are shown at five different locations identical to those shown in Williams et al. (2012). For $J_{\mathrm{O}_{3}}$ the impact of increasing resolution is limited to a few percent in the monthly mean values, even for regions which have high surface albedo. At the global scale this leads to a reduction of $\sim 2 \%$ in the total mass of $\mathrm{O}_{3}$ photolysed (not shown). For $J_{\mathrm{NO}_{2}}$, the corresponding differences become more appreciable, with $1^{\circ} \times 1^{\circ}$ exhibiting $\sim 5-10 \%$ higher values at high northern latitudes (associated with locations with high$\mathrm{NO}_{x}$ regimes). Focusing on $J_{\mathrm{NO}_{2}}$ and comparing seasonal mean values near the surface show that very similar largescale spatial patterns occur for both simulations at the global scale (cf. Fig. S7). The highest $J_{\mathrm{NO}_{2}}$ values occur over the tropical oceans and high-altitude regions (e.g. Nepal), with a latitudinal shift related to seasonal changes in daylight hours. Although a more regional fine structure can be seen at $1^{\circ} \times 1^{\circ}$ (e.g. the south-western US and south-western China for DJF), these seasonal averages show that the small perturbations in $J_{\mathrm{NO}_{2}}$ shown in Fig. S6 extend to the global scale, leading to only modest changes in the tropospheric lifetime of $\mathrm{NO}_{2}$ (see Sect. 6).

Comparisons of monthly mean vertical profiles of $J_{\mathrm{O}_{3}}$ and $J_{\mathrm{NO}_{2}}$ as sampled over selected tropical cities are shown in Fig. S8a and b, respectively, in the Supplement. Here no averaging is performed towards an identical horizontal resolution; therefore, values are representative of the $J$ values directly above the selected urban centres. The $J_{\mathrm{O}_{3}}$ profiles are affected to a larger extent than the $J_{\mathrm{NO}_{2}}$ profiles, due to the characteristic absorption spectra of each species which make $J_{\mathrm{O}_{3}}$ more sensitive to the additional scattering introduced due to clouds. Profiles over Dubai act as a proxy for clear-sky conditions, where values of unity exist in the residual of $J_{\mathrm{O}_{3}}$ and $J_{\mathrm{NO}_{2}}$ calculated through most of the column. The small difference at the surface is due to changes in the surface albedo between resolutions, with Dubai being situated on the coast, meaning that a sharp horizontal gradient exists in surface albedo. For other cities, the largest perturbations occur away from the surface (e.g. Jakarta, Nairobi and Lagos) around the altitude where tropospheric clouds are most abundant. There are typically changes of between \pm 5 and $10 \%$ in the monthly mean profiles. The changes in
$J_{\mathrm{NO}_{2}}$ reflect those simulated for $J_{\mathrm{O}_{3}}$, with somewhat smaller perturbations.

\section{Implications for oxidative capacity and tropospheric $\mathrm{O}_{3}$}

The partitioning of reactive $\mathrm{N}$ between the short- and longlived chemical N-reservoirs included in TM5-MP depends on the oxidative capacity simulated for the troposphere via competition between the various different radicals (i.e. $\mathrm{OH}$, $\mathrm{CH}_{3} \mathrm{C}(\mathrm{O}) \mathrm{O}_{2}, \mathrm{NO}_{3}$ and $\left.\mathrm{CH}_{3} \mathrm{O}_{2}\right)$. Therefore, changes to the distribution and resident mixing ratios of tropospheric $\mathrm{O}_{3}$ subsequently impose changes in the fractional composition of the $\mathrm{NO}_{y}$ budget (Olszyna et al., 1994) and also the efficiency of the $\mathrm{NO}_{x}$ recycling terms by altering the chain length (Lelieveld et al., 2002). In this section we analyse the global and zonal chemical budget terms for tropospheric $\mathrm{O}_{3}$ to highlight the inter-hemispheric differences which occur (i.e. under low- and high- $\mathrm{NO}_{x}$ environments). An overview of the resulting near-surface global distribution of tropospheric $\mathrm{O}_{3}$ for May 2006 is shown in Fig. 3, which also includes the location of the regional comparisons presented below in a larger global context. In general, the pattern of minimum and maximum mixing ratios in $\mathrm{O}_{3}$ occurs in similar locations, with the long-range transport component being more clearly defined in the $1^{\circ} \times 1^{\circ}$ simulation. There is a distinct latitudinal gradient in $\mathrm{O}_{3}$ mixing ratios imposed by the global distribution of $\mathrm{NO}_{x}$ emissions.

Table 4 provides the zonally segregated chemical budget terms for tropospheric $\mathrm{O}_{3}$, from which the global component due to STE can be determined by closing the budget terms following the methodology given in Stevenson et al. (2006). The chemical tropopause calculated for $3^{\circ} \times 2^{\circ}$ is applied for the analysis of $1^{\circ} \times 1^{\circ}$ budget terms to ensure that a valid comparison is performed, (i.e. the same mass of air is accounted for). For computational efficiency the budget terms are aggregated in $10^{\circ}$ latitudinal bins for each vertical level and summed across all longitudes, providing the cumulative latitudinal terms.

The most significant change with resolution concerns STE. By using a dedicated tagged stratospheric $\mathrm{O}_{3}$ tracer (which only undergoes photo-chemical destruction and deposition in the troposphere; hereafter denoted as $\mathrm{O}_{3} \mathrm{~S}$ ), changes in the zonal mean STE can be determined. The stratospheric burden of $\mathrm{O}_{3}\left(\mathrm{BO}_{3}\right.$ (strat)) exhibits a strong hemispheric gradient with much more downwelling occurring in the Northern Hemisphere $(\mathrm{NH})$, peaking during boreal springtime. At the global scale the STE exchange is $579 \mathrm{Tg} \mathrm{O}_{3} \mathrm{yr}^{-1}$, which agrees well with the multi-model mean for STE of $556 \pm 154 \mathrm{Tg} \mathrm{O}_{3} \mathrm{yr}^{-1}$ in Stevenson et al. (2006), with observational estimates being $\sim 550 \pm 140 \mathrm{Tg} \mathrm{O}_{3} \mathrm{yr}^{-1}$ (Olsen et al., 2001). The $\sim 7 \%$ reduction of STE at $1^{\circ} \times 1^{\circ}$ is encouraging considering that previous studies using TM5 have concluded that STE in TM5 at $3^{\circ} \times 2^{\circ}$ was biased high com- 

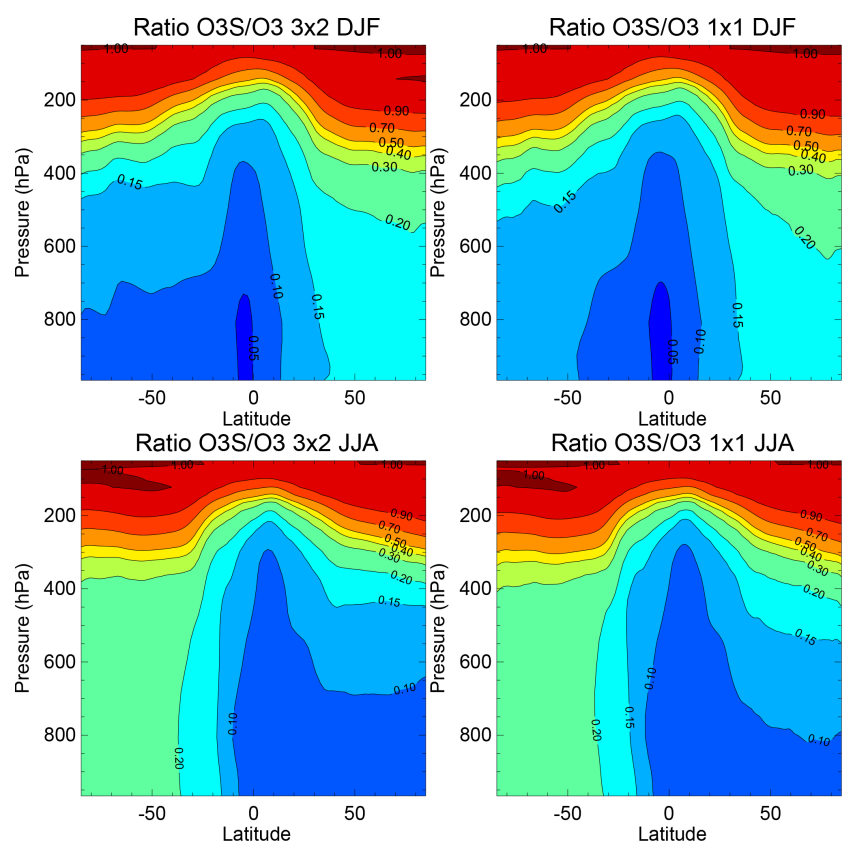

Figure 2. Zonal mean seasonal distribution of the TM5-MP $\mathrm{O}_{3} \mathrm{~S} / \mathrm{O}_{3}$ ratio for the $3^{\circ} \times 2^{\circ}$ (left) and $1^{\circ} \times 1^{\circ}$ (right) simulations.

pared to STE inferred from TES and MLS satellite observations (Verstraeten et al., 2015). The increase in STE in the $\mathrm{SH}$, with an associated decrease in the $\mathrm{NH}$ (see below), implies that there is a shift in circulation patterns at $1^{\circ} \times 1^{\circ}$ even though $\mathrm{BO}_{3}$ (strat) remains essentially unchanged. Previous studies have shown that in order to resolve the correct spatial and temporal stratosphere-troposphere flux, high resolution is required both in the horizontal and the vertical gridding (e.g. Meloen et al., 2002). The NH STE diagnosed with TM5-MP is an order of magnitude smaller than estimates derived in a CTM study also conducted at a $1^{\circ} \times 1^{\circ}$ resolution (Tang et al., 2011; $\sim 200 \mathrm{Tg} \mathrm{O}_{3} \mathrm{yr}^{-1}$ ), which identified deep convection as important for STE. Here we use a different vertical grid and meteorological dataset to drive TM5-MP, both of which affect the ability to capture an accurate STE flux (Meloen et al., 2002). For the $1^{\circ} \times 1^{\circ}$ simulation using the Tiedtke scheme, there is a further reduction in the STE component of $21 \mathrm{Tg} \mathrm{O}_{3} \mathrm{yr}^{-1}$, resulting in an STE component almost identical to the multi-model mean in Stevenson et al. (2006).

The zonal seasonal means of the fraction of $\mathrm{O}_{3} \mathrm{~S}$ to $\mathrm{O}_{3}$ $\left(\mathrm{O}_{3} \mathrm{~S} / \mathrm{O}_{3}\right)$ for both simulations are shown in Fig. 2 for DJF and JJA. There is a clear seasonal zonal shift in the fractional contribution due to the $\mathrm{O}_{3}$ transported downwards from the stratosphere exhibiting a longer lifetime in the winter hemisphere, reflecting a lower photochemical destruction rate. At $1^{\circ} \times 1^{\circ}$ the largest increase in STE occurs in the SH during JJA. Here $\sim 20-25 \%$ of tropospheric $\mathrm{O}_{3}$ is transported down from the stratosphere. Comparing the 0.2 contour for the NH mid-troposphere shows significant changes, extend- ing further down towards the surface during boreal wintertime, leading to the higher total mass of $\mathrm{O}_{3} \mathrm{~S}$ in the troposphere. The extent of nudging towards the MSR climatology is essentially constant across simulations (cf. Table 4). Interestingly, less $\mathrm{O}_{3} \mathrm{~S}$ reaches the surface in the tropics at $1^{\circ} \times 1^{\circ}$ due to the enhanced chemical destruction term in the free troposphere. Approximately $10 \%$ of the global deposition term for $\mathrm{O}_{3}$ is associated with $\mathrm{O}_{3}$ that originates from the stratosphere at $1^{\circ} \times 1^{\circ}\left(\mathrm{cf} . \sim 5 \%\right.$ at $\left.3^{\circ} \times 2^{\circ}\right)$. For the $\mathrm{NH}$, this contributes to the simulated increase in deposition of $\sim 9 \%$.

For tropospheric $\mathrm{O}_{3}$ there are similarities that occur between the $\mathrm{NH}$, tropics and $\mathrm{SH}$, i.e. high- and low- $\mathrm{NO}_{x}$ scenarios, resulting in a cumulative decrease in $\mathrm{O}_{3}$ production of $\sim 2-4 \%$ across zones. For the chemical loss terms there is a modest decrease of $\sim 3 \%(\sim 2 \%)$ in the $\mathrm{NH}(\mathrm{SH})$ reflective of the changes discussed for $J_{\mathrm{O}_{3}}$, which acts as the primary destruction term. Therefore, in the $\mathrm{SH}$ the significant differences shown for fcc do not significantly impose a lower photochemical destruction term on the annual tropospheric $\mathrm{O}_{3}$ budget. There is a zonal gradient in the tropospheric burden of $\mathrm{O}_{3}\left(\mathrm{BO}_{3}\right)$ following the zonal gradient in $\mathrm{NO}_{x}$ emissions (cf. Fig. 3). Comparing terms shows that $\mathrm{BO}_{3}$ decreases at $1^{\circ} \times 1^{\circ}$ by a few percent at the global scale $\left(\sim 7 \mathrm{TgO}_{3}\right)$, making a rather small impact on oxidative capacity. This is of the same order of magnitude as that found in previous studies concerned with horizontal resolution (e.g. Wild and Prather, 2006). Interestingly, changes in the deposition flux of $\mathrm{O}_{3}$ are rather small, even though there is a larger amount of variability in the land surfaces and a better-resolved landsea contrast at $1^{\circ} \times 1^{\circ}$, although differences in regional deposition fluxes can be more significant. Multi-model intercomparisons of surface deposition terms across models have shown previous versions of TM5 to be at the low end of the model spread in terms of $\mathrm{O}_{3}$ (Hardacre et al., 2015), suggesting that the surface deposition flux should be increased by $\sim 10 \%$ in TM5-MP towards the multi-model mean value. This can be partly attributed to the large uncertainty which exists related to the loss of $\mathrm{O}_{3}$ to the ocean (Hardacre et al., 2015).

Figure 4 shows comparisons of simulated and observed mass mixing ratios of surface $\mathrm{O}_{3}$ at EMEP sites across Europe (www.emep.int; Aas et al., 2001), with stations chosen to cover a range of latitudes. Previous comparisons using mCB05 have revealed high biases in surface $\mathrm{O}_{3}$, especially during boreal summertime (Williams et al., 2013). These high biases originate from cumulative effects associated with the accuracy of the emission inventories, the convective and turbulent mixing component, the underestimation of the scattering and absorption of photolysing light due to aerosols and the chemical mechanism that is employed. For the emission component it should be noted that even at $1^{\circ} \times 1^{\circ}$ coarsening is performed, where emission inventories are typically supplied at $0.5^{\circ} \times 0.5^{\circ}$ resolution. The seasonal cycle in surface $\mathrm{O}_{3}$ is captured to a large degree, and the high bias exhibited by the model is generally reduced by $\sim 2-5 \mathrm{ppb}$ (or $\sim 20 \%$ ) 

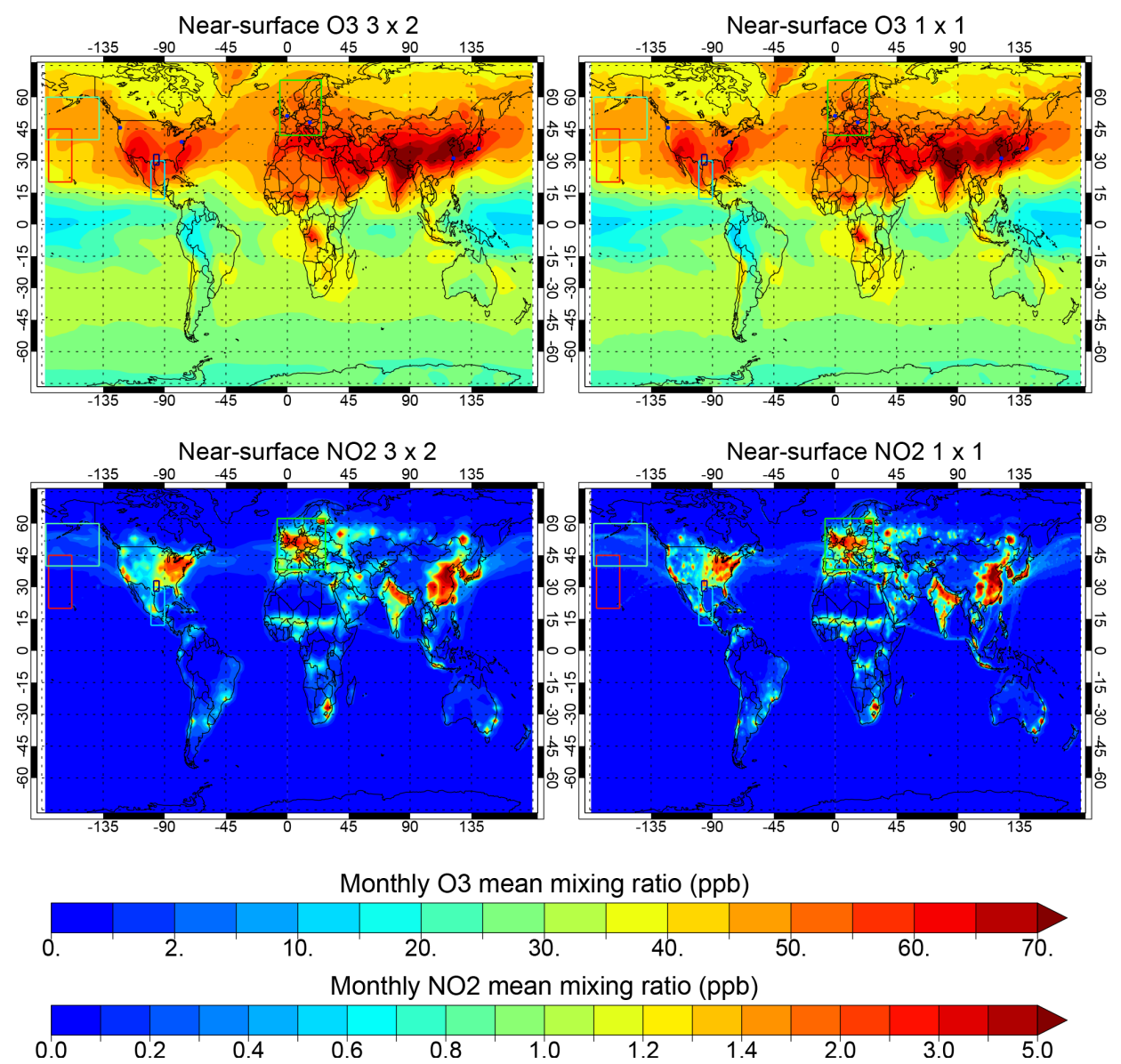

Figure 3. The near-surface distribution in tropospheric $\mathrm{O}_{3}$ (top) and $\mathrm{NO}_{2}$ (bottom) for May 2006 from the $3^{\circ} \times 2^{\circ}$ (left) and $1^{\circ} \times 1^{\circ}$ (right) TM5-MP simulations. The blue points represent the location of the MOZAIC airports used for comparisons. Also shown are the locations of the INTEXB and Texas-AQSII measurement campaigns, and the extent of the EMEP network in the European domain, used for the validation of the resulting $\mathrm{O}_{3}$ and $\mathrm{NO}_{2}$ distributions.

at $1^{\circ} \times 1^{\circ}$. This is associated with perturbations in the $\mathrm{NO}_{x}$ recycling terms, chemical titration by $\mathrm{NO}$, changes to the turbulent diffusion and convective mixing out of the BL. The improvement in biases is largest during boreal summertime, associated with the shorter chain length of the $\mathrm{NO}_{x}$ recycling term during boreal wintertime. However, there is still a significant monthly mean bias in both simulations when compared against observations throughout the year, especially for locations impacted by a large anthropogenic $\mathrm{NO}_{x}$ source. This is partly due to the low $\mathrm{NO} / \mathrm{NO}_{2}$ ratio as discussed in Sect. 6 below.

Comparing vertical profiles from composites assembled from the MOZAIC measurements for DJF and JJA (Figs. S9a and S8b, respectively), INTEX-B (Singh et al., 2009; Fig. S10) and TexAQS II (Parrish et al., 2009; Fig. S11) show consistently that differences are small between simulations across regions, and typically mimic those which occur at the surface. There is a general positive bias of $\sim 20-40 \%$ in mixing ratios exhibited across all comparisons, although the variability in the vertical gradients across regions is cap- tured rather well. Such positive biases have consequences for both the $\mathrm{NO}_{x}$ recycling terms and $\mathrm{HNO}_{3}$ formation discussed in the sections below.

\section{Implications for the distribution of $\mathrm{NO}$ and $\mathrm{NO}_{2}$}

Table 5 provides the zonally segregated annual $\mathrm{NO}_{x}$ recycling terms involving the main peroxy radicals and the direct titration term involving $\mathrm{NO}$ for the $1^{\circ} \times 1^{\circ}$ simulation. The conversion rate of $\mathrm{NO}$ back into $\mathrm{NO}_{2}$ decreases by $\sim 2$ $3 \%$ across zones as a consequence of an associated increase in the titration term and re-partitioning of $\mathrm{N}$ into long-lived reservoir species (see below). For the titration term involving NO, although the globally integrated flux remains relatively constant, there is contrasting behaviour for the two most important zones (TR, NH), which exhibit a lower and higher titration term, respectively. It has been shown that for regions such as Europe the increased titration results in lower surface 

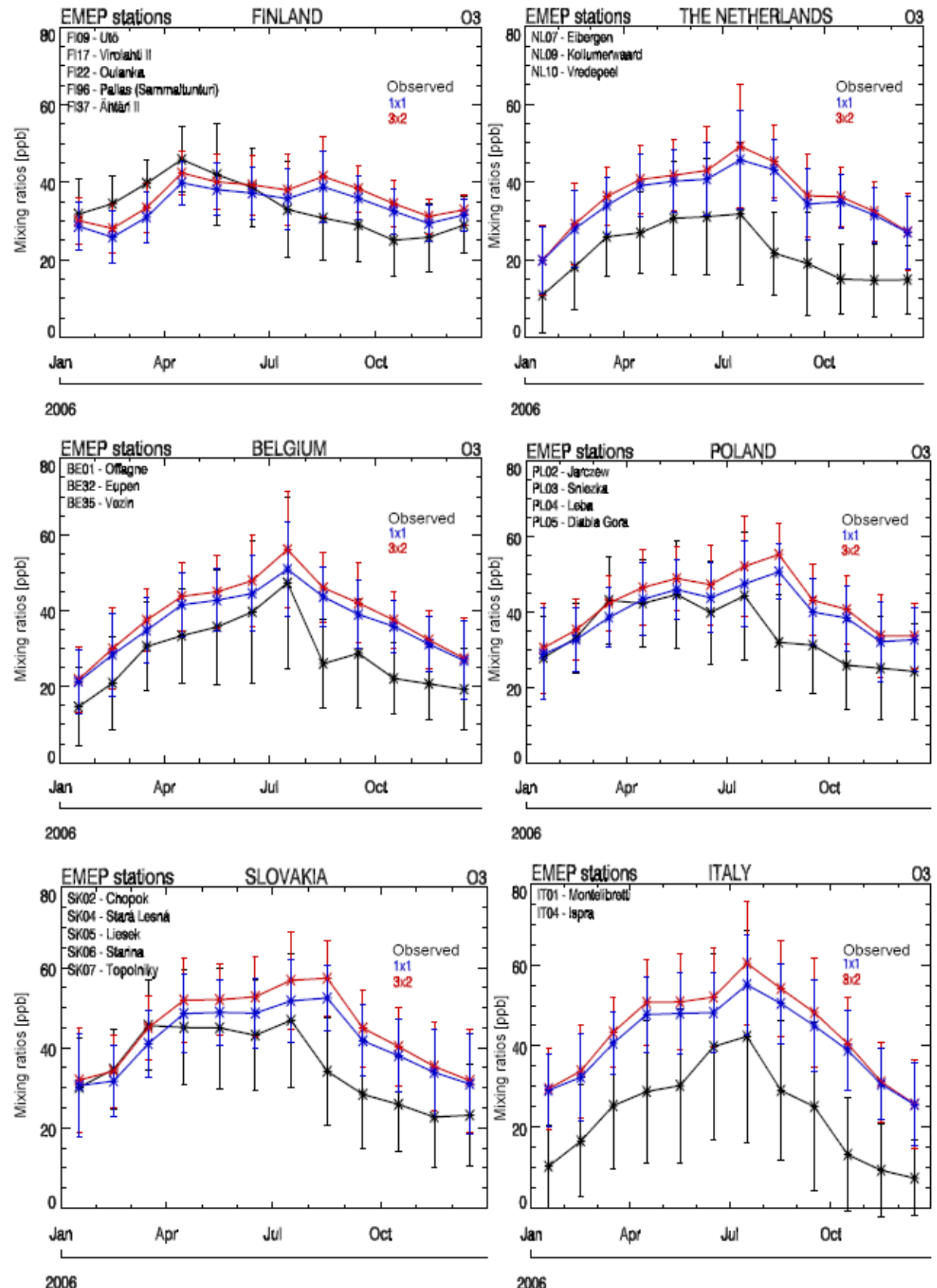

Figure 4. Comparisons of the seasonal variability in TM5-MP mass mixing ratios for surface $\mathrm{O}_{3}$ against composites of measurements taken across the EMEP monitoring network for 2006. Both the co-located TM5-MP $3^{\circ} \times 2^{\circ}$ and $1^{\circ} \times 1^{\circ}$ monthly mean values are shown, along with the $1 \sigma$ variability for Finland, the Netherlands, Belgium, Poland, Slovakia and Italy. Individual stations that are aggregated are given in the panels.

$\mathrm{O}_{3}$ mixing ratios (cf. Fig. 4), improving the boreal summertime high bias at the surface.

Important model uncertainties include the quality of the MACCity $\mathrm{NO}_{x}$ emission inventory, the lifetime of $\mathrm{NO}_{2}$ simulated in TM5, $\mathrm{BL}$ mixing and the $\mathrm{NO}_{x}$ recycling term via the chemical titration of $\mathrm{O}_{3}$. Figure 3 provides an illustration of the global distribution in surface $\mathrm{NO}_{2}$ during May 2006 for both the $3^{\circ} \times 2^{\circ}$ and $1^{\circ} \times 1^{\circ}$ simulations, where the short lifetime means that the maximum mixing ratios occur directly near the strong source regions. Most $\mathrm{NO}_{x}$ is anthropogenic in origin; therefore, there is a strong latitudinal gradient between the $\mathrm{NH}$ and $\mathrm{SH}$, with ship tracks also visible. The regions where validation occurs are also superimposed 
Table 5. The annual NO to $\mathrm{NO}_{2}$ recycling terms involving peroxy radicals given in $\mathrm{Tg} \mathrm{N} \mathrm{yr}{ }^{-1}$ for 2006 at $1^{\circ} \times 1^{\circ}$ resolution. In mCB05v2 $\mathrm{XO}_{2}$ represents lumped alkyl-peroxy radicals (Yarwood et al., 2005). The $\mathrm{NO}+\mathrm{RO}_{2}$ term is an aggregate of numerous specific peroxyradical conversion terms in the modified CB05 mechanism (Williams et al., 2013; Tables 1 and 2). Also provided are the approximate percentage differences when comparing with $3^{\circ} \times 2^{\circ}$ (equal to $\left.\left(1^{\circ} \times 1^{\circ}\right)-\left(3^{\circ} \times 2^{\circ}\right) / 3^{\circ} \times 2^{\circ}\right)$. The chemical tropopause is defined using the methodology outlined in Stevenson et al. (2006).

\begin{tabular}{lrrrrrrrr}
\hline Reaction & Global & $\%$ & $\mathrm{SH}$ & $\%$ & Tropics & $\%$ & $\mathrm{NH}$ & $\%$ \\
\hline $\mathrm{NO}+\mathrm{HO}_{2}$ & 1058 & -1.2 & 79 & -1.2 & 740 & -1.9 & 239 & 0.8 \\
$\mathrm{NO}+\mathrm{CH}_{3} \mathrm{O}_{2}$ & 407 & -2.2 & 31 & -2.6 & 294 & -2.8 & 82 & -2.0 \\
$\mathrm{NO}+\mathrm{XO}_{2}$ & 147 & -2.1 & 7 & -3.6 & 111 & -2.6 & 29 & - \\
$\mathrm{NO}+\mathrm{RO}_{2}$ & 9.4 & -4.4 & 0.4 & -2.6 & 6.3 & -4.4 & 2.7 & -4.2 \\
\hline $\mathrm{NO}+\mathrm{O}_{3}$ & 5403 & 0.1 & 518 & 7.5 & 2933 & -3.9 & 1953 & 4.9 \\
\hline
\end{tabular}

in the figure, including the extent of the EMEP domain over which $\mathrm{NO}_{2}$ weekly comparisons are made.

Figures 5 and 6 show comparisons of weekly [NO] and $\left[\mathrm{NO}_{2}\right]$ surface measurements with the corresponding composites from both simulations, sampled at 13:00 local time, which is close to the local overpass time for both OMI and tropOMI. Although the number of EMEP sites conducting $\mathrm{NO}_{x}$ measurements is smaller than those measuring $\mathrm{O}_{3}$, we choose stations located throughout Europe in both high- and low- $\mathrm{NO}_{x}$ regimes. To supplement these comparisons we provide the seasonal mean biases for DJF and JJA from both simulations in Tables 6 and 7, respectively, calculated using weekly binned data from all EMEP sites that measure hourly [NO] and $\left[\mathrm{NO}_{2}\right]$. Here we perform an analysis across sites rather than focusing on the behaviour at selected individual locations.

For the determination of $\left[\mathrm{NO}_{2}\right]$, the reduction of $\mathrm{NO}$ on a Molybdenum convertor takes place with subsequent detection by chemi-luminescence, with an associated detection limit of $\sim 0.4 \mathrm{ppb}$. Previous studies have shown that some bias can result due to the oxidation of nitrogen reservoirs such as PAN (Dunlea et al., 2007; Steinbacher et al., 2007). In TM5-MP all $\mathrm{NO}_{x}$ emissions are introduced as $\mathrm{NO}$, although a fraction for road transport is known to be emitted directly as $\mathrm{NO}_{2}$ (e.g. Carslaw and Beevers, 2005). Many studies have been performed comparing satellite $\mathrm{NO}_{2}$ columns with model values, implying that inadequacies in emission inventories are somewhat region-specific (e.g. Zyrichidou et al., 2015; Pope et al., 2015).

Table 6 shows a negative bias of a few $\mu \mathrm{g} \mathrm{m}^{-3}$ in TM5MP in seasonal surface [NO] in Europe. This is a cumulative effect of the accuracy of the MACC $\mathrm{NO}_{x}$ emission estimates, an overestimate in daytime vertical mixing (Koffi et al., 2016) (enhanced dilution) and, to a lesser extent, overly high surface $\left[\mathrm{O}_{3}\right]$ (increasing the oxidation rate of $\mathrm{NO}$ to $\mathrm{NO}_{2}$ ). As anthropogenic emissions are the principle source of NO, there is no significant seasonal cycle in the monthly emission estimates in the NH. Seasonal differences in convective mixing (i.e. lower BL heights) do cause somewhat higher surface [NO] during DJF for approximately equal emission terms. This is captured by TM5-MP, although under night-time conditions TM5-MP has been shown to overestimate nocturnal BL heights (Koffi et al., 2016). For $\sim 80 \%$ of the EMEP sites we do not observe any significant change in the quality of the comparisons. For $\sim 20 \%$ of sites, simulations of $[\mathrm{NO}]$ at $1^{\circ} \times 1^{\circ}$ introduce significant improvements over those at $3^{\circ} \times 2^{\circ}$, and there is an improvement regarding the extent of seasonal variability (Fig. 4).

Table 7 shows that for $\left[\mathrm{NO}_{2}\right]$ the biases are more variable, being typically in the range of $\pm 0-6 \mu \mathrm{g} \mathrm{m}^{-3}$, with both positive and negative biases occurring across sites. The conversion efficiency from $\mathrm{NO}$, loss to reservoir compounds (e.g. $\mathrm{HNO}_{3}$ ), photo-dissociation rate, convective mixing and emission estimates all contribute to these biases. The seasonal biases show improvements at $1^{\circ} \times 1^{\circ}$ for $\sim 35 \%$ of the EMEP sites, accompanied by degradations at $\sim 20 \%$ of the sites. The maximum biases in $\left[\mathrm{NO}_{2}\right]$ at $1^{\circ} \times 1^{\circ}$ can be approximately double those for [NO]. For the corresponding $\mathrm{NO} / \mathrm{NO}_{2}$ ratio, there will generally be an underprediction in the model due to the negative biases shown for the [NO] comparisons. Analysing the corresponding seasonal correlation coefficients (not shown) shows that in $\sim 25 \%$ of the cases there is little seasonal correlation between the weekly $\left[\mathrm{NO}_{2}\right]$ in TM5-MP and the measurements regardless of resolution for both seasons (Pearson's $r$ in the range -0.3 to 0.3 ). In $\sim 30 \%$ of cases there is actually a degradation in $r$ between resolutions, the changes somewhat reflect those seen in the seasonal biases, i.e. simultaneous changes to both the meteorology and local emission fluxes do not necessarily improve the performance of the model. Comparing $1^{\circ} \times 1^{\circ}$ values both with and without the Tiedtke convection scheme shows that for the most convective regions (e.g. south of $45^{\circ} \mathrm{N}$ ) increases in $r$ generally occur during JJA when employing the ERA-Interim mass fluxes. Conversely for e.g. Finland the correlation becomes worse.

Beyond Europe, we compared monthly mean TM5-MP vertical distributions of $\mathrm{NO}$ and $\mathrm{NO}_{2}$ between March and May 2006 against measurements taken during the INTEXB campaign in Fig. 7. In general differences between $1^{\circ} \times 1^{\circ}$ and $3^{\circ} \times 2^{\circ}$ simulations are of the order of a few percent, 

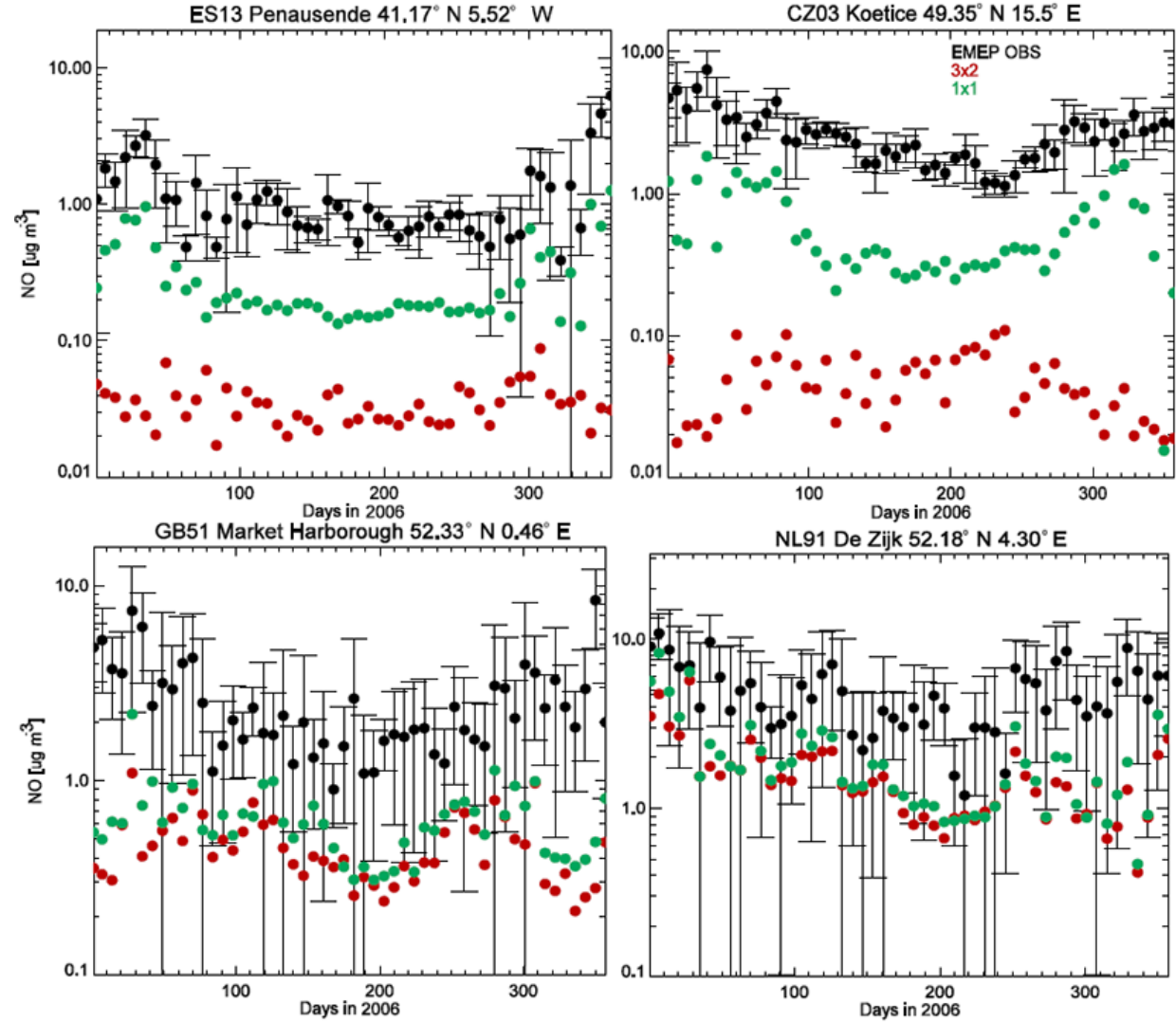

Figure 5. Comparison of TM5-MP weekly [NO] sampled at 13:00 UT each day during 2006 with observed [NO] $\left(\mu \mathrm{g} \mathrm{m}^{-3}\right)$. The selected sites shown are in the Czech Republic (top left), Spain (top right), Great Britain (bottom left) and the Netherlands (bottom right).
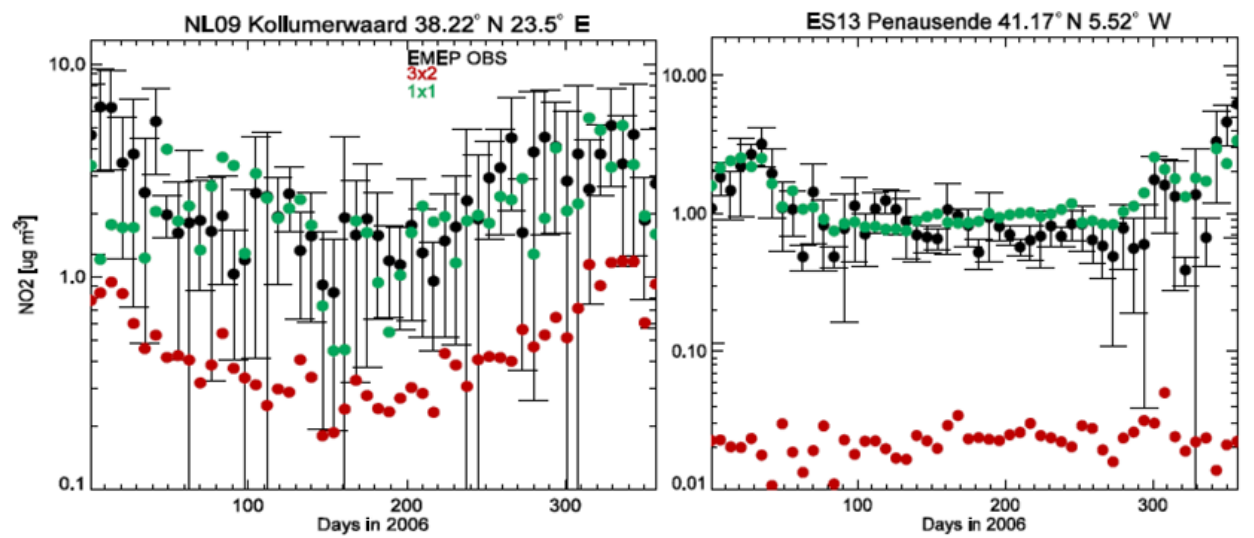

Figure 6. Comparison of weekly TM5-MP $\left[\mathrm{NO}_{2}\right]$ sampled at 13:00 UT each day during 2006 with observed $\left[\mathrm{NO}_{2}\right]\left(\mu \mathrm{g} \mathrm{m}^{-3}\right)$. The selected sites shown are in the Netherlands (left) and Spain (right).

with $\mathrm{NO}_{2}$ biased low in the LT by $\sim 70-80 \%$. This is partially associated with the take-off and landing of the aircraft from polluted airfields, where point sources of high anthropogenic emissions cannot be resolved even at $1^{\circ} \times 1^{\circ}$. For March, there is a strong signature from biomass burning plumes in the middle troposphere which is not captured using the monthly burning estimates. For the FT, TM5-MP captures the observed gradient to a reasonable degree. In the UT there is a consistent high bias for $\mathrm{NO}$ and an associated low bias for $\mathrm{NO}_{2}$, suggesting that the conversion term is too low and that the $\mathrm{NO}_{x}$ cycle is out of synch at these cold temperatures despite the addition of new reservoir species (i.e. $\mathrm{CH}_{3} \mathrm{O}_{2} \mathrm{NO}_{2}$ ) and application of new rate data. 
Table 6. The seasonal mean absolute biases as calculated using weekly [NO] values $\left(\mu \mathrm{g} \mathrm{m}^{-3}\right)$. The weekly means are composed from daily measurements taken at 13:00 for DJF and JJA (given as the difference in the measurements-model). Values are shown for both the $3^{\circ} \times 2^{\circ}$ and $1^{\circ} \times 1^{\circ}$ simulations for all stations with available data. Those with differences $<5 \%$ are considered to exhibit no discernible change in the bias.

\begin{tabular}{lrrrrrr}
\hline EMEP station & Lat & Lon & DJF $3^{\circ} \times 2^{\circ}$ & DJF $1^{\circ} \times 1^{\circ}$ & JJA $3^{\circ} \times 2^{\circ}$ & JJA $1^{\circ} \times 1^{\circ}$ \\
\hline CH01 & 46.32 & 7.59 & -0.01 & -0.01 & 0.00 & -0.01 \\
CZ03 & 49.35 & 15.50 & -4.05 & -3.30 & -1.61 & -1.35 \\
DE43 & 47.48 & 11.10 & -2.37 & -2.36 & -0.47 & -0.48 \\
DK05 & 54.44 & 10.44 & -2.51 & -2.61 & -1.29 & -1.51 \\
ES07 & 58.23 & 21.49 & -3.80 & -3.84 & -1.45 & -1.48 \\
ES08 & 43.26 & -4.51 & -2.08 & -2.09 & -1.00 & -1.01 \\
ES09 & 41.16 & -3.80 & -0.93 & -0.93 & -1.07 & -1.07 \\
ES10 & 38.28 & 3.19 & -1.14 & -1.24 & -0.75 & -0.88 \\
ES11 & 39.50 & -6.55 & -1.07 & -1.07 & -0.44 & -0.45 \\
ES12 & 41.17 & -1.60 & -1.34 & -1.34 & -0.95 & -0.95 \\
ES13 & 41.24 & -5.52 & -2.50 & -1.90 & -0.74 & -0.62 \\
ES14 & 39.31 & 0.43 & -2.21 & -2.20 & -1.27 & -1.27 \\
ES15 & 43.13 & -4.21 & -1.62 & -1.61 & -0.99 & -1.00 \\
ES16 & 43.37 & -7.41 & -2.39 & -2.39 & -1.11 & -1.11 \\
FR13 & 46.39 & 0.11 & -1.90 & -1.94 & -0.52 & -0.52 \\
FR15 & 55.18 & 0.45 & -3.09 & -3.04 & -1.51 & -1.58 \\
GB02 & 50.35 & -3.12 & -1.23 & -1.23 & -0.93 & -0.92 \\
GB13 & 54.20 & -3.42 & -1.28 & -1.32 & -0.58 & -0.55 \\
GB14 & 52.30 & -0.48 & -3.03 & -3.04 & -0.98 & -0.98 \\
GB31 & 53.23 & -3.11 & -1.74 & -1.74 & -0.90 & -0.91 \\
GB37 & 50.47 & -1.45 & -3.09 & -3.08 & -1.22 & -1.21 \\
GB38 & 51.13 & 0.10 & -2.87 & -2.78 & -1.92 & -1.72 \\
GB44 & 51.17 & -3.20 & -1.65 & -1.45 & -0.27 & -0.67 \\
GB45 & 52.17 & 0.17 & -1.80 & 0.11 & 0.20 & 0.19 \\
GB51 & 52.33 & 0.46 & -3.68 & -3.42 & -1.29 & -1.17 \\
NL91 & 52.18 & 4.30 & -4.47 & -3.51 & -1.98 & -1.86 \\
\hline & & & & & &
\end{tabular}

One important gauge as to whether the chemical mechanism can capture the correct recycling efficiency of NO into $\mathrm{NO}_{2}$ is to examine their ratio, which is presented in the third column of Fig. 7. In the LT $(<900 \mathrm{hPa}) \mathrm{NO} / \mathrm{NO}_{2}$ ratios of $0.1-0.2$ exist that are captured quite well by TM5-MP, with negligible differences between $3^{\circ} \times 2^{\circ}$ and $1^{\circ} \times 1^{\circ}$ simulations. For the FT, TM5-MP consistently overestimates the ratio in spite of a high bias in $\mathrm{O}_{3}$ (cf. Fig. 4) which is imposed by the overestimates in $\mathrm{NO}_{2}$. This implies the chemical conversion is too slow and, assuming representative $J_{\mathrm{NO}_{2}}$ values, indicates a low bias in $\mathrm{HO}_{2}$ or an underestimation in the mixing ratios of other long-lived and short-lived $\mathrm{NO}_{y}$ compounds (see Sect. 7).

Finally in Fig. 8 we show the corresponding comparisons against measurements taken during the TexAQS II campaign (Parrish et al., 2009) for both September and October 2006. As for the EMEP comparisons shown in Figs. 5 and 6, there is a significant underestimation in $\mathrm{NO}$ and $\mathrm{NO}_{2}$ mixing ratios, with both model profiles being outside the $1 \sigma$ variability in the observational mean. This is clearly related to the emission estimates for this region being underestimated in the current emission inventories (e.g. Kim et al., 2011). For the resulting $\mathrm{NO} / \mathrm{NO}_{2}$ ratio, TM5-MP captures the correct ratio in the lowest few hundred metres of the BL, but overestimates the ratio at higher altitudes as for more pristine environments, although there is marked improvement in the ratios simulated for October.

\section{Changes in the $\mathrm{NO}_{y}$ budget}

\subsection{Long-lived reservoirs}

The resolution-dependent changes in the temporal distribution of $\left[\mathrm{NO}_{2}\right]$ and associated differences in NMVOC chemical precursor emissions have the potential to alter the partitioning of reactive $\mathrm{NO}_{x}$ between the three main chemical reservoirs included in $\mathrm{mCB} 05 \mathrm{v} 2$ (i.e. $\mathrm{HNO}_{3}, \mathrm{PAN}$ and ORGNTR). The differences in both the deposition efficiency and tropospheric lifetimes between trace species at $1^{\circ} \times 1^{\circ}$ suggests that the fraction of $\mathrm{NO}_{x}$ that can be transported out of source regions could change significantly. Here we briefly examine the zonally integrated nitrogen budget terms between simulations to quantify the effect of applying a higher spatial resolution. The seasonal distribution of these three 
Table 7. As for Table 5 except for $\mathrm{NO}_{2}$.

\begin{tabular}{|c|c|c|c|c|c|c|}
\hline EMEP station & Lat & Lon & DJF $3^{\circ} \times 2^{\circ}$ & $\mathrm{DJF} 1^{\circ} \times 1^{\circ}$ & $\mathrm{JJA} 3^{\circ} \times 2^{\circ}$ & JJA $1^{\circ} \times 1^{\circ}$ \\
\hline BE32 & 50.30 & 4.59 & 10.56 & 1.27 & 1.69 & -2.13 \\
\hline $\mathrm{CH} 01$ & 46.32 & 7.59 & -0.04 & -0.03 & -0.02 & -0.01 \\
\hline CZ03 & 49.35 & 15.50 & -4.04 & 0.03 & -1.62 & 0.34 \\
\hline DE43 & 47.48 & 11.10 & -2.37 & -2.36 & -0.49 & -0.48 \\
\hline DK05 & 54.44 & 10.44 & 6.07 & 5.56 & 1.04 & -0.02 \\
\hline ES07 & 58.23 & 21.49 & -1.13 & -1.79 & -0.96 & -1.15 \\
\hline ES08 & 43.26 & -4.51 & -2.01 & -2.10 & -0.93 & -1.01 \\
\hline ES09 & 41.16 & -3.80 & -0.95 & -0.94 & -1.07 & -1.07 \\
\hline ES10 & 42.19 & 3.19 & 2.18 & 1.46 & 0.92 & -0.01 \\
\hline ES11 & 38.28 & -6.55 & -1.08 & -1.08 & -0.44 & -0.44 \\
\hline ES12 & 39.50 & -1.60 & -1.36 & -1.35 & -0.95 & -0.95 \\
\hline ES13 & 41.17 & -5.52 & -2.51 & -0.29 & -0.74 & 0.19 \\
\hline ES14 & 41.24 & 0.43 & -2.22 & -2.21 & -1.27 & -1.26 \\
\hline ES15 & 39.31 & -4.21 & -1.64 & -1.63 & -0.99 & -0.99 \\
\hline ES16 & 43.13 & -7.41 & -2.40 & -2.39 & -1.11 & -1.11 \\
\hline FI09 & 59.46 & 21.22 & 0.79 & -0.91 & -0.10 & -0.53 \\
\hline FI37 & 60.31 & 27.41 & 10.04 & 9.60 & 1.70 & 0.92 \\
\hline FI96 & 62.35 & 24.11 & 0.40 & 0.34 & 0.31 & 0.17 \\
\hline FR13 & 43.37 & 0.11 & -1.96 & -1.95 & -0.54 & -0.54 \\
\hline FR15 & 46.39 & 0.45 & -3.84 & -3.91 & -1.78 & -1.81 \\
\hline GB02 & 55.18 & -3.12 & 3.12 & 3.42 & 0.82 & 0.54 \\
\hline GB13 & 50.35 & -3.42 & -2.17 & -2.13 & -1.00 & -0.98 \\
\hline GB14 & 54.20 & -0.48 & 5.02 & 3.93 & 1.17 & 1.50 \\
\hline GB31 & 52.30 & -3.11 & -1.71 & -1.71 & -0.90 & -0.90 \\
\hline GB37 & 53.23 & -1.45 & -3.10 & -3.08 & -1.25 & -1.25 \\
\hline GB38 & 50.47 & 0.10 & -4.05 & -4.03 & -2.20 & -2.19 \\
\hline GB44 & 51.13 & -3.20 & 6.21 & 6.69 & 0.61 & 1.42 \\
\hline GB45 & 52.17 & -0.17 & 6.28 & 6.00 & 3.48 & 1.94 \\
\hline GB51 & 52.33 & -0.46 & 12.56 & 16.60 & 4.11 & 4.50 \\
\hline GR01 & 41.45 & 42.49 & 0.50 & 2.07 & 0.40 & 1.05 \\
\hline NL09 & 53.2 & 6.16 & -3.21 & -1.63 & -1.18 & -0.19 \\
\hline NL10 & 51.32 & 5.51 & 3.48 & 3.52 & 0.92 & -0.29 \\
\hline NL91 & 52.18 & 4.30 & 11.81 & 6.42 & 1.48 & -0.81 \\
\hline
\end{tabular}

dominant reservoir species at $1^{\circ} \times 1^{\circ}$ and their individual contributions to total $\mathrm{NO}_{y}$ are shown in Figs. S12-S15 for DJF and JJA, respectively. Here we define $\mathrm{NO}_{y}$ as the cumulative total of $\mathrm{NO}, \mathrm{NO}_{2}, \mathrm{NO}_{3}, \mathrm{HNO}_{3}, \mathrm{PAN}, \mathrm{CH}_{3} \mathrm{O}_{2} \mathrm{NO}_{2}$, HONO, $2 \cdot \mathrm{N}_{2} \mathrm{O}_{5}$, lumped organic nitrates (ORGNTR) and $\mathrm{HNO}_{4}$. It should be noted that methyl-nitrate is not in this version of TM5-MP. These figures are provided as a reference for the reader to aid understanding of the discussion below.

Table S1 in the Supplement provides a zonal decomposition of the tropospheric chemical budget terms for $\mathrm{HNO}_{3}$, PAN and ORGNTR. For $\mathrm{HNO}_{3}$, even though the recent kinetic rate parameters increase (decrease) the chemical production term at the surface (UTLS) compared to older rate data (e.g. Seltzer et al., 2015), changes in the integrated column term are small. The changes at $1^{\circ} \times 1^{\circ}$ are somewhat latitude-dependent (corresponding to low- and high$\mathrm{NO}_{x}$ regimes), with only small increases occurring in the $\mathrm{NH}$ and associated decreases in the tropics related to lower
[OH] (i.e. chemical production). Loss by cumulative deposition terms only changes by a few percent, due to wet scavenging being so efficient for $\mathrm{HNO}_{3}$ for any associated change in the SAD of cloud droplets $\left(\mathrm{cm}^{2} / \mathrm{cm}^{3}\right)$ introduced by changes in the liquid water product.

For PAN, both the production and destruction terms decrease marginally by $\sim 1-3 \%$ across all zones, meaning the transport of $\mathrm{NO}_{x}$ out of the main source regions remains relatively robust. The total mass of $\mathrm{N}$ cycled through PAN is $\sim 4$ times that sequestrated as $\mathrm{HNO}_{3}$, although the lifetime of PAN is shorter due to the efficient thermal decomposition. The changes in the production term due to temporal increases in $\mathrm{NO}_{2}$ near high- $\mathrm{NO}_{x}$ source regions (cf. Fig. 3) are partially offset by a reduction in the mixing ratios of the acetyl-peroxy radical $\left(\mathrm{C}_{2} \mathrm{O}_{3}\right.$ in Table 1$)$ due to e.g. increased dry deposition of organic precursors at $1^{\circ} \times 1^{\circ}$. Although the chemical budget terms only exhibit small changes, it can be expected that the global distribution of PAN will be somewhat different due to the changes in the convective and advective mixing due to 

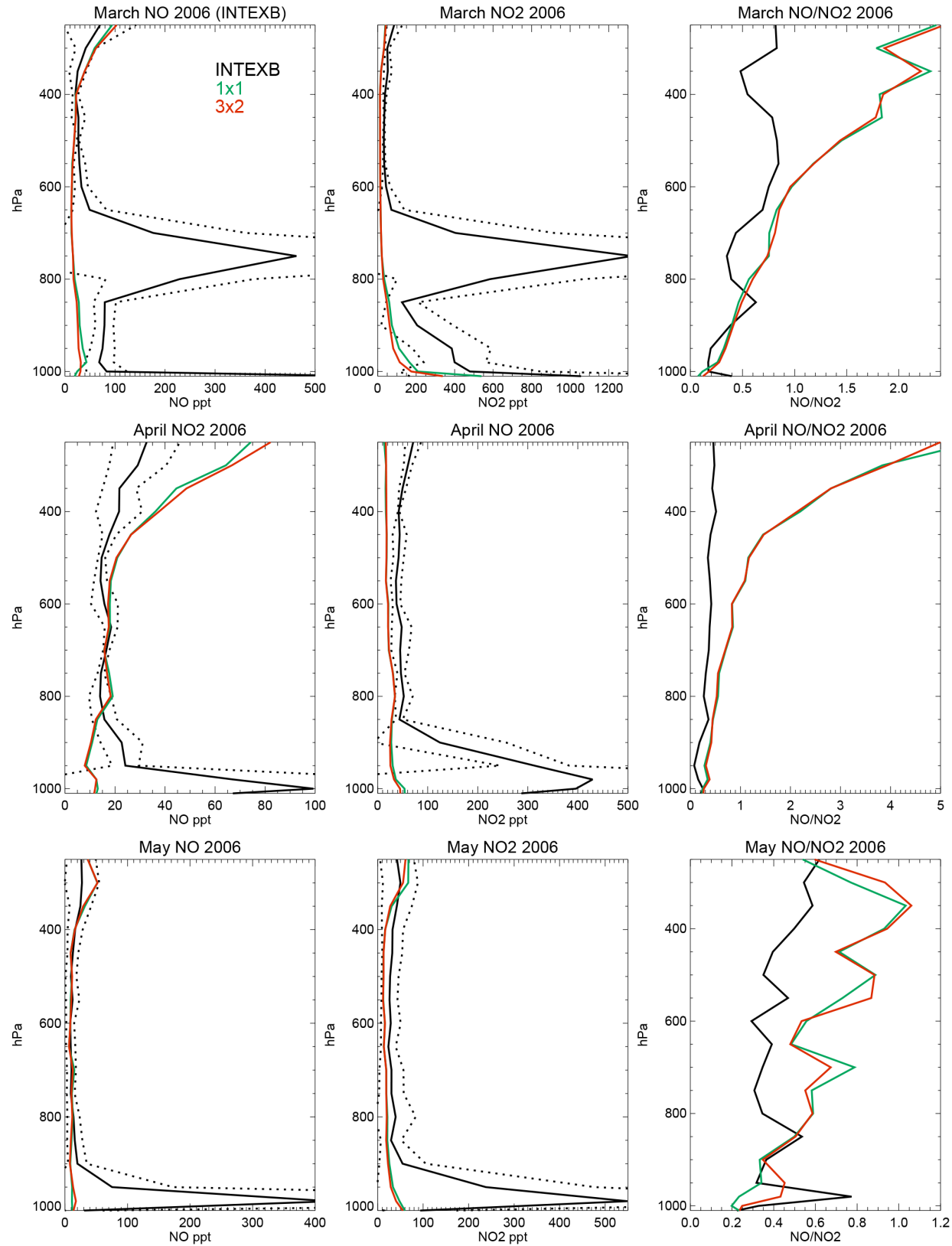

Figure 7. Monthly mean comparisons of $\mathrm{NO}$ (left), $\mathrm{NO}_{2}$ (middle) and the resulting $\mathrm{NO} / \mathrm{NO}_{2}$ ratio (right) from INTEX-B measurements and TM5-MP simulations. The dotted line represents the $1 \sigma$ deviation in the mean of the measurements. For details of the locations for each month the reader is referred to Singh et al. (2009).

the application of higher-resolution meteorological data (cf. Sect. 3).

For ORGNTR, there is a $5 \%$ reduction in the annual production term at $1^{\circ} \times 1^{\circ}$, with an associated decrease in the loss by deposition. Both the largest production and, thus, destruction terms occur in the tropics related to the strongest source of ORGNTR being biogenic precursors in mCB05v2. Thus, at $1^{\circ} \times 1^{\circ}$, this intermediate trace species becomes less important as a $\mathrm{NO}_{x}$ reservoir.
Finally, the one additional intermediate not shown is $\mathrm{CH}_{3} \mathrm{O}_{2} \mathrm{NO}_{2}$, which is primarily a stable vehicle for transporting $\mathrm{NO}_{x}$ from the surface up to the UTLS, where at cold temperatures it accounts for a significant fraction of $\mathrm{NO}_{2}$ speciation along with $\mathrm{HNO}_{4}$ (Browne et al., 2011). At the global scale 3 times as much nitrogen cycles through $\mathrm{CH}_{3} \mathrm{O}_{2} \mathrm{NO}_{2}$ compared to PAN, although the thermal stability is low at temperatures $>255 \mathrm{~K}$; thus, resident mixing ratios are typically small. This results in maximum mixing ratios occurring in the cold upper troposphere (up to $\sim 0.2 \mathrm{ppb}$ ) and sub- 

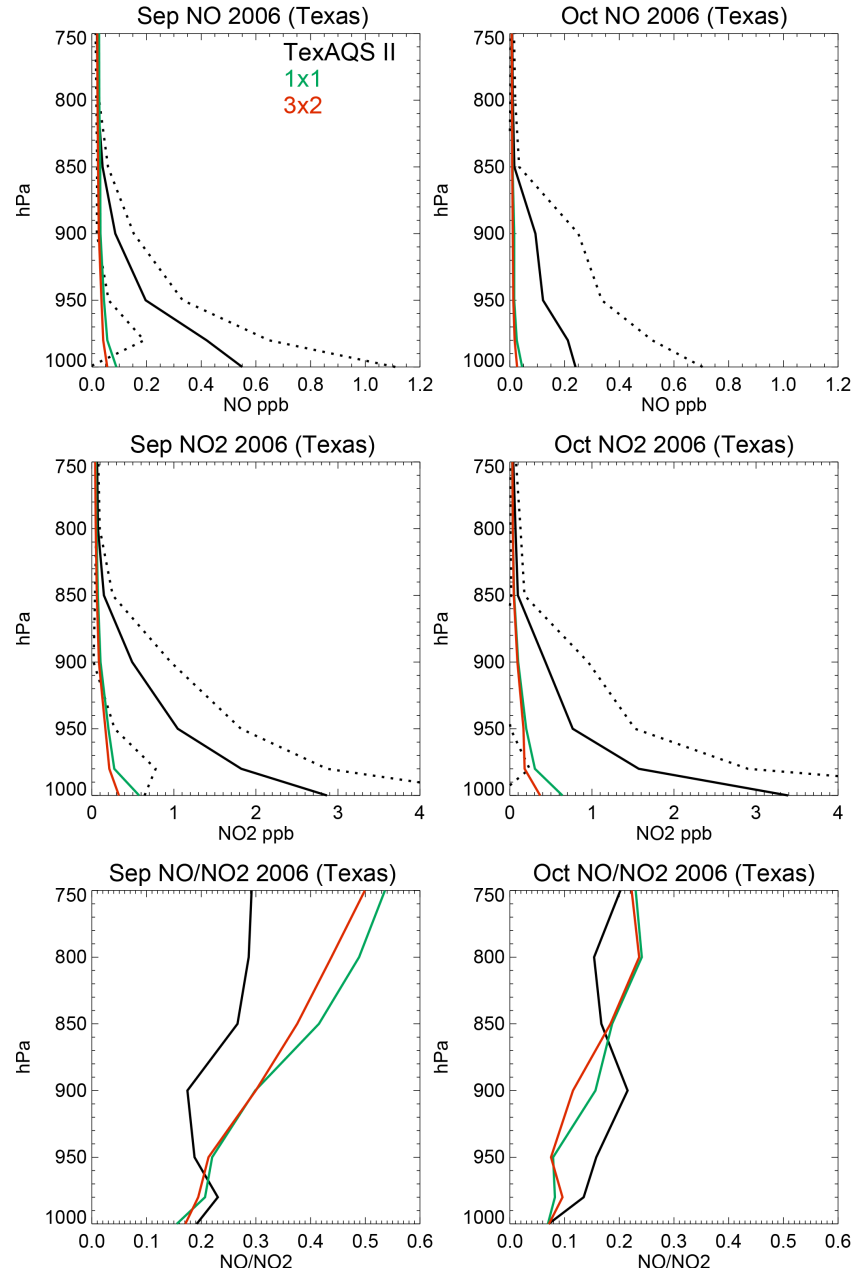

Figure 8. Monthly mean comparisons of $\mathrm{NO}$ (left), $\mathrm{NO}_{2}$ (middle) and the resulting $\mathrm{NO} / \mathrm{NO}_{2}$ ratio (right) from the TexAQSII campaign during September and October 2006 and TM5-MP simulations. The dotted line represents the $1 \sigma$ deviation in the mean of the measurements. For details of the locations for each month the reader is referred to Parrish et al. (2009).

sequently dissociating primarily by thermal decomposition (photolytic destruction accounting for $>0.1 \%$ of all destruction). At $1^{\circ} \times 1^{\circ}$ there is a few percent decrease in the chemical production term as a result of lower $\mathrm{CH}_{3} \mathrm{O}_{2}$ mixing ratios and more variability in the temporal temperature distribution.

Comparisons of weekly $\left[\mathrm{HNO}_{3}\right]$ at the surface in Europe are shown in Fig. 9 against measurements from the EMEP network. It has recently been determined that $\mathrm{HNO}_{3}$ measurements are also sensitive to ambient night-time $\left[\mathrm{N}_{2} \mathrm{O}_{5}\right]$, which could result in a positive bias in the observations (Phillips et al., 2013). In general, the modelled seasonal cycle is not evident in the measurements, which exhibit a rather homogeneous variation in mixing ratios throughout the year typically, thus being somewhat decoupled from variability in photochemical activity. Comparisons show an underestimation in TM5-MP during March and an overestimation during JJA. No such seasonal pattern is observed for $\left[\mathrm{NO}_{2}\right]$ (cf. Fig. 6); thus, seasonal $[\mathrm{OH}]$ variability due to variations in photo-chemical activity and $\left[\mathrm{H}_{2} \mathrm{O}_{(\mathrm{g})}\right]$ and/or an incorrect wash-out term could both act as likely causes. The impact of resolution on $\left[\mathrm{HNO}_{3}\right]$ is rather muted for most weeks, resulting in no significant changes to the seasonal biases (not given), as constrained by the improvements in surface $\left[\mathrm{NO}_{2}\right]$ (cf. Fig. 6). The heterogeneous scavenging of $\mathrm{HNO}_{3}$ into ammonium nitrate can act as a moderator of gaseous $\mathrm{HNO}_{3}$. Although this heterogeneous conversion process is included in TM5-MP as described by the EQSAM approach, low concentrations of e.g. ammonium nitrate (not shown) typically result. Thus, gaseous $\left[\mathrm{HNO}_{3}\right]$ remains too high due to too little conversion into particles and subsequent deposition.

For other regions outside Europe, we make comparisons of vertical profiles of $\mathrm{HNO}_{3}$ and PAN between March and September 2006 with those measured during INTEX-B (Fig. 10) and TexAQSII (Fig. S16). PAN is a good marker for transport in the free troposphere due to the relatively long lifetime at colder temperatures. For all regions the vertical gradients for both species are captured quite well, although some fine structure is lost due to the vertical resolution of TM5-MP and insufficient precursor emissions. This implies that the underestimation in $\mathrm{NO}_{2}$ simulated in the UTLS (Fig. 7) is not due to insufficient transport of $\mathrm{NO}_{2}$ away from source regions, but rather should be attributed to either missing chemistry or insufficient transport down from the stratosphere. Finally, for more polluted regions, the vertical gradient of $\mathrm{HNO}_{3}$ is rather less steep than that observed, with significant low biases in the lower troposphere related to the low bias in $\mathrm{NO}_{2}$ shown in Fig. 8. The impact of the $1^{\circ} \times 1^{\circ}$ resolution only results in a marginal improvement in the LT for $\mathrm{HNO}_{3}$ (again similar to $\mathrm{NO}_{2}$ ). For PAN the vertical profile in TM5-MP agrees remarkably well, but is somewhat anti-correlated around $900 \mathrm{hPa}$ in both simulations, and the rapid decrease in the lowest kilometre is captured sufficiently. This overestimation would likely be larger if the emission estimates were increased as required to consolidate the $\mathrm{NO}_{2}$ comparisons for the same campaign.

\subsection{Short-lived reservoirs}

Here we briefly discuss the perturbations introduced for the short-lived $\mathrm{N}$-reservoirs, namely $\mathrm{HONO}, \mathrm{HNO}_{4}$ and $\mathrm{N}_{2} \mathrm{O}_{5}$, where the chemical budget terms for all three species are provided in Table S2 in the Supplement. For HONO it should be noted that many tropospheric CTMs have difficulty in simulating observed mixing ratios (e.g. Gonçalves et al., 2012), suggesting missing (heterogeneous) source terms. The global production for HONO is an order of magnitude less than that for the other short-lived N-reservoirs. At $1^{\circ} \times 1^{\circ}$ there is $\sim 10 \%$ more chemical production of $\mathrm{HONO}$ in high- $\mathrm{NO}_{x}$ regions and no appreciable effect in low- $\mathrm{NO}_{x}$ regions. Thus the impact of increased resolution on $\mathrm{HONO}$ production is rather small, which is surprising considering the higher NO mixing 

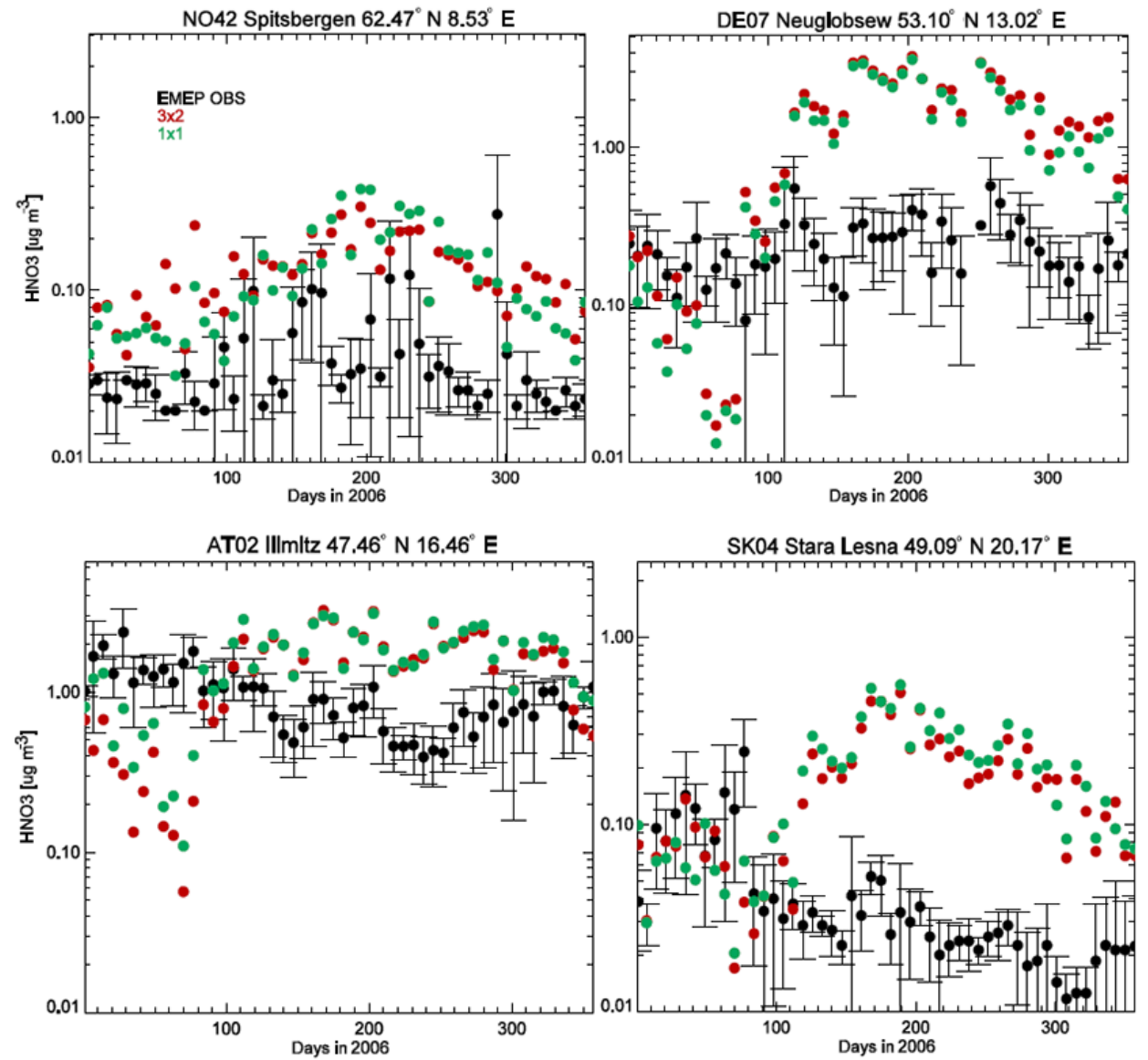

Figure 9. Comparison of weekly $\left[\mathrm{HNO}_{3}\right]\left(\mu \mathrm{g} \mathrm{m}{ }^{-3}\right)$ from both $3^{\circ} \times 2^{\circ}$ and $1^{\circ} \times 1^{\circ}$ simulations at 4 selected EMEP sites for 2006 . The $1 \sigma$ deviation in the weekly observations are shown as error bars. The selected sites shown are in Norway (top left), Germany (top right), Austria (bottom left) and Slovakia (bottom right).

ratios that occur in high-NO $\mathrm{N}_{x}$ regions (cf. Fig. 5). The muted response is due to competing oxidative processes, which effectively lower the $\mathrm{OH}$ available. For $\mathrm{HNO}_{4}$, approximately the same mass of $\mathrm{N}$ cycles through this species as for PAN, although the shorter lifetime means that it is more important at regional scale. Again, the impact of resolution on this species is small, where decreases in $\left[\mathrm{HO}_{2}\right]$ result in no significant net change in production for the NH. The most significant changes occur for the global production and heterogeneous conversion of $\mathrm{N}_{2} \mathrm{O}_{5}$, with enhanced chemical production of $\sim 12 \%$ at the global scale, increasing the heterogeneous sink term by $\sim 6 \%$, although the changes in the total mass of $\mathrm{N}$ converted are small. In general, this is due to an increase in the production of the $\mathrm{NO}_{3}$ radical by $\sim 10 \%$ at $1^{\circ} \times 1^{\circ}$ (not shown) resulting in enhanced $\mathrm{N}_{2} \mathrm{O}_{5}$ mixing ratios.

\section{Implications for tropospheric $\mathrm{CH}_{2} \mathrm{O}$ retrieval}

The implications of applying a higher-resolution CTM for the global distribution of $\mathrm{CH}_{2} \mathrm{O}$ are rather modest. Fig- ure $\mathrm{S} 17$ shows the near-surface global distributions of $\mathrm{CH}_{2} \mathrm{O}$ for May 2006, where maximum mixing ratios occur near forested regions due to the link with isoprene oxidation (e.g. Palmer et al., 2006). The tropospheric lifetime of $\mathrm{CH}_{2} \mathrm{O}$ is of the order of a few days, meaning that transport has little impact between simulations, apart from in low-emission areas. Also shown are the locations where regional validation occurs. In Table 8, we show zonally integrated chemical production and destruction terms for $\mathrm{CH}_{2} \mathrm{O}$, which suggests changes of the order of a few percent at the global scale. The most notable difference is the increase in the cumulative deposition term of $\sim 4 \%$ at $1^{\circ} \times 1^{\circ}$, thus reducing the atmospheric lifetime of $\mathrm{CH}_{2} \mathrm{O}$ in TM5-MP. Again, this low impact shows that the increase in the temporal variability of the meteorological data at $1^{\circ} \times 1^{\circ}$, and thus the local variability of cloud SAD, only changes the net deposition term by a few percent. Even though the temporal distribution of the surface mixing ratios shows more variability at $1^{\circ} \times 1^{\circ}$ due to the better representation of regional precursor source terms (e.g.) isoprene and terpene, only moderate improvements occur to the simulated profiles and total columns due to changes 

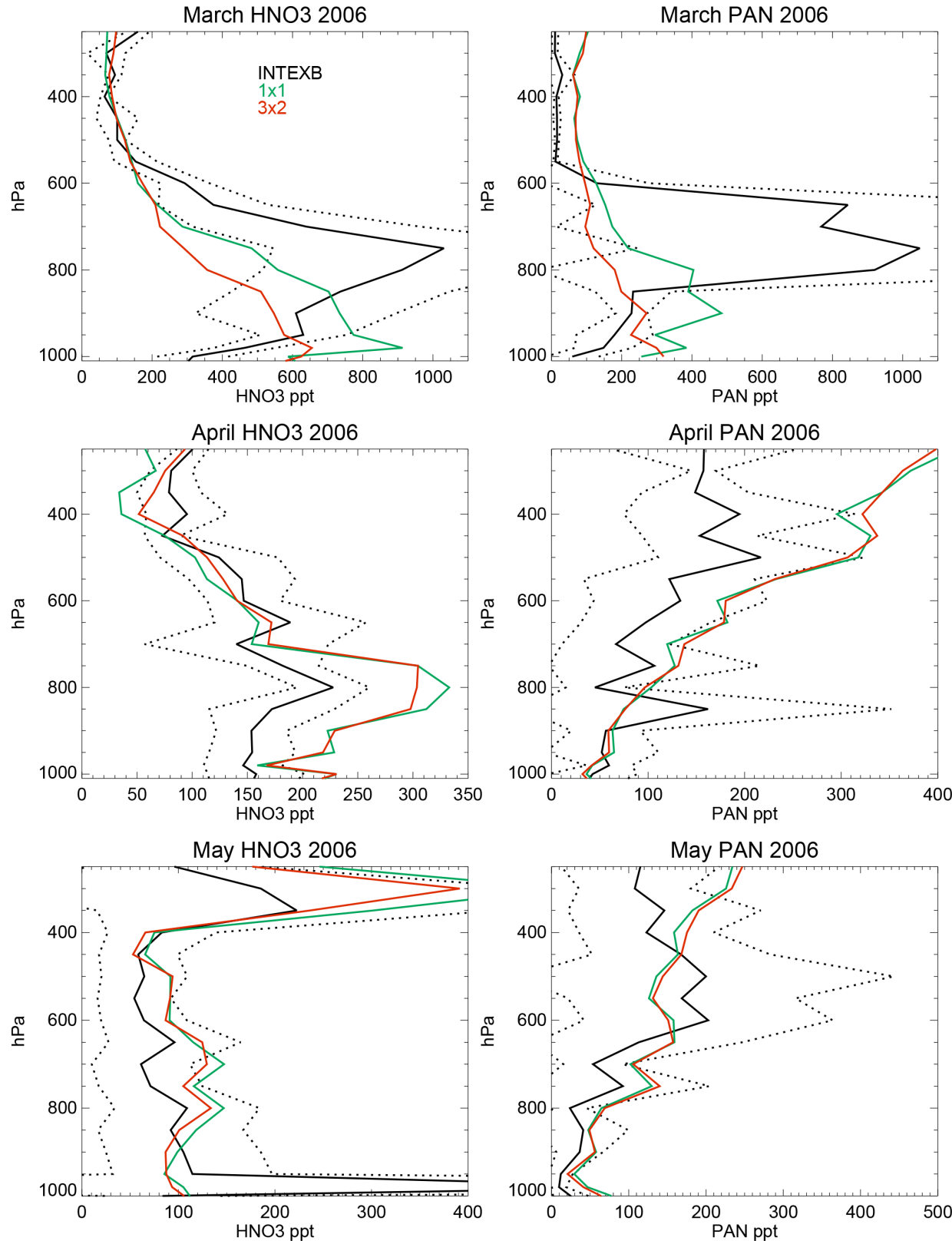

Figure 10. Monthly mean comparisons of $\mathrm{HNO}_{3}$ (left) and PAN (right) from the INTEX-B measurements and TM5-MP simulations. The dotted line represents the $1 \sigma$ deviation in the mean of the measurements. For details of the locations for each month the reader is referred to Singh et al. (2009).

in transport. For instance, when analysing individual production terms (not given) for the tropics, decreases are related to small changes in the dominating chemical source terms (e.g. oxidation of $\mathrm{CH}_{3} \mathrm{OOH}$; a reduction of $\sim 3-5 \mathrm{Tg} \mathrm{CH}_{2} \mathrm{O} \mathrm{yr}^{-1}$ ). For the chemical destruction term, the relative insensitivity of the photolysis of $\mathrm{CH}_{2} \mathrm{O}$ to resolution (similar to $J_{\mathrm{O}_{3}}$; cf. Fig. S4) results in small net decreases in line with changes in the chemical production term.

Figure 11 compares monthly mean tropospheric profiles of $\mathrm{CH}_{2} \mathrm{O}$ measured during INTEX-B (Singh et al., 2009) with those from both TM5-MP simulations for March to May 2006. In general, there is a fair representation of the vertical gradient of $\mathrm{CH}_{2} \mathrm{O}$ by TM5-MP for all months shown, although surface mixing ratios are typically too high, suggesting that loss by deposition to the ocean is underestimated (potentially related to underestimations in surface area due to lack of 3-D wave structure) or that the chemical production term is too efficient. Moreover, there appears to be a missing (chemical) source term in the UTLS in TM5-MP, leading to a $\sim 30-50 \%(\sim 0.05 \mathrm{ppb})$ low bias above $600 \mathrm{hPa}$, i.e. there is 
Table 8. The tropospheric chemical budget for the $\mathrm{CH}_{2} \mathrm{O}$ given in $\mathrm{Tg} \mathrm{CH}_{2} \mathrm{O} \mathrm{yr}^{-1}$ during 2006 for the $1^{\circ} \times 1^{\circ}$ simulation. Percentage differences are shown against the corresponding $3^{\circ} \times 2^{\circ}$ simulation.

\begin{tabular}{lrrrrrrrr}
\hline Budget term & Global & $\%$ & $\mathrm{SH}$ & $\%$ & Tropics & $\%$ & $\mathrm{NH}$ & $\%$ \\
\hline $\mathrm{CH}_{2} \mathrm{O} \mathrm{CP}$ & 1919 & -1.1 & 147 & -0.3 & 1491 & -1.0 & 281 & -2.0 \\
$\mathrm{CH}_{2} \mathrm{O} \mathrm{CD}$ & 1739 & -1.6 & 134 & -0.5 & 1349 & -1.1 & 256 & -2.3 \\
$\mathrm{CH}_{2} \mathrm{O}$ dep. & 193 & 3.1 & 15 & 2.0 & 149 & 3.9 & 29 & - \\
\hline
\end{tabular}
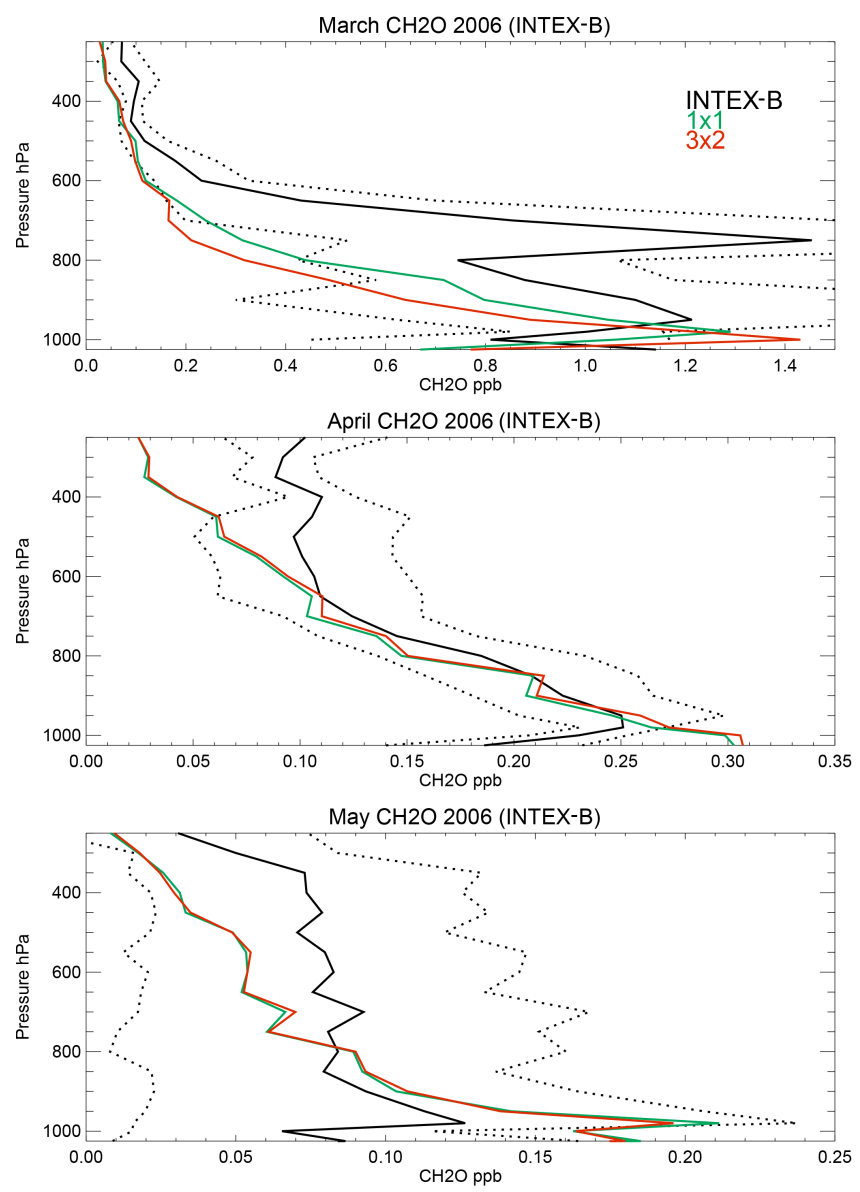

Figure 11. Comparisons of the vertical distribution of $\mathrm{CH}_{2} \mathrm{O}$ from both $3^{\circ} \times 2^{\circ}$ and $1^{\circ} \times 1^{\circ}$ simulations against measurements made as part of INTEX-B during 2006. The dotted line represents the $1 \sigma$ deviation in the mean of the measurements. For details on the exact location of the flights the reader is referred to Parrish et al. (2009).

no significant improvement to the underestimation in the $\mathrm{SH}$ $\mathrm{CH}_{2} \mathrm{O}$ column in TM5-MP when compared to mCB05 (Zeng et al., 2015). Comparing profiles shows that the changes in the vertical distribution of $\mathrm{CH}_{2} \mathrm{O}$ at $1^{\circ} \times 1^{\circ}$ are minimal in the chemical background compared to $3^{\circ} \times 2^{\circ}$, with the main differences originating from more efficient transport out of source regions (cf. March). These findings are further confirmed by the comparisons of TM5-MP against TexAQS II measurements for September and October 2006 (Fig. S18).

\section{Implications for tropospheric $\mathrm{SO}_{2}$ retrieval}

The global distributions of near-surface $\mathrm{SO}_{2}$ mixing ratios for both the $3^{\circ} \times 2^{\circ}$ and $1^{\circ} \times 1^{\circ}$ simulations are shown in the bottom panels of Fig. S17, where the distribution shows the land-based point sources as applied from the MACCity emission inventory. The high mixing ratios of $\mathrm{SO}_{2}$ correlate with the location of strong anthropogenic emission sources due to the relatively short atmospheric lifetime of $\mathrm{SO}_{2}$ (varying between $\sim 2$ days during winter and $\sim 19 \mathrm{~h}$ during summer; Lee et al., 2011), being rapidly oxidized to sulfate $\left(\mathrm{SO}_{4}^{=}\right)$. Although the regional distributions are similar, the $1^{\circ} \times 1^{\circ}$ simulation is able to differentiate point sources to a much better degree, which enhances the ability to derive more accurate emission fluxes. The in situ chemical production term of $\mathrm{SO}_{2}$ from the oxidation of oceanic di-methyl sulfide (DMS) is low; thus, there are very low $\mathrm{SO}_{2}$ mixing ratios in the chemical background. Also shown are the regions used for validating the $\mathrm{SO}_{2}$ surface concentrations and vertical profiles (insets in Fig. S17; see below).

In Fig. 12, we compare weekly $\left[\mathrm{SO}_{2}\right]$ for 2006 at a number of EMEP sites in Austria (AT02, forested), the Netherlands (NL09, rural), Great Britain (GB43, rural) and Spain (ES10, rural), with most sites being positioned away from strong point sources. For $\mathrm{SO}_{2}$ in Europe, the main emission source is anthropogenic (e.g. from the energy sector). High $\left[\mathrm{SO}_{2}\right]$ has been observed throughout the EMEP network in e.g. the Netherlands and Spain, which is significantly higher than that measured in central Europe (Tørseth et al., 2012). Although the measurement uncertainty is somewhat site-specific due to the different methodologies employed, it is typically around $\sim 1.3 \mu \mathrm{g} \mathrm{m}^{-3}$ (e.g. Hamad et al., 2010). Comparing weekly averages shows that for most sites shown there is a significant low bias at $3^{\circ} \times 2^{\circ}$, indicating inaccuracies in the MACC emission inventory and the effect of coarsening on the model resolution. At $1^{\circ} \times 1^{\circ}$ significant improvements occur in the correlations as a result of the better temporal distribution of anthropogenic emission sources.

Table 9 provides an overview of the seasonal biases for all of the EMEP sites that measure hourly $\left[\mathrm{SO}_{2}\right]$, with the biases calculated for the overpass time of tropOMI aggregated on a weekly basis. Improvements occur at $1^{\circ} \times 1^{\circ}$ for $\sim 20 \%$ of the sites during both seasons, with the majority $(\sim 50 \%)$ of sites showing no significant improvement $(<5 \%)$. In such instances the local $\left[\mathrm{SO}_{2}\right]$ is determined more by long-range 
Table 9. The seasonal mean biases of daily $\left[\mathrm{SO}_{2}\right]\left(\mu \mathrm{g} \mathrm{m}^{-3}\right)$ at 13:00 for DJF and JJA, when taking the difference between measurementsmodel values. Values are shown for both the $3^{\circ} \times 2^{\circ}$ and $1^{\circ} \times 1^{\circ}$ simulations. Those with differences $<5 \%$ are considered to exhibit no discernible change in the bias.

\begin{tabular}{lrrrrrr}
\hline EMEP station & Lat & Lon & DJF $3^{\circ} \times 2^{\circ}$ & DJF $1^{\circ} \times 1^{\circ}$ & JJA $3^{\circ} \times 2^{\circ}$ & JJA $1^{\circ} \times 1^{\circ}$ \\
\hline AT02 & 47.46 & 16.46 & -3.34 & -3.15 & -0.89 & -0.53 \\
AT05 & 46.40 & 12.58 & -0.42 & -0.41 & -0.14 & -0.14 \\
AT48 & 47.50 & 14.26 & -0.64 & -0.63 & -0.14 & -0.15 \\
CZ03 & 49.35 & 15.50 & -3.52 & 3.65 & -0.69 & 0.64 \\
ES07 & 37.14 & -3.32 & 1.22 & 0.73 & 0.38 & 0.31 \\
ES08 & 43.26 & -4.51 & -2.98 & -3.21 & -1.19 & -1.58 \\
ES09 & 41.16 & -3.80 & -0.62 & -0.61 & -0.42 & -0.42 \\
ES10 & 42.19 & 3.19 & 2.37 & 2.45 & 1.93 & 1.53 \\
ES11 & 38.28 & -6.55 & -0.63 & -0.61 & -0.70 & -0.70 \\
ES12 & 39.50 & -1.60 & -0.47 & -0.45 & -0.32 & -0.32 \\
ES13 & 41.17 & -5.52 & -0.81 & 2.71 & -0.78 & 0.55 \\
ES14 & 41.24 & 0.43 & -0.70 & -0.67 & -0.47 & -0.47 \\
ES15 & 39.31 & -4.21 & -0.40 & -0.37 & -0.45 & -0.46 \\
ES16 & 43.13 & -7.41 & -3.84 & -3.82 & -1.66 & -1.66 \\
GB37 & 52.30 & -3.11 & -2.92 & -2.91 & -1.72 & -1.72 \\
GB38 & 53.23 & -1.45 & 2.93 & 2.75 & 0.39 & 1.33 \\
GB43 & 51.14 & -4.42 & -1.49 & 4.77 & -2.03 & -0.63 \\
GB45 & 52.17 & -0.17 & 3.87 & 7.20 & 1.01 & 1.77 \\
GR01 & 38.22 & 23.50 & 1.70 & 2.77 & 0.74 & 1.50 \\
NL07 & 52.50 & 6.34 & 2.58 & -1.67 & 0.46 & -1.03 \\
NL08 & 52.70 & 5.12 & 1.77 & 1.56 & -0.14 & -0.30 \\
NL09 & 53.2 & 6.16 & 2.53 & 2.16 & 0.47 & 0.27 \\
\hline & & & & & & \\
\hline
\end{tabular}

transport (and is thus sensitive to wash-out) than a local emission source, where strong mitigation practises have been implemented in Europe over the last few decades reducing resident $\left[\mathrm{SO}_{2}\right]$ significantly (Tørseth et al., 2012). For some sites there is a notable increase in biases at $1^{\circ} \times 1^{\circ}(20 \%$ DJF, $25 \% \mathrm{JJA})$, indicating that overly strong local emission sources occur in the MACC inventories (e.g. ES13 and GR01). For others (e.g. ES08 and NL07) significantly low biases occur, suggesting the opposite problem.

Finally, for the vertical profiles, we make comparisons against monthly mean composites assembled from measurements taken during INTEX-B (Fig. S19) and TexAQS II (Fig. 13) as for the other trace gas species. For the more pristine locations there are typically low biases at $3^{\circ} \times 2^{\circ}$ for all months, especially at the surface during March, indicating a significant underestimation of the emission fluxes of $\mathrm{SO}_{2}$. Increasing to $1^{\circ} \times 1^{\circ}$ only provides an improved correlation for March, due to the transport in the FT being described better, as shown for $\mathrm{NO}_{2}$ in Fig. 7. For April, the comparison shows a significant underestimation in the column for both simulations, where corresponding comparisons of the vertical profiles of DMS, which acts as a key source of $\mathrm{SO}_{2}$ in the equatorial Pacific (Alonza Gray et al., 2011), agree quite well (not shown). This points to an appreciable biogenic source term that is currently missing from the inventories as proposed for organic nitrates (Williams et al., 2014). For May, again no significant improvement occurs at $1^{\circ} \times 1^{\circ}$, although both simulations capture the peak in $\mathrm{SO}_{2}$ mixing ratios at the top of the BL. More relevant for satellite-based retrievals is the observed column near strong anthropogenic source regions as shown in Fig. 13 over Texas during September and October 2006. Here a clear improvement occurs at $1^{\circ} \times 1^{\circ}$, with the low bias in the BL being reduced significantly, although the integrated column is still too low. Again this is due to the underestimation in the source emission fluxes in the anthropogenic emission inventory employed.

\section{Conclusions}

In this paper we have provided a comprehensive description of the high-resolution $1^{\circ} \times 1^{\circ}$ version of TM5, which is to be used for the purpose of providing a priori columns for the satellite retrieval of trace gas columns of $\mathrm{NO}_{2}, \mathrm{CH}_{2} \mathrm{O}$ and $\mathrm{SO}_{2}$. By performing identical simulations at a horizontal resolution of $3^{\circ} \times 2^{\circ}$ and $1^{\circ} \times 1^{\circ}$, and comparing the resulting global distributions of trace gas species, photolysis frequencies and chemical budget terms, we quantify and validate both the near-surface and vertical distributions for the evaluation year of 2006 .

Comparing the seasonal distribution in ${ }^{222} \mathrm{Rn}$ between resolutions, we show differences in the vertical distribution of up to $\pm 20 \%$ at the global scale, with significantly larger impacts for specific coastal regions and tropical oceans. In order 

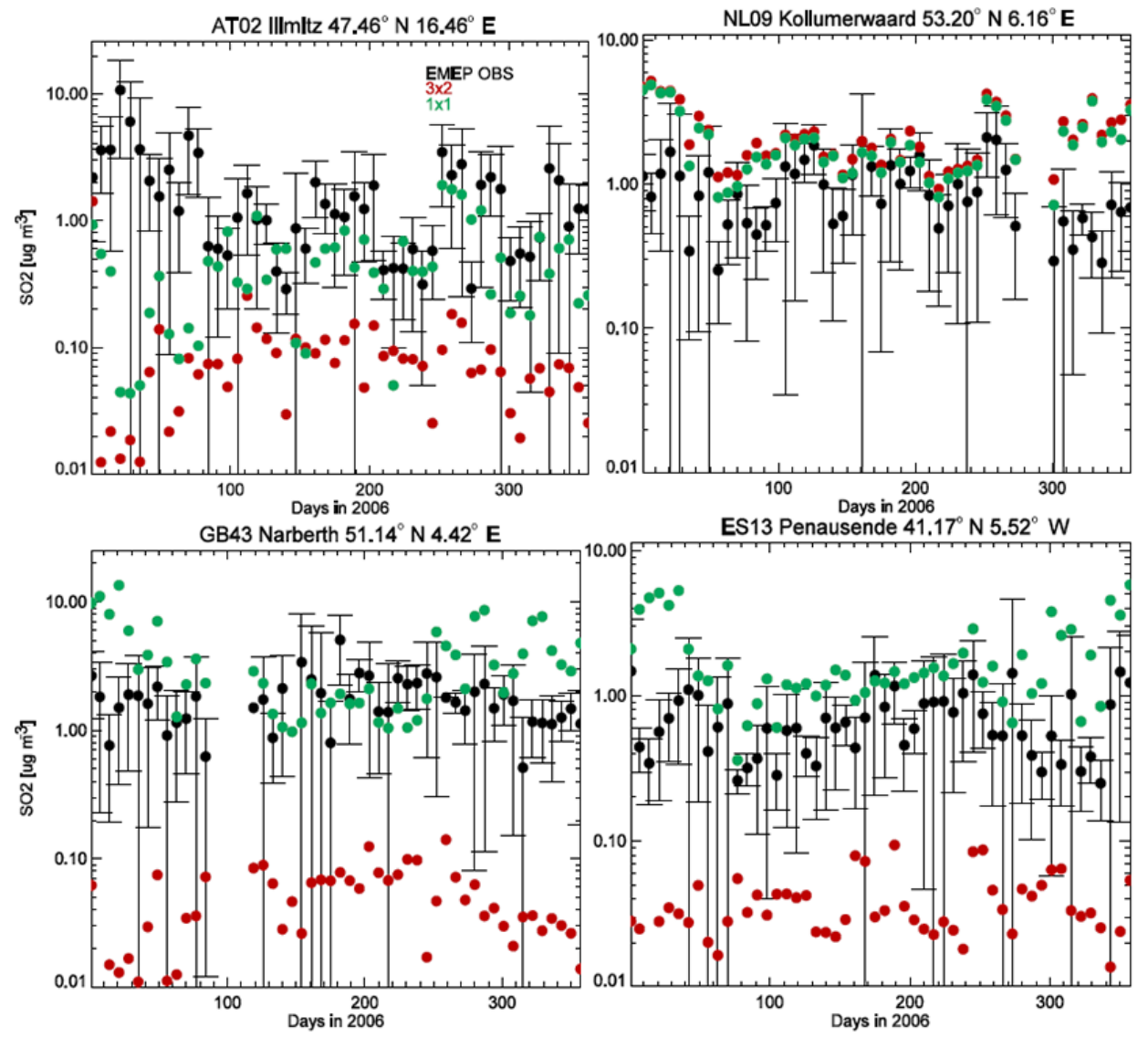

Figure 12. Comparison of weekly $\left[\mathrm{SO}_{2}\right]\left(\mu \mathrm{g} \mathrm{m}^{-3}\right)$ at 13:00 from both the $3^{\circ} \times 2^{\circ}$ and $1^{\circ} \times 1^{\circ}$ simulations at four selected EMEP sites for 2006. The selected sites shown are in Austria (top left), the Netherlands (top right), Great Britain (bottom left) and Spain (bottom right).

to assess the changes in convective activity above strong $\mathrm{NO}_{x}$ sources, we show that differences of between $\sim 2$ and $10 \%$ ( $\sim 10-20 \%)$ exist for the northern mid-latitudes (tropics) at higher resolution, with both weaker and stronger upwelling occurring depending on the region and the season. The magnitudes of the changes are site-specific, being affected by local orography. We have also made comparisons using a $1^{\circ} \times 1^{\circ}$ simulation applying the Tiedtke (1989) convection scheme, showing that ERA-Interim mass fluxes result in less transport of ${ }^{222} \mathrm{Rn}$ out of the boundary layer, where it has been shown that the use of ERA-Interim mass fluxes introduces inconclusive improvements in surface ${ }^{222} \mathrm{Rn}$ distributions (Koffi et al., 2016). For lightning $\mathrm{NO}_{x}$ there is a vertical re-distribution in the emission flux, with enhanced $\mathrm{NO}_{x}$ injected into the upper troposphere when using the ERAInterim mass fluxes.

Although the impact of resolution on daily photolysis rates may be appreciable, analysing global monthly mean $J_{\mathrm{O}_{3}}$ and $J_{\mathrm{NO}_{2}}$ surface values over a range of conditions shows that effects are limited to $\sim 2 \%$ and $\sim 5-10 \%$, respectively. One contributing factor to this rather muted impact is that the changes in surface albedo that occur at $1^{\circ} \times 1^{\circ}$ are largest at the poles during winter, which has no impact on photo-chemistry due to the absence of photolysing light (not shown). For cloud cover, a dominant term for determining total optical depth, there are significant increases at $1^{\circ} \times 1^{\circ}$ over the oceans, although this is generally related to instances of low photochemical activity. Examining the resulting changes in $J_{\mathrm{O}_{3}}$ and $J_{\mathrm{NO}_{2}}$ which occur throughout the tropospheric column reveals that significant differences of $>10 \%$ can occur at the top of the BL at tropical locations. Such modest changes associated with this dominant loss term result in the change in the integrated chemical budget terms for tropospheric $\mathrm{O}_{3}$ and $\mathrm{NO}_{2}$ being rather low.

Analysing the chemical budget terms for tropospheric $\mathrm{O}_{3}$ shows (i) a reduction in the stratosphere-troposphere exchange flux of $\sim 7 \%$ to $597 \mathrm{Tg} \mathrm{O}_{3} \mathrm{yr}^{-1}$, (ii) a repartitioning of the contribution from stratospheric downwelling in both the Northern and Southern hemispheres, (iii) no significant change in the tropospheric burden of $\mathrm{O}_{3}$ and (iv) modest changes in the integrated chemical production and destruction terms. Comparing simulated mixing ratios against surface measurements in Europe shows that the positive bias present in TM5 decreases by $\sim 20 \%$ at $1^{\circ} \times 1^{\circ}$ between 2 and $5 \mathrm{ppb}$ month $^{-1}$. This positive bias persists throughout the vertical column across diverse global regions regardless of 

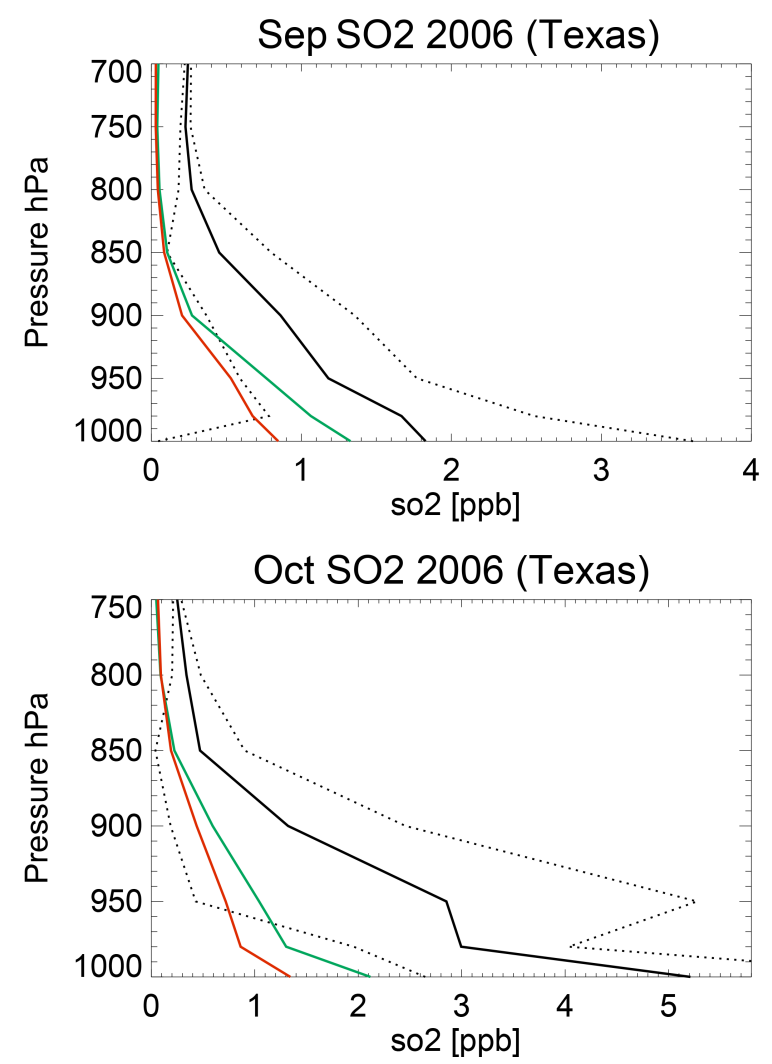

Figure 13. Comparisons of the monthly tropospheric $\mathrm{SO}_{2}$ profile assembled from data taken during September and October 2006 as part of TexAQS II. The $1 \sigma$ deviation of the mean derived from the measurements is shown as the dotted line. For details of the flight paths the reader is referred to Parrish et al. (2009).

the local $\mathrm{NO}_{x}$ emissions, although the vertical gradient in tropospheric $\mathrm{O}_{3}$ through the tropospheric column is captured quite well.

For $\mathrm{NO}$ and $\mathrm{NO}_{2}$ increasing horizontal resolution results in only modest differences in the zonal mean recycling terms and the loss of $\mathrm{O}_{3}$ by chemical titration. Comparisons against surface measurements in Europe show that there is a consistent negative bias in weekly [NO] of a few $\mu \mathrm{g} \mathrm{m}^{-3}$ associated with both overly high surface $\mathrm{O}_{3}$ (enhanced $\mathrm{NO}$ titration) and the inaccuracy of the $\mathrm{NO}_{x}$ emission inventories. For $\mathrm{NO}_{2}$, the biases in the weekly concentrations are larger and can be both positive and negative. Increasing horizontal resolution has little effect on reducing the NO biases, but results in improvements for $\mathrm{NO}_{2}$ at $\sim 35 \%$ of the available sites, with $\sim 45 \%$ of sites showing limited changes. Examining correlation coefficients shows that although there is typically a higher correlation at $1^{\circ} \times 1^{\circ}$, many sites still exhibit very low correlation or anti-correlation for some seasons. For the tropospheric column the improvement in the comparisons is only by a few percent, with a significant underestimation in both $\mathrm{NO}$ and $\mathrm{NO}_{2}$ throughout the tropospheric column. Analysing the $\mathrm{NO} / \mathrm{NO}_{2}$ ratio and comparing against obser- vations show that although partitioning is captured in the $\mathrm{BL}$, there is a significant overestimation in the upper troposphere.

Finally, for $\mathrm{CH}_{2} \mathrm{O}$ and $\mathrm{SO}_{2}$, which can also be retrieved from satellite measurements, the effect of increased resolution is rather modest due to compensating changes to the chemical budget terms. When compared against observations there is a persistent low bias for tropospheric $\mathrm{CH}_{2} \mathrm{O}$ due to missing production terms, especially in the free troposphere. $\mathrm{SO}_{2}$ comparison with surface observations in Europe shows lower biases at $20 \%$ of sites due to more accurate local emission fluxes, whereas for the majority of cases $(\sim 50 \%)$ there is no significant change. Comparing vertical profiles shows a significant underestimation in the tropospheric column likely associated with either missing precursors or an underestimation in the direct emission terms.

Future updates to TM5-MP will most likely focus on developing an online secondary organic aerosol scheme, tropospheric halogen chemistry and incorporating an updated isoprene oxidation scheme involving more intermediate species. It will also be applied in the context of an Earth system model (EC-EARTH) for allowing future studies concerning chemistry-climate feedbacks. When computing resources allow, more expensive simulations can be performed using the 60 vertical levels as defined in the ERA-Interim meteorological dataset, approximately doubling the resolution of the simulations presented here. An additional update to improve the STE would be to apply the second-order moments scheme (Prather, 1986), whose application has been shown to capture the seasonality and magnitude of STE exchange to a better degree (Bönisch et al., 2008). In terms of oxidative capacity, one means of reducing the tropospheric near-surface $\mathrm{O}_{3}$ mixing ratios would be to improve loss to land surfaces (Hardacre et al., 2010), although mixing ratios have been shown to be insensitive to the additional loss term to oceans, which is currently missing from many CTMs (Ganzeveld et al., 2009). Our comparisons of $\mathrm{CH}_{2} \mathrm{O}$ and $\mathrm{SO}_{2}$ show that there is a significant uncertainty of chemical processes that affect distributions in the pristine marine environment. For instance, the physical process of deposition seems to be under-represented, possibly due to an overly low surface area of the surface, i.e. the lack of a flat surface. The significant underestimates in $\mathrm{SO}_{2}$ suggest missing biogenic source terms; therefore, more understanding of biogenic emission terms is necessary.

\section{Code availability}

The TM5-MP code can be downloaded from the SVN server hosted at KNMI, the Netherlands. A request to generate a new user account for access can be made by e-mailing sager@knmi.nl. Any new user groups need to agree to the protocol set out for use, where it is expected that any developments are accessible to all users after publication of re- 
sults. Attendance at 9-monthly TM5 international meetings is encouraged to avoid duplicity and conflict of interests.

\section{The Supplement related to this article is available online at doi:10.5194/gmd-10-721-2017-supplement.}

Competing interests. The authors declare that they have no conflict of interest.

Acknowledgements. This research has been supported by FP7 project Quality Assurance for Essential Climate Variables (QA4ECV), no. 607405. We thank M. van Weele for processing the MSR2 stratospheric ozone data record used for constraining the overhead $\mathrm{O}_{3}$ field and T. P. C. van Noije for updating the $\mathrm{SO}_{x}$ emission estimates. We thank V. Huijnen for providing estimates on the heterogeneous uptake coefficients.

Edited by: F. O'Connor

Reviewed by: two anonymous referees

\section{References}

Aan de Brugh, J. M. J., Schaap, M., Vignati, E., Dentener, F., Kahnert, M., Sofiev, M., Huijnen, V., and Krol, M. C.: The European aerosol budget in 2006, Atmos. Chem. Phys., 11, 1117-1139, doi:10.5194/acp-11-1117-2011, 2011.

Aas, W., Hjellbrekke, A.-G., Schaug, J., and Solberg, S.: Data quality 1999, quality assurance and field comparisons, Kjeller, Norwegian Institute for Air Research, EMEP/CCC Report 6/2001, 2001.

Abbatt, J. P. D., Lee, A. K. Y., and Thornton, J. A.: Quantifying trace gas uptake to tropospheric aerosol: recent advances and remaining challenges, Chem. Soc. Rev., 41, 6555-6581, doi:10.1039/c2cs35052a, 2012.

Alonza Gray, B., Wang, Y., Gu, D., Bandy, A., Mauldin, L., Clarke, A., Alexander, B., and Davis, D. D.: Sources, transport, and sinks of $\mathrm{SO}_{2}$ over the equatorial Pacific during the Pacific Atmospheric Sulfur Experiment, J. Atmos. Chem., 68, 27-53, doi:10.1007/s10874-010-9177-7, 2011.

Atkinson, R., Baulch, D. L., Cox, R. A., Crowley, J. N., Hampson, R. F., Hynes, R. G., Jenkin, M. E., Rossi, M. J., and Troe, J.: Evaluated kinetic and photochemical data for atmospheric chemistry: Volume $\mathrm{I}-$ gas phase reactions of $\mathrm{O}_{x}, \mathrm{HO}_{x}, \mathrm{NO}_{x}$ and $\mathrm{SO}_{x}$ species, Atmos. Chem. Phys., 4, 1461-1738, doi:10.5194/acp-41461-2004, 2004.

Atkinson, R., Baulch, D. L., Cox, R. A., Crowley, J. N., Hampson, R. F., Hynes, R. G., Jenkin, M. E., Rossi, M. J., Troe, J., and IUPAC Subcommittee: Evaluated kinetic and photochemical data for atmospheric chemistry: Volume II - gas phase reactions of organic species, Atmos. Chem. Phys., 6, 3625-4055, doi:10.5194/acp-6-3625-2006, 2006.
Bândă, N., Krol, M., van Noije, T., van Weele, M., Williams, J. E., Le Sager, P., Niemeier, U., Thomason, L., and Röckmann, T.: The effect of stratospheric sulfur from Mount Pinatubo on tropospheric oxidizing capacity and methane, J. Geophys. Res.Atmos., 120, 1202-1220, doi:10.1002/2014JDO22137, 2015.

Boersma, K. F., Jacob, D. J., Eskes, H. J., Pinder, R. W., Wang, J., and van der A, R. J.: Intercomparison of SCIAMACHY and OMI tropospheric $\mathrm{NO}_{2}$ columns: observing the diurnal evolution of chemistry and emissions from space, J. Geophys. Res., 2, 1-14, doi:10.1029/2007JD008816, 2008.

Boersma, K. F., Eskes, H. J., Dirksen, R. J., van der A, R. J., Veefkind, J. P., Stammes, P., Huijnen, V., Kleipool, Q. L., Sneep, M., Claas, J., Leitão, J., Richter, A., Zhou, Y., and Brunner, D.: An improved tropospheric $\mathrm{NO}_{2}$ column retrieval algorithm for the Ozone Monitoring Instrument, Atmos. Meas. Tech., 4, 19051928, doi:10.5194/amt-4-1905-2011, 2011.

Bönisch, H., Hoor, P., Gurk, Ch., Feng, W., Chipperfield, M., Engel, A., and Bregman, B.: Model evaluation of $\mathrm{CO}_{2}$ and $\mathrm{SF}_{6}$ in the extratropical UT/LS region, J. Geophys. Res., 113, D06101, doi:10.1029/2007JD008829, 2008.

Bregman, B., Segers, A., Krol, M., Meijer, E., and van Velthoven, P.: On the use of mass-conserving wind fields in chemistry-transport models, Atmos. Chem. Phys., 3, 447-457, doi:10.5194/acp-3447-2003, 2003.

Browne, E. C., Perring, A. E., Wooldridge, P. J., Apel, E., Hall, S. R., Huey, L. G., Mao, J., Spencer, K. M., Clair, J. M. St., Weinheimer, A. J., Wisthaler, A., and Cohen, R. C.: Global and regional effects of the photochemistry of $\mathrm{CH}_{3} \mathrm{O}_{2} \mathrm{NO}_{2}$ : evidence from ARCTAS, Atmos. Chem. Phys., 11, 4209-4219, doi:10.5194/acp-11-4209-2011, 2011.

Carslaw, D. C. and Beevers, S. D.: Estimations of road vehicle primary $\mathrm{NO}_{2}$ exhaust emission frcations using monitoring data in London, Atmos. Environ., 39, 167-177, 2005.

Dee, D. P., Uppala, S. M., Simmons, A. J., Berrisford, P., Poli, P., Kobayashi, S., Andrae, U., Balmaseda, M. A., Balsamo, G., Bauer, P., Bechtold, P., Beljaars, A. C. M., van de Berg, L., Bidlot, J., Bormann, N., Delsol, C., Dragani, R., Fuentes, M., Geer, A. J., Haimberger, L., Healy, S. B., Hersbach, H., Hólm, E. V., Isaksen, L., Kållberg, P., Köhler, M., Matricardi, M., McNally, A. P., Monge-Sanz, B. M., Morcrette, J.-J., Park, B.-K., Peubey, C., de Rosnay, P., Tavolato, C., Thépaut, J.-N., and Vitart, F.: The ERA-Interim reanalysis: configuration and performance of the data assimilation system, Q. J. Roy. Meteor. Soc., 137, 553-597, 2011.

De Smedt, I., Müller, J.-F., Stavrakou, T., van der A, R., Eskes, H., and Van Roozendael, M.: Twelve years of global observations of formaldehyde in the troposphere using GOME and SCIAMACHY sensors, Atmos. Chem. Phys., 8, 4947-4963, doi:10.5194/acp-8-4947-2008, 2008.

Dunlea, E. J., Herndon, S. C., Nelson, D. D., Volkamer, R. M., San Martini, F., Sheehy, P. M., Zahniser, M. S., Shorter, J. H., Wormhoudt, J. C., Lamb, B. K., Allwine, E. J., Gaffney, J. S., Marley, N. A., Grutter, M., Marquez, C., Blanco, S., Cardenas, B., Retama, A., Ramos Villegas, C. R., Kolb, C. E., Molina, L. T., and Molina, M. J.: Evaluation of nitrogen dioxide chemiluminescence monitors in a polluted urban environment, Atmos. Chem. Phys., 7, 2691-2704, doi:10.5194/acp-7-2691-2007, 2007.

Dupuy, E., Urban, J., Ricaud, P., Le Flochmoën, E., Lautié, N., Murtagh, D., De La Noë, J., El Amraoui, L., Eriksson, P., Fork- 
man, P., Frisk, U., Jégou, F., Jiménez, C., and Olberg, M.: Stratomesospheric measurements of carbon monoxide with the Odin Sub-Millimetre Radiometer: Retrieval and first results, Geophys. Res. Letts., 31, L20101, doi:10.1029/2004GL020558, 2004.

Emmons, L. K., Walters, S., Hess, P. G., Lamarque, J.-F., Pfister, G. G., Fillmore, D., Granier, C., Guenther, A., Kinnison, D., Laepple, T., Orlando, J., Tie, X., Tyndall, G., Wiedinmyer, C., Baughcum, S. L., and Kloster, S.: Description and evaluation of the Model for Ozone and Related chemical Tracers, version 4 (MOZART-4), Geosci. Model Dev., 3, 43-67, doi:10.5194/gmd3-43-2010, 2010.

Evans, M. J. and Jacob, D. J.: Impact of new laboratory studies of $\mathrm{N}_{2} \mathrm{O}_{5}$ hydrolysis on global model budgets of tropospheric nitrogen oxides, ozone and OH, Geophys. Res. Lett., 32, L09813, doi:10.1029/2005GL022469, 2005.

Fioletov, V. E., McLinden, C. A., Krotkov, N., and Li, C.: Lifetimes and emissions of $\mathrm{SO}_{2}$ from point sources estimated from OMI, Geophys. Res. Letts., 42, 1969-1976, doi:10.1002/2015GL063148, 2015.

Fisher, J. A., Wilson, S. R., Zeng, G., Williams, J. E., Emmons, L. K., Langenfelds, R. L., Krummel, P. B., and Steele, L. P.: Seasonal changes in the tropospheric carbon monoxide profile over the remote Southern Hemisphere evaluated using multi-model simulations and aircraft observations, Atmos. Chem. Phys., 15, 3217-3239, doi:10.5194/acp-15-3217-2015, 2015.

Fortuin, J. P. F. and Kelder, H.: An ozone climatology based on ozonesonde and satellite measurements, J. Geophys. Res., 103, 31709-31734, 1998.

Ganzeveld, L., Helmig, D., Fairall, C. W., Hare, J., and Pozzer, A.: Atmosphere-ocean ozone exchange: A global modeling study of biogeochemical, atmospheric, and waterside turbulence dependencies, Global Biogeochem. Cy., 23, GB4021, doi:10.1029/2008GB003301, 2009.

Gonçalves, M., Dabdub, D., Chang, W. L., Jorba, O., and Baldasanoa, J. M.: Impact of HONO sources on the performance of mesoscale air quality models, Atmos. Environ., 54, 168-176, doi:10.1016/j.atmosenv.2012.02.079, 2012.

Gonzi, S., Palmer, P. I., Barkley, M., De Smedt, I., and Roozendael, M. V.: Biomass burning emission estimates inferred from satellite column measurements of HCHO: Sensitivity to co-emitted aerosol and injection height, Geophys. Res. Letts., 38, L14807, doi:10.1029/2011GL047890V, 2011.

Granier, C., Bessagnet, B., Bond, T., D’Angiola, A., Denier van der Gon, H., Frost, G. J., Heil, A., Kaiser, J. W., Kinne, S., Klimont, Z., Kloster, S.-F., Lamarque, J., Liousse, C., Masui, T., Meleux, F., Mieville, A., Ohara, T., Raut, J.-C., Riahi, K., Schultz, M. G., Smith, S. J., Thompson, A., van Aardenne, J., van der Werf, G. R., and van Vuuren, D. P.: Evolution of anthropogenic and biomass burning emissions of air pollutants at global and regional scales during the 1980-2010 period, Climate Change, 109, 163-190, doi:10.1007/s10584-011-0154-1, 2011.

Grooß, J.-U. and Russell III, J. M.: Technical note: A stratospheric climatology for $\mathrm{O}_{3}, \mathrm{H}_{2} \mathrm{O}, \mathrm{CH}_{4}, \mathrm{NO}_{x}, \mathrm{HCl}$ and $\mathrm{HF}$ derived from HALOE measurements, Atmos. Chem. Phys., 5, 2797-2807, doi:10.5194/acp-5-2797-2005, 2005.

Halmer, M. M., Schmincke, H.-U., and Graf, H.-F.: The annual volcanic gas input into the atmosphere, in particular into the stratosphere: a global data set for the past 100 years, J. Volcanol. Geoth. Res., 115, 511-528, 2002.
Hamed, A., Birmili, W., Joutsensaari, J., Mikkonen, S., Asmi, A., Wehner, B., Spindler, G., Jaatinen, A., Wiedensohler, A., Korhonen, H., Lehtinen, K. E. J., and Laaksonen, A.: Changes in the production rate of secondary aerosol particles in Central Europe in view of decreasing $\mathrm{SO}_{2}$ emissions between 1996 and 2006, Atmos. Chem. Phys., 10, 1071-1091, doi:10.5194/acp-10-10712010, 2010.

Hardacre, C., Wild, O., and Emberson, L.: An evaluation of ozone dry deposition in global scale chemistry climate models, Atmos. Chem. Phys., 15, 6419-6436, doi:10.5194/acp-15-64192015, 2015.

Hauglustaine, D. A., Balkanski, Y., and Schulz, M.: A global model simulation of present and future nitrate aerosols and their direct radiative forcing of climate, Atmos. Chem. Phys., 14, 1103111063, doi:10.5194/acp-14-11031-2014, 2014.

Heckel, A., Kim, S.-W., Frost, G. J., Richter, A., Trainer, M., and Burrows, J. P.: Influence of low spatial resolution a priori data on tropospheric $\mathrm{NO}_{2}$ satellite retrievals, Atmos. Meas. Tech., 4, 1805-1820, doi:10.5194/amt-4-1805-2011, 2011.

Huijnen, V., Williams, J., van Weele, M., van Noije, T., Krol, M., Dentener, F., Segers, A., Houweling, S., Peters, W., de Laat, J., Boersma, F., Bergamaschi, P., van Velthoven, P., Le Sager, P., Eskes, H., Alkemade, F., Scheele, R., Nédélec, P., and Pätz, H.-W.: The global chemistry transport model TM5: description and evaluation of the tropospheric chemistry version 3.0, Geosci. Model Dev., 3, 445-473, doi:10.5194/gmd-3-445-2010, 2010.

Holtslag, A. A. and Boville, B. A.: Local versus non-local boundary layer diffusion in a global climate model, J. Climate, 10, 18251842, 1993.

Huijnen, V., Williams, J. E., and Flemming, J.: Modeling global impacts of heterogeneous loss of $\mathrm{HO}_{2}$ on cloud droplets, ice particles and aerosols, Atmos. Chem. Phys. Discuss., 14, 8575-8632, doi:10.5194/acpd-14-8575-2014, 2014.

Jacob, D. J., Prather, M. J., Rasch, P. J., Shia, R. L., Balkanski, Y. J., Beagley, S. R., Bergmann, D. J., Blackshear, W. T., Brown, M., Chiba, M., Chipperfield, M. P., de Grandpré, J., Dignon, J. E., Feichter, J., Genthon, C., W. L. Grose, W. L., Kasibhatla, P. S., Köhler, I., Kritz, M. A., Law, K., Penner, J. E., Ramonet, M., Reeves, C. E., Rotman, D. A., Stockwell, D. Z., Van Velthoven, P. F. J., Verver, G., Wild, O., Yang, H., and Zimmermann, P.: Evaluation and intercomparison of global atmospheric transport models using ${ }^{222} \mathrm{Rn}$ and other short-lived tracers, J. Geophys. Res., 102, 5953-5970, doi:10.1029/96JD02955, 1997.

Jacob, J. D.: Heterogeneous chemistry and tropospheric ozone, Atmos. Environ., 34, 2131-2159, 2000.

Jégou, F., Urban, J., de La Noë, J., Ricaud, P., Le Flochmoën, E., Murtagh, D. P., Eriksson, P., Jones, A., Petelina, S., Llewellyn, E. J., Lloyd, N. D., Haley, C., Lumpe, J., Randall, C., Bevilacqua, R. M., Catoire, V., Huret, N., Berthet, G., Renard, J. B., Strong, K., Davies, J., Mc Elroy, C. T., Goutail, F., and Pommereau, J. P.: Technical Note: Validation of Odin/SMR limb observations of ozone, comparisons with OSIRIS, POAM III, ground-based and balloon-borne instruments, Atmos. Chem. Phys., 8, 3385-3409, doi:10.5194/acp-8-3385-2008, 2008.

Kim, S.-W., McKeen, S. A., Frost, G. J., Lee, S.-H., Trainer, M., Richter, A., Angevine, W. M., Atlas, E., Bianco, L., Boersma, K. F., Brioude, J., Burrows, J. P., de Gouw, J., Fried, A., Gleason, J., Hilboll, A., Mellqvist, J., Peischl, J., Richter, D., Rivera, C., Ryerson, T., te Lintel Hekkert, S., Walega, J., Warneke, C., Weib- 
ring, P., and Williams, E.: Evaluations of $\mathrm{NO}_{x}$ and highly reactive VOC emission inventories in Texas and their implications for ozone plume simulations during the Texas Air Quality Study 2006, Atmos. Chem. Phys., 11, 11361-11386, doi:10.5194/acp11-11361-2011, 2011.

Koffi, E. N., Bergamaschi, P., Karstens, U., Krol, M., Segers, A., Schmidt, M., Levin, I., Vermeulen, A. T., Fisher, R. E., Kazan, V., Klein Baltink, H., Lowry, D., Manca, G., Meijer, H. A. J., Moncrieff, J., Pal, S., Ramonet, M., Scheeren, H. A., and Williams, A. G.: Evaluation of the boundary layer dynamics of the TM5 model over Europe, Geosci. Model Dev., 9, 3137-3160, doi:10.5194/gmd-9-3137-2016, 2016.

Krol, M., Houweling, S., Bregman, B., van den Broek, M., Segers, A., van Velthoven, P., Peters, W., Dentener, F., and Bergamaschi, P.: The two-way nested global chemistry-transport zoom model TM5: algorithm and applications, Atmos. Chem. Phys., 5, 417432, doi:10.5194/acp-5-417-2005, 2005.

Lawrence, M. G. and Crutzen, P. J.: The impact of cloud particle gravitational settling on soluble trace gas distributions, Tellus, 50B, 263-289, 1998.

Lee, C., Martin, R. V., van Donkelaar, A., Lee, H., Dickerson, R. R., Hains, J. C., Krotkov, N., Richter, A., Vinnikov, K. and Schwab, J. J.: $\mathrm{SO}_{2}$ emissions and lifetimes: Estimates from inverse modeling using in situ and global, space-based (SCIAMACHY and OMI) observations, J. Geophys. Res., 116, D06304, doi:10.1029/2010JD014758, 2011.

Lelieveld, J., Peters, W., Dentener, F. J., and Krol, M. C.: Stability of tropospheric hydroxyl chemistry, J. Geophys. Res., 107, 4715, doi:10.1029/2002JD002272, 2002.

Lin, J.-T., Martin, R. V., Boersma, K. F., Sneep, M., Stammes, P., Spurr, R., Wang, P., Van Roozendael, M., Clémer, K., and Irie, H.: Retrieving tropospheric nitrogen dioxide from the Ozone Monitoring Instrument: effects of aerosols, surface reflectance anisotropy, and vertical profile of nitrogen dioxide, Atmos. Chem. Phys., 14, 1441-1461, doi:10.5194/acp-14-1441-2014, 2014.

Louis, J. F.: A parametric model of vertical eddy fluxes in the atmosphere, Bound.-Lay. Meteorol., 17, 187-202, 1979.

Marais, E. A., Jacob, D. J., Kurosu, T. P., Chance, K., Murphy, J. G., Reeves, C., Mills, G., Casadio, S., Millet, D. B., Barkley, M. P., Paulot, F., and Mao, J.: Isoprene emissions in Africa inferred from OMI observations of formaldehyde columns, Atmos. Chem. Phys., 12, 6219-6235, doi:10.5194/acp-12-62192012, 2012.

Martin, G. M., Johnson, D. W., and Spice, A.: The measurement and parameterization of effective radius of droplets in warm stratocumulus clouds, J. Atmos. Sci., 51, 1823-1842, 1994.

Meijer, E. W., van Velthoven, P. F. J., Brunner, D. W., Huntrieser, H., and Kelder, H.: Improvement and evaluation of the parameterisation of nitrogen oxide production by lightning, Phys. Chem. Earth, 26, 557-583, 2001.

Meloen, J., Siegmund, P., van Velthoven, P., Kelder, H., Sprenger, M., Wernli, H., Kentarchos, A., Roelofs, G., Feichter, J., Land, C., Forster, C., James, P., Stohl, A., Collins, W., and Cristofanelli, P.: Stratosphere-troposphere exchange: A model and method intercomparison, J. Geophys. Res., 108, 8256, doi:10.1029/2002JD002274, 2002.
Metzger, S., Dentener, F., Pandis, S., and Lelieveld, J.: Gas/aerosol partitioning: 1. A computationally efficient model, J. Geophys. Res., 107, doi:10.1029/2001JD001102, 2002.

Möllner, A. K., Valluvadasan, S., Feng, L. Sprague, M. K., Okumura, M., Milligan, D. B., Bloss, W. J., Sander, S. P., Martien, P. T., Harley, R. A., McCoy, A. B., and Carter, W. P. L.: Rate of Gas Phase Association of Hydroxyl Radical and Nitrogen Dioxide, Science, 330, 646-649, doi:10.1126/science.1193030, 2010.

Olsen, S. C., McLinden, C. A., and Prather, M. J.: Stratospheric $\mathrm{N}_{2} \mathrm{O}-\mathrm{NO}_{y}$ system: Testing uncertainties in a three-dimensional framework, J. Geophys. Res., 106, 28771-28784, 2001.

Olszyna, K. J., Bailey, E. M., Simonaitis, R., and Meagher, J. F.: $\mathrm{O}_{3}$ and $\mathrm{NO}_{y}$ relationships at a rural site, 99, 14557-14563, J. Geophys. Res., doi:10.1029/94JD00739, 1994.

Palmer, P. I., Abbot, D. S., Fu, T.-M., Jacob, D. J., Chance, K., Kurosu, P., Guenther, A., Wiedinmyer, C., Stanton, J. C., Pilling, M. J., Pressley, S. N., Lamb, B., and Sumner, A. L.: Quantifying the seasonal and interannual variability of North American isoprene emissions using satellite observations of the formaldehyde column, J. Geophys. Res., 111, D12315, doi:10.1029/2005JD006689, 2006.

Parrish, D. D., Allen, D. T., Bates, T. S., Estes, M., Fehsenfeld, F. C., Feingold, G., Ferrare, R., Hardesty, R. M., Meagher, J. F., Nielsen-Gammon, J. W., Pierce, R. B., Ryerson, T. B., Seinfeld, J. H., and Williams, E. J.: Overview of the Second Texas Air Quality Study (TexAQS II) and the Gulf of Mexico Atmospheric Composition and Climate study (GoMACCS), J. Geophys. Res., 114, D00F13, doi:10.1029/2009JD011842, 2009.

Phillips, G. J., Makkonen, U., Schuster, G., Sobanski, N., Hakola, H., and Crowley, J. N.: The detection of nocturnal $\mathrm{N}_{2} \mathrm{O}_{5}$ as $\mathrm{HNO}_{3}$ by alkali- and aqueous-denuder techniques, Atmos. Meas. Tech., 6, 231-237, doi:10.5194/amt-6-231-2013, 2013.

Pope, R. J., Chipperfield, M. P., Savage, N. H., Ordóñez, C., Neal, L. S., Lee, L. A., Dhomse, S. S., Richards, N. A. D., and Keslake, T. D.: Evaluation of a regional air quality model using satellite column $\mathrm{NO}_{2}$ : treatment of observation errors and model boundary conditions and emissions, Atmos. Chem. Phys., 15, 5611-5626, doi:10.5194/acp-15-5611-2015, 2015.

Prather, M. J.: Numerical advection by conservation of secondorder moments, J. Geophys. Res., 91, 6671-6681, 1986.

Russell, A. R., Perring, A. E., Valin, L. C., Bucsela, E. J., Browne, E. C., Wooldridge, P. J., and Cohen, R. C.: A high spatial resolution retrieval of $\mathrm{NO}_{2}$ column densities from OMI: method and evaluation, Atmos. Chem. Phys., 11, 8543-8554, doi:10.5194/acp-11-8543-2011, 2011.

Sander, S. P., Abbatt, J. R., Burkholder, J. B., Friedl, R. R., Golden, D. M., Huie, R. E., Kolb, C. E., Kurylo, G., Moortgat, K., Orkin, V. L., and Wine, P. H.: Chemical kinetics and Photochemical Data for Use in Atmospheric studies, Evaluation No.17, JPL Publication 10-6, Jet Propulsion Laboratory, Pasadena, available at:http://jpldataeval.jpl.nasa.gov (last access: 26 February 2016), 2011.

Schery, S. D.: Progress on Global $\mathrm{Rn}^{222}$ Flux Maps and Recommendations for Future Research, in: 1st International Expert Meeting on Sources and Measurements of Natural Radionuclides Applied to Climate and Air Quality Studies (Gif-sur-Yvette, France, June 2003), edited by: Barrie, L. A. and Lee, H. N., WMO TD 1201, Gif-sur-Yvette, France, 43-47, 2004. 
Schwartz, S. E.: Mass-transport considerations pertinent to aqueous-phase reactions of gases in liquid-water clouds, in: Chemistry of Multiphase Atmospheric Systems, edited by: Jaechske, W., Springer, Heidelberg, 415-471, 1986.

Seltzer, K. M., Vizuete, W., and Henderson, B. H.: Evaluation of updated nitric acid chemistry on ozone precursors and radiative effects, Atmos. Chem. Phys., 15, 5973-5986, doi:10.5194/acp15-5973-2015, 2015.

Shettle, E. P. and Fenn, R. W.: Models for the aerosols of the lower atmosphere and the effects of the humidity variations on their optical properties, Environ. Res. Paper, 676, AFGL-TR-79-0114, 91 pp., 1979.

Sindelarova, K., Granier, C., Bouarar, I., Guenther, A., Tilmes, S., Stavrakou, T., Müller, J.-F., Kuhn, U., Stefani, P., and Knorr, W.: Global data set of biogenic VOC emissions calculated by the MEGAN model over the last 30 years, Atmos. Chem. Phys., 14, 9317-9341, doi:10.5194/acp-14-9317-2014, 2014.

Singh, H. B., Brune, W. H., Crawford, J. H., Flocke, F., and Jacob, D. J.: Chemistry and transport of pollution over the Gulf of Mexico and the Pacific: spring 2006 INTEX-B campaign overview and first results, Atmos. Chem. Phys., 9, 2301-2318, doi:10.5194/acp-9-2301-2009, 2009.

Stavrakou, T., Müller, J.-F., De Smedt, I., Van Roozendael, M., van der Werf, G. R., Giglio, L., and Guenther, A.: Global emissions of non-methane hydrocarbons deduced from SCIAMACHY formaldehyde columns through 2003-2006, Atmos. Chem. Phys., 9, 3663-3679, doi:10.5194/acp-9-3663-2009, 2009.

Steinbacher, M., Zellweger, C., Schwarzenbach, B., Bugmann, S., Buchmann, B., Ordónez, C., Prevot, A. S. H., and Hueglin, C.: Nitrogen oxides measurements at rural sites in Switzerland: bias of conventional measurement techniques, J. Geophys. Res., 112, D11307, doi:10.1029/2006JD007971, 2007.

Stevenson, D. S., Dentener, F. J., Schultz, M. G., Ellingsen, K., van Noije, T. P. C., Wild, O., Zeng, G., Amann, M., Atherton, M., Bell, N., Bergmann, D. J., Bey, I., Bulter, T., Cofala, J., Collins, W. J., Derwent, R. G., Doherty, R. M., Drevet, J., Eskes, H. J., Fiore, A. M., Gauss, M., Hauglustaine, D. A., Horowitz, L. W., Isaksen, I. S. A., Krol, M. C., Lamarque, J.F., Lawrence, M. G., Montanaro, V., Müller, J. F., Pitari, G., Prather, M. J., Pyle, J. A., Rast, S., Rodriguez, J. M., Sanderson, M. G., Savage, N. H., Shindell, D. T., Strahan, S. E., Sudo, K., and Szopa, S.: Multimodel ensemble simulations of presentday and near future tropospheric ozone, J. Geophys. Res., 111, D08301, doi:10.1029/2005JD006338, 2006.

Sutton, R. T., Dong, B., and Gregory, J. M.: Land/sea warming ratio in response to climate change: IPCC AR4 model results and comparison with observations, Geophys. Res. Letts., 34, L02701, doi:10.1029/2006GL028164, 2007.

Tang, Q., Prather, M. J., and Hsu, J.: Stratosphere-troposphere exchange ozone flux related to deep convection, Geophys. Res. Letts., 38, L03806, doi:10.1029/2010GL046039, 2011.

Thouret, V., Marenco, A., Logan, J. A., Nédélec, P., and Grouhel, C.: Comparisons of ozone measurements from the MOZAIC airborne program and the ozone sounding network at eight locations, J. Geophys. Res., 103, 25695-25720, 1998.

Tiedtke, M.: A comprehensive mass flux scheme for cumulus parameterization in large-scale models, Mon. Weather. Rev., 117, 1779-1800, 1989.
Tørseth, K., Aas, W., Breivik, K., Fjæraa, A. M., Fiebig, M., Hjellbrekke, A. G., Lund Myhre, C., Solberg, S., and Yttri, K. E.: Introduction to the European Monitoring and Evaluation Programme (EMEP) and observed atmospheric composition change during 1972-2009, Atmos. Chem. Phys., 12, 5447-5481, doi:10.5194/acp-12-5447-2012, 2012.

Urban, J., Pommier, M., Murtagh, D. P., Santee, M. L. and Orsolini, Y. J.: Nitric acid in the stratosphere based on Odin observations from 2001 to 2009 - Part 1: A global climatology, Atmos. Chem. Phys., 9, 7031-7044, doi:10.5194/acp-9-7031-2009, 2009.

Valks, P., Pinardi, G., Richter, A., Lambert, J.-C., Hao, N., Loyola, D., Van Roozendael, M., and Emmadi, S.: Operational total and tropospheric $\mathrm{NO}_{2}$ column retrieval for GOME-2, Atmos. Meas. Tech., 4, 1491-1514, doi:10.5194/amt-4-1491-2011, 2011.

van $\operatorname{der}$ A, R. J., Allaart, M. A. F., and Eskes, H. J.: Multi sensor reanalysis of total ozone, Atmos. Chem. Phys., 10, 11277-11294, doi:10.5194/acp-10-11277-2010, 2010.

van der Werf, G. R., Randerson, J. T., Giglio, L., Collatz, G. J., Mu, M., Kasibhatla, P. S., Morton, D. C., DeFries, R. S., Jin, Y., and van Leeuwen, T. T.: Global fire emissions and the contribution of deforestation, savanna, forest, agricultural, and peat fires (19972009), Atmos. Chem. Phys., 10, 11707-11735, doi:10.5194/acp10-11707-2010, 2010.

van Geffen, J. H. G. M., Boersma, K. F., Eskes, H. J., Maasakkers, J. D., and Veefkind, J. P.: TROPOMI Algorithm Theoretical Basis Document (ATBD) tropospheric and total $\mathrm{NO}_{2}$, S5P-KNMI-L20005-RP, 56 pp., 2016.

Veefkind, J. P., Aben, I., McMullan, K., Förster, H., de Vries, J., Otter, G., Claas, J., Eskes, H. J., de Haan, J. F., Kleipool, Q., van Weele, M., Hasekamp, O., Hoogeveen, R., Landgraf, J., Snel, R., Tol, P., Ingmann, P., Voors, R., Kruizinga, B., Vink, R., Visser, H., and Levelt, P. F.: TROPOMI on the ESA Sentinel-5 Precursor: A GMES mission for global observations of the atmospheric composition for climate, air quality and ozone layer applications, Remote. Sens. Environ., 120, 70-83, doi:10.1016/j.rse.2011.09.027, 2012.

Verstraeten, W. V., Neu, J. L., Williams, J. E., Bowman, K. W., and Worden, J. R.: Rapid increases in tropospheric ozone production and export from China, Nat. Geosci., 8, 690-695, doi:10.1038/ngeo2493, 2015.

Vinken, G. C. M., Boersma, K. F., Jacob, D. J., and Meijer, E. W.: Accounting for non-linear chemistry of ship plumes in the GEOS-Chem global chemistry transport model, Atmos. Chem. Phys., 11, 11707-11722, doi:10.5194/acp-11-11707-2011, 2011.

Vinken, G. C. M., Boersma, K. F., Maasakkers, J. D., Adon, M., and Martin, R. V.: Worldwide biogenic soil $\mathrm{NO}_{x}$ emissions inferred from $\mathrm{OMI} \mathrm{NO}_{2}$ observations, Atmos. Chem. Phys., 14, 10363 10381, doi:10.5194/acp-14-10363-2014, 2014.

Vogelezang, D. H. P. and Holtslag, A. A. M.: Evaluation and model impacts of alternative boundary-layer height formulations, Bound.-Lay. Meteorol., 81, 245-269, 1996.

von Kuhlmann, R. and Lawrence, M. G.: The impact of ice uptake of nitric acid on atmospheric chemistry, Atmos. Chem. Phys., 6, 225-235, doi:10.5194/acp-6-225-2006, 2006.

Wild, O. and Prather, M. J.: Global tropospheric ozone modeling: Quantifying errors due to grid resolution, J. Geophys. Res., 111, D11305, doi:10.1029/2005JD006605, 2006.

Williams, J. E., Strunk, A., Huijnen, V., and van Weele, M.: The application of the Modified Band Approach for the calcula- 
tion of on-line photodissociation rate constants in TM5: implications for oxidative capacity, Geosci. Model Dev., 5, 15-35, doi:10.5194/gmd-5-15-2012, 2012.

Williams, J. E., van Velthoven, P. F. J., and Brenninkmeijer, C. A. M.: Quantifying the uncertainty in simulating global tropospheric composition due to the variability in global emission estimates of Biogenic Volatile Organic Compounds, Atmos. Chem. Phys., 13, 2857-2891, doi:10.5194/acp-13-2857-2013, 2013.

Williams, J. E., Le Bras, G., Kukui, A., Ziereis, H., and Brenninkmeijer, C. A. M.: The impact of the chemical production of methyl nitrate from the $\mathrm{NO}+\mathrm{CH}_{3} \mathrm{O}_{2}$ reaction on the global distributions of alkyl nitrates, nitrogen oxides and tropospheric ozone: a global modelling study, Atmos. Chem. Phys., 14, 2363 2382, doi:10.5194/acp-14-2363-2014, 2014.

Worden, J., Liu, X., Bowman, K., Chance, K., Beer, R., Eldering, A., Gunson, M., and Worden, H.: Improved tropospheric ozone profile retrievals using OMI and TES radiances, Geophys. Res. Lett., 34, L01809, doi:10.1029/2006GL027806, 2007.

Yamaji, K., Ikeda, K., Irie, H., Kurokawa, J., and Ohara, T.: Influence of model grid resolution on $\mathrm{NO}_{2}$ vertical column densities over East Asia, J. Air. Waste Manage., 64, 436-444, 2014.

Yarwood, G., Rao, S., Yocke, M., and Whitten, G.: Updates to the carbon bond chemical mechanism: CB05, Final report to the US EPA, EPA Report Number: RT-0400675, available at: www.camx.com (last access: 15 January 2014), 2005.

Zdunkowski, W. G., Welsch, R. M., and Kord, G. J.: An investigation of the structure of typical 2-stream methods for the calculation of solar fluxes and heating rates in clouds, Contributions to Atmospheric Physics, 53, 215-238, 1980.
Zeng, G., Williams, J. E., Fisher, J. A., Emmons, L. K., Jones, N. B., Morgenstern, O., Robinson, J., Smale, D., Paton-Walsh, C., and Griffith, D. W. T.: Multi-model simulation of CO and HCHO in the Southern Hemisphere: comparison with observations and impact of biogenic emissions, Atmos. Chem. Phys., 15, 7217 7245, doi:10.5194/acp-15-7217-2015, 2015.

Zhang, K., Feichter, J., Kazil, J., Wan, H., Zhuo, W., Griffiths, A. D., Sartorius, H., Zahorowski, W., Ramonet, M., Schmidt, M., Yver, C., Neubert, R. E. M., and Brunke, E.-G.: Radon activity in the lower troposphere and its impact on ionization rate: a global estimate using different radon emissions, Atmos. Chem. Phys., 11, 7817-7838, doi:10.5194/acp-11-7817-2011, 2011.

Zhou, Y., Brunner, D., Hueglin, C., Henne, S., and Staehelin, J.: Changes in OMI tropospheric $\mathrm{NO}_{2}$ columns over Europe from 2004 to 2009 and the influence of meteorological variability, Atmos. Environ., 46, 482-495, 2012.

Zyrichidou, I., Soukouli, M. E., Balis, D., Markakis, K., Poupkou, A., Katragkou, E., Kioutsioukis, I., Melas, D., Boersma, K. F., and van Roozendael, M.: Identification of surface $\mathrm{NO}_{x}$ emission sources on a regional scale using $\mathrm{OMI} \mathrm{NO}_{2}$, Atmso. Environ. 101, 82-93, 2015. 